Arthur Antonio TAVARes Moreira Barbosa

\title{
A COMPETÊNCIA DO MUNICÍPIO PARA LEGISLAR SOBRE MEIO AMBIENTE
}

\author{
DisSERTAÇÃo DE MESTRADO
}

OrIENTAdora: Professora AsSOCIADA ANA MARIA DE OLIVEIRA NuSDEO

UNIVERSIDADE DE SÃO PAULO

FACULDADE DE DIREITO

SÃO PAULO - 2013 
ARTHur ANTONio TAVARES MoreIRA BARbosa

\section{A COMPETÊNCIA DO MUNICÍPIO PARA}

\section{LEGISLAR SOBRE MEIO AMBIENTE}

Dissertação apresentada à Faculdade de Direito da Universidade de São Paulo como requisito para a obtenção do Título de Mestre, sob orientação da Professora Associada Ana Maria de Oliveira Nusdeo.

UNIVERSIDADE DE SÃO PAULO

FACULDADE DE DIREITO

SÃO PAULO - 2013 
Banca Examinadora 
À minha filha, que virá ao mundo no próximo verão. 


\section{AGRADECIMENTOS}

À Professora Ana Maria de Oliveira Nusdeo, pela valorosa orientação, que em muito contribuiu para o desenvolvimento desta dissertação, assim como pelo exemplo de pessoa, dentro e fora das salas de aula, que em muito serviu de inspiração para meu aprimoramento pessoal, acadêmico e profissional.

Aos Professores Gilberto Passos de Freitas e Fernando Dias Menezes de Almeida, pelas iluminadas sugestões e considerações que enriqueceram este trabalho.

Aos Drs. Gilberto Leme Marcos Garcia e José Eduardo Ismael Lutti, que, no dia a dia da Promotoria do Meio Ambiente, muito me ensinaram, incentivando decisivamente minha dedicação à tutela ambiental.

Aos meus pais, Severino Antonio Moreira Barbosa e Katia Tavares da Silva, que desde cedo me ensinaram a importância da busca do conhecimento.

À Nathalia Lima Feitosa Lopes, pelo carinho demonstrado diariamente em todos esses anos.

Aos irmãos Severino, Antonio Pedro, Ana e aos amigos, pela felicidade da convivência. 


\section{RESUMO}

O presente trabalho visa à realização de um estudo sobre a possibilidade de os Municípios editarem leis aumentando a proteção ambiental em seu território, assim como os eventuais limites de referida atuação. Este estudo inicia-se com a análise da repartição de competências, notadamente sobre os poderes atribuídos aos Municípios pela Constituição Federal de 1988. O ente municipal recebeu deveres e competências mais abrangentes e, por estar mais próximo dos interesses dos cidadãos, precisa utilizar-se dessas competências para cumprir os deveres que lhe são impostos, especialmente no artigo 225 da Carta Magna. A edição de leis ambientalmente mais protetivas pelos Municípios acabou por ser questionada no Poder Judiciário, em razão da alegada falta de competência deste ente para a edição das referidas leis. Assim, multiplicaram-se nos últimos anos as Ações Diretas de Inconstitucionalidade contra a edição das leis municipais que buscavam proteger o meio ambiente local. Neste trabalho serão analisados alguns casos que afetam mais diretamente a população e que têm gerado debates mais profundos na doutrina e jurisprudência, especialmente no Tribunal de Justiça de São Paulo e no Supremo Tribunal Federal. Ao final, a partir da análise de cada caso concreto tratado, em diálogo com o refencial teórico, poder-se-á verificar as possibilidades da atuação do Município na edição de referidas leis ambientais, assim como os limites desta atuação frente à existência da legislação estadual e nacional.

Palavras-chave: Direito Ambiental - Competência Legislativa - Município 


\begin{abstract}
This paper is intended to conduct a study on the possibility of local government authorities to edit laws aiming to increase environmental protection within their relevant territories, as well as to rule any limits to such extent. The present study begins with the analysis of the allocation of competent jurisdiction, notably with respect to the powers granted to Municipalities pursuant to the Brazilian Federal Constitution of 1988. The local government authority was bestowed more comprehensive duties and jurisdiction and, precisely for the fact that it is closer to citizens' interest, it must avail itself from such jurisdiction so as to fulfill the duties imposed upon it, particularly those under Section 225 of the Brazilian Federal Constitution. The enactment of more protective environmental laws by Municipalities was challenged in courts on the grounds of alleged lack of jurisdiction on the part of Municipalities for purposes of the enactment of such laws. Hence, for the past years several suits challenging the enactment of municipal laws on local environment protection were filed. This paper addresses some of the cases that most directly affect population and which have given rise to heated debate on legal books of authority and case law, particularly in the Court of Appeals of the State of São Paulo and the Federal Supreme Court. As a final point, from the analysis of each case addressed herein, one shall be able to infer to which extent a certain Municipality is entitled to interfere in the enactment of these environmental laws, as well as the limits of the interference thereon vis-à-vis Brazilian state and federal legislation.
\end{abstract}

Keywords: Environmental Law - Legislative Authority - Municipality 


\section{SUMÁRIO}

Introdução. 10

Capítulo 1 - A adoção do modelo federativo e a repartição de competência na Constituição Federal de 1988

1.1. Da organização do Estado..................................................................14

1.2 Breve histórico do federalismo.........................................................19

1.3 A Federação brasileira.....................................................................20

$1.4 \mathrm{O}$ conceito de competência no direito pátrio..........................................22

1.5 Classificaçãa das competências...............................................................23

1.5.1 Competência administrativa...................................................23

1.5.1.1 Competência administrativa exclusiva.....................24

1.5.1.2 Competência administrativa comum........................24

1.5.2 Competência legislativa......................................................25

1.5.2.1 Competência exclusiva e privativa...........................26

1.5.2.2 Competência concorrente e suplementar..................26

1.5.2.3 Competência supletiva (plena)................................28

1.6 As competências implícitas..............................................................29

Capítulo 2 - A competência ambiental na Constituição e sua repartição em matéria legislativa

2.1 O meio ambiente na Constituição Federal de 1988................................31

2.2 Princípios norteadores da competência ambiental.................................37

2.2.1 O princípio da predominância do interesse...............................37

2.2.2 O princípio da subsidiariedade e o direito comparado..............38

2.3 Repartição da competência legislativa ambiental..................................45

2.3.1 O papel da União na competência ambiental..........................45

2.3.2 O papel dos Estados na competência ambiental.....................48

Capítulo 3 - A competência dos Municípios na legislação ambiental

3.1 Evolução da autonomia municipal na Federação........................52 
3.2 A competência material do Município.

3.3 A competência legislativa do Município 60

3.3.1 O interesse local .61

3.3.2 A suplementação de lei federal .66

3.4 Os limites materiais da legislação ambiental dos Municípios....70

3.5 O controle de constitucionalidade das leis municipais e as espécies de inconstitucionalidades 77

\section{Capítulo 4 - Casos representativos da discussão}

4.1 A proibição da queima da palha da cana de açúcar....................83

4.2 A proibição do uso das sacolas plásticas.....................................95

4.3 A proibição da utilização do amianto crisotila..........................107

4.4 Lei da Cidade Limpa................................................................115

4.5 Restrição ao consumo do tabaco..............................................119

4.6 Taxa de Preservação Ambiental em cidade litorânea................123

4.7 A proibição da extração de minérios..........................................127

4.8 Legislação baseada no princípio da precaução..........................130

4.8.1Restrição aos organismos geneticamente modificados.132

4.8.2 Poluição eletromagnética.............................................137

Conclusão 149

Bibliografia. 154 


\section{INTRODUÇÃO}

Historicamente, os seres humanos puderam atender às suas necessidades com uma grande quantidade de recursos naturais. A natureza sempre foi vista como ilimitada à espécie humana, pois havia vasta disponibilidade dos bens ambientais à disposição do homem. Como o modo de vida não era significativamente predatório, era comum certo otimismo sobre a possibilidade de se explorar infinitamente os recursos ambientais. Sob tal visão, o filósofo Francis Bacon pregava, no início da ciência moderna, o domínio total da natureza pelo homem, numa relação de servo-senhor ${ }^{1}$.

Com o advento da revolução industrial, todavia, os meios de produção capitalista ampliaram-se exponencialmente, assim como as necessidades de consumo da população. Além disso, o índice demográfico crescia vertiginosamente, ao mesmo tempo em que se assentava a sociedade industrial e urbana ${ }^{2}$.

Tais fatores conjugados trouxeram graves problemas ambientais, muito dos quais foram aos poucos sendo percebidos pelos sinais de esgotamento dos recursos naturais. A limitação física dos bens do planeta, que jamais havia sido cogitada por outras sociedades, passou a ser uma das maiores preocupações do homem na transição do século XX para o XXI. Foi percebido que, se nada fosse feito, a própria sobrevivência da civilização tal qual se conhece estaria ameaçada.

Como muito bem observou Alaôr Caffé Alves, "o sistema, muitas vezes, não tem uma dimensão criteriosa e crítica, por ser calcado na perspectiva de uma lógica acumulativa do sistema capitalista, de reprodução acumulativa, sem levar em conta a totalidade do sistema vital e universal do homem.",

Somente com essa mudança de paradigma global é que foi necessário o surgimento do hoje chamado 'direito ambiental'. Ele nasceu do conjunto de princípios e regras jurídicas que passaram a disciplinar a preservação e a racional

\footnotetext{
${ }^{1}$ MORA, J. Ferrater. Dicionário de Filosofia. São Paulo: Loyola. 1994, p. 765.

${ }^{2}$ CORTEZ, Ana Tereza C.; ORTIGOZA, Silvia Aparecida G. (Org.). Da produção ao consumo - impactos socioambientais no espaço urbano. São Paulo: Editora UNESP. 2009, p. 92.

${ }^{3}$ ALVES, Alaôr Caffé. Meio ambiente e a questão metropolitana. In: Alaôr Caffé Alves; Arlindo Philippi Jr; Marcelo de Andrade Roméro; Gilda Collet Bruna. (Org.). Meio Ambiente, Direito e Cidadania. $1^{\mathrm{a}}$ ed. São Paulo: SIGNUS / NISAM-USP, v.1, 2002, p. 14.
} 
utilização dos recursos ambientais. Seu crescimento também se deu em função de casos de degradação ambiental de grandes proporções que passaram a ficar conhecidos, os quais influenciaram na formação de ordenamentos jurídicos específicos nas nações. ${ }^{4}$ Assim, tal ramo do Direito busca assegurar não só a manutenção dos recursos ambientais, mas principalmente a continuidade da sadia qualidade de vida humana, tanto às presentes como às futuras gerações.

Tal ideal somente poderá ser alcançado se forem implementados os ideais de desenvolvimento sustentável, que fora definido pelo 'Relatório da Comissão Mundial sobre Meio Ambiente e Desenvolvimento: Nosso Futuro Comum,5, conhecido por "Relatório Brundtland", como sendo o desenvolvimento que satisfaz as necessidades das presentes gerações sem comprometer as das sociedades do porvir.

Ocorre que o quadro de devastação ecológica que se vivencia nas últimas décadas é extremamente vasto: como o aquecimento global, as espécies ameaçadas de extinção, as diversas formas de poluição urbana (visual, sonora, dos solos, das águas, do ar), entre outros.

Diante disso, inúmeras são as formas possíveis de contenção da degradação ambiental e promoção do meio ambiente ecologicamente equilibrado. No plano internacional, têm sido elaborados inúmeros acordos, tratados, convenções, pactos, entre outros instrumentos político-jurídicos, que visam à melhoria da qualidade ambiental. No plano interno, também se podem verificar as mais diversas alternativas em prol do ambiente, seja pelos entes públicos, seja pela iniciativa privada e também pelo terceiro setor.

Dentre essas inúmeras tentativas de ações em prol do meio ambiente, a presente dissertação se limitará ao estudo das legislações municipais que visam a garantir maior proteção ao meio ambiente local e à saúde da população envolvida.

Antes de analisá-las especificamente, será demonstrado que há certo questionamento acerca da viabilidade jurídico-formal de referidas leis, sob o argumento de que a Constituição Federal de 1988 não outorgou competência legislativa ao Município para tratar do meio ambiente.

\footnotetext{
${ }^{4}$ SAMPAIO, Rômulo Silveira da Rocha. Direito ambiental - doutrina e casos práticos. Rio de Janeiro: Elsevier Editora. 2012, p. 39.

5 Annex to document A/42/417. Report of the World Comission on Environment and Development: Our Common Future. General Assembly, UN. 1987. Disponível em: http://www.un-documents.net/wced-ocf.htm
} 
Nesse contexto, a presente dissertação inicialmente trará breves considerações acerca do Federalismo adotado na última Carta Magna, para em seguida analisar como foi estabelecida a repartição da competência constitucional, notadamente sobre as disposições relacionadas ao meio ambiente.

Firmada essa base teórica, passar-se-á a verificar o papel da União e dos Estados na competência legislativa ambiental. A partir da delimitação das competências dos entes superiores, será possível depreender mais claramente a possibilidade dos Municípios editarem leis mais protetivas ao meio ambiente local.

Sob essa perspectiva, será feito um cotejo entre os princípios que norteiam a repartição de competências constitucionais, quais sejam, o princípio da predominância do interesse e o princípio da subsidiariedade. Ambos devem ser considerados em conjunto para se chegar a uma conclusão a respeito da possibilidade dos entes públicos atuarem com mais eficácia para solucionar as demandas ambientais da sociedade ${ }^{6}$.

Visando melhor sistematizar a questão, será feita uma análise constitucional da competência municipal, notadamente da possibilidade do ente local legislar suplementarmente para restringir atividades e práticas potencialmente causadoras de danos ambientais que não estejam proibidas pela União ou pelos Estados, com vistas ao atendimento do interesse local.

Para tanto, imperioso será o estudo do papel do Município como ente da Federação, status que só foi por ele obtido na última Constituição Federal. Desde então, os ideais de maior autonomia ao ente municipal têm crescido exponencialmente na doutrina, buscando-se romper com a tradição centralizadora dominante no País.

Todo esse fortalecimento do Município na Federação refletiu-se no alargamento de suas competências, de modo que a repartição constitucional conferiu-lhe a tarefa de legislar privativamente sobre os "assuntos de interesse local", assegurou-lhe a possibilidade de suplementação das leis estaduais e federais, bem como lhe impôs a competência comum de proteção do meio ambiente e do combate à poluição ${ }^{7}$.

Em que pesem as inúmeras dificuldades provenientes desta opção descentralizadora, parece este ser um bom caminho para se buscar um aumento da

${ }^{6}$ LEUZINGER, Márcia Dieguez; CUREAU, Sandra. Direito Ambiental. Rio de Janeiro: Elsevier Editora, 2008 , p. 43.

${ }^{7}$ CASTRO, José Nilo de. Direito Municipal Positivo. Belo Horizonte: Editora del Rey. 2006, p. 205. 
efetividade na proteção ambiental. Aguarda-se, assim, que os Municípios aproveitem esta expansão de suas competências para legislarem adequadamente aos desígnios do artigo $225^{8}$ da Constituição Federal, almejando sempre a busca do meio ambiente ecologicamente equilibrado para as presentes e futuras gerações.

E para poder exercer eficazmente tal mister, os Municípios terão, antes de mais nada, que enfrentar a resistência de parte dos membros do Poder Judiciário, os quais têm declarado a inconstitucionalidade de muitas das leis ambientais locais, sob pretexto de que faltaria competência aos Municípios para restringir atividades e produtos não proibidos pela legislação estadual e/ou federal.

Por outro lado, pode-se enxergar uma mudança dessa jurisprudência centralizadora, notadamente pela sensibilidade demonstrada por parte dos Ministros do Supremo Tribunal Federal, assim como por alguns votos dos Desembargadores do Tribunal de Justiça do Estado de São Paulo. Como será demonstrado, hoje já existem importantes precedentes a favor da competência legislativa dos entes municipais.

Assim, o presente trabalho buscará analisar a possibilidade de o Município editar leis ambientais mais protetivas e, para a melhor verificação desta competência constitucional, serão utilizados inúmeros casos concretos exemplificativos, os quais demonstram que já há grande debate a respeito do tema. Como exemplo, podem ser citadas algumas leis paradigmáticas, como a recente proibição da utilização de sacolas plásticas no comércio da cidade de São Paulo, a tentativa de vedação da queima da palha da cana-de-açúcar em inúmeras cidades do interior paulista, a Lei da Cidade Limpa, entre outros importantes precedentes.

Todos os casos concretos serão analisados individualmente, de modo que será feita uma análise acurada dos argumentos utilizados pelos Desembargadores ou Ministros para fundamentar as decisões de constitucionalidade ou inconstitucionalidade das leis municipais.

\footnotetext{
8 "Todos têm direito ao meio ambiente ecologicamente equilibrado, bem de uso comum do povo e essencial à sadia qualidade de vida, impondo-se ao Poder Público e à coletividade o dever de defendê-lo e preservá-lo para as presentes e futuras gerações".
} 


\section{Capítulo 1 - A ADOÇÃO DO MODELO FEDERATIVO E A REPARTIÇÃO DE COMPETÊNCIA NA CONSTITUIÇÃO FEDERAL DE 1988}

\subsection{Da organização do Estado}

De acordo com o caput do artigo $1^{\mathrm{o}}$ da Constituição Federal, a República Federativa do Brasil, constituída em Estado Democrático de Direito, é formada pela união indissolúvel dos Estados e Municípios.

Primeiramente, cumpre lembrar que a noção de Estado está ligada à ideia de sociedade politicamente organizada dentro de determinado espaço territorial e que tem por fim o bem estar de todos ${ }^{9}$. Este Estado pode ser classificado de diferentes maneiras, principalmente quanto à forma de governo, sistema de governo, regime de governo e forma de Estado.

Forma de governo pode ser entendida não só como o modo de instituição do poder na sociedade, mas também como a relação entre governantes e governados. Atualmente, duas são as formas comumente adotadas pelos Estados: a Monarquia e a República.

A Monarquia, sinteticamente, é a forma de governo pelo qual o monarca adquire o poder de forma hereditária, passando a exercer um mandato perpétuo e vitalício. Além disso, como sua escolha comumente é justificada por razão divina, o exercício de seu poder é realizado com base na irresponsabilidade, isto é, não haveria o dever de prestar contas à sociedade ou a qualquer órgão político de suas decisões. Conforme recorda Dalmo de Abreu Dallari ${ }^{10}$, a Monarquia foi adotada "por quase todos os Estados do mundo" durante muitos séculos, mas acabou sendo gradativamente enfraquecida e abandonada pela maioria dos países.

\footnotetext{
${ }^{9}$ DALLARI, Dalmo de Abreu. Elementos de teoria geral do Estado. 24.ed Sã Paulo: Saraiva, 2003, p. 118.

${ }^{10}$ DALLARI, Dalmo de Abreu. Op. Cit. 2003 p. 226.
} 
De forma diametralmente oposta, na República a aquisição do poder está vinculada a realizações de eleições, e, por isso, há prazo determinado para os mandatos dos governantes. No Brasil, inclusive, o voto direto, secreto, universal e periódico é cláusula pétrea, nos termos do artigo $60, \S 4^{\circ}$, inciso II, da Constituição Federal.

Outra dentre as principais características desta forma de governo é a necessidade de prestação de contas pelo governante, o qual é responsável pela gestão da coisa pública e está sujeito ao sistema de controle de sua atuação, inclusive sendo permitido o impeachment nos casos de crimes de responsabilidade (infrações políticoadministrativas). Atualmente, referida previsão está expressa no artigo 85 da Constituição Federal de 1988.

Etimologicamente, República deriva da justaposição de "res" “publica”, referindo-se a coisa pública, coisa do povo, para o povo, se relacionando ao interesse público primário, isto é, aqueles interesses do Estado que são os interesses da sociedade enquanto coletividade. Apesar da República não estar expressamente no rol das cláusulas pétreas, pode-se afirmar que estaria implícita no texto constitucional, inclusive porque foi tratada como princípio constitucional sensível, nos termos do artigo 34, inciso VII, aliena "a”, da Constituição.

Como é sabido, o modelo republicano é o adotado no Brasil desde o fim da Monarquia (15 de novembro de 1889), estando presente em todas as constituições brasileiras desde 1891, inclusive sendo corroborada na Constituição Federal de 1988 e posteriormente ratificada no plebiscito realizado no ano de 1993, no qual os cidadãos deveriam escolher entre a forma de governo monárquica ou republicana.

Já no que concerne ao sistema de governo, este pode ser definido como o estudo a respeito da relação entre os Poderes Executivo e Legislativo, de modo que pode haver maior interdependência ou maior liberdade entre ambos. Destacam-se atualmente dois sistemas: o parlamentarismo e o presidencialismo.

O primeiro é marcado pela maior dependência de referidos poderes, haja vista que os mandatos do primeiro ministro e dos parlamentares possuem prazo incerto, dependendo das moções ou crises de confiança para manutenção ou alteração do governo. Traço marcante do parlamentarismo é o fato de haver duas pessoas diferentes exercendo a chefia de Estado (monarca ou presidente) e a chefia de Governo (primeiro ministro). Enquanto o Chefe de Estado precipuamente representa o país, o Chefe de 
Governo exerce o poder executivo, possuindo relevante responsabilidade política. Diante desta dicotomia de chefias, e considerando que em alguns casos o Chefe de Estado também exerce algumas funções políticas, passou-se a denominar este Parlamentarismo de um sistema de governo dual (ou dualista), o qual é adotado normalmente nas monarquias constitucionais.

De modo diverso, no Presidencialismo, apesar da harmonia, há clara independência entre os poderes Executivo e Legislativo, de modo que em ambos os mandatos possuem prazos determinados. No mais, nesse sistema inexiste, por exemplo, possibilidade de dissolução do Legislativo pelo chefe de governo, pois há maior rigidez na relação entre os Poderes, em consonância com o princípio da separação dos poderes. Além disso, a chefia deste sistema de governo é unipessoal e escolhida diretamente pelo povo, de modo que o presidente acumula as funções de chefe de Estado e chefe de Governo, tendo exclusividade na execução de seu plano de governo. Finalmente, importante recordar que este sistema é típico dos países republicanos.

No que tange aos regimes de governo, pode-se distinguir dois regimes principais, baseados na participação do povo na tomada de decisões do Estado, seja de forma direta, seja por meio dos representantes que elegem.

$\mathrm{Na}$ autocracia, o povo não participa das políticas governamentais, de forma que o governante impõe sua vontade unilateralmente. Assim, pode-se dizer que há um governo estruturado de cima para baixo, pois tanto a elaboração das normas como a execução das políticas públicas serão realizadas pelo governante independentemente da vontade do povo.

De outro lado, no regime democrático há plena participação do povo nos rumos do Estado. Isso porque, sendo o titular do poder constituinte originário, o povo tem o poder de estabelecer a Constituição e todas as formas pelos quais haverá manifestação do Poder Estatal. Para a efetivação deste governo do povo, deve-se buscar atender a vontade da maioria, mas sempre com respeito aos direitos das minorias.

A complexidade da sociedade atual faz com que haja a necessidade prática da prevalência da democracia indireta (ou representativa), pois não se mostra viável que o governo seja exercido precipuamente com consultas populares, sendo certo que o povo elege representantes periodicamente para exercer as funções governamentais. Não obstante, é comum haver alguns institutos da participação direta do povo nas funções 
governamentais, a exemplo do plebiscito, do referendo e da iniciativa popular para projetos de lei. Em razão desta combinação, chega-se a uma democracia semidireta.

Já o conceito de forma de Estado relaciona-se ao modo de exercício do poder político em função do território do Estado, podendo haver ou não repartição com poderes autônomos. No Brasil, desde a proclamação da República passou a ser adotado o modelo federativo, de forma que o poder foi repartido entre os entes federados, que possuem autonomia. Assim, referida opção se deu em detrimento do Estado Unitário, no qual há extrema centralização (o qual, inclusive, foi vivenciado durante a maior parte da história do País - todo o período colonial e imperial).

O federalismo não só foi a forma de Estado adotado por todas as Constituições brasileiras desde 1891, como atualmente figura como cláusula pétrea da Constituição Federal de 1988, de acordo com o artigo 60, $\S 4^{\circ}$, inciso I. Assim, faz parte do núcleo duro da constituição, sendo imutável e não podendo nem mesmo sofrer proposta de emenda tendente a aboli-la.

Etimologicamente, Federação decorre de foedus, foederis, que significa aliança, união. Para restar caracterizada, pode-se apontar alguns elementos essenciais, como a descentralização política, a autonomia, a possibilidade de autoconstituição (em regra), a inexistência do direito de secessão, bem como a repartição de competência s e de receitas.

Assim, uma Federação deve buscar preservar a unidade nacional sem comprometimento das autonomias regionais. Enquanto as unidades federadas mantêm autonomia política, a soberania é transferida para o Estado Federal, de forma a coexistir diferentes esferas políticas dentro do mesmo Estado.

O fato de o Brasil constituir-se numa Federação é deveras relevante para se entender as divisões das competências entre os entes federados. Uma constituição federativa deve buscar equalizar certa distribuição de competência que garanta autonomia a todos os entes. Deve-se manter a existência de um poder central, mas sem que isso aniquile os poderes locais de exercerem suas funções estatais.

Na Constituição Federal de 1988, ver-se-á que houve a repartição das competências da Federação entre os seus três níveis de entes federados: União, Estados (também o Distrito Federal) e Municípios. O fundamento desta partilha de poder seria o propósito de facilitar o adequado exercício das atribuições da República Federativa do 
Brasil para com os seus cidadãos. Assim, a repartição de competência é a espinha dorsal do federalismo, garantindo ao mesmo tempo a autonomia dos entes federativos e o equilíbrio da Federação.

Na divisão de competências entre os entes federados, conforme será mais bem desenvolvido, adota-se como regra o critério da predominância do interesse, segundo o qual a União teria competência sobre as matérias de interesse nacional, os Estados sobre as de interesse regional e os Municípios sobre os assuntos de interesse local. Referida divisão, apesar de transparecer uma ideia precisa e até demasiadamente simples, na verdade faz parte de um complexo sistema de distribuição de competências, o qual exige esforço do operador do direito para se alcançar a busca de equilíbrio entre os entes.

Conforme muito bem pontua José Afonso da Silva, pode-se perceber que "são notórias as dificuldades quanto a saber que matérias devem ser entregues à competência da União, quais as que competirão aos Estados e quais as que se indicarão aos Municípios". ${ }^{11}$ Isso porque está cada vez mais difícil estabelecer uma grande diferenciação entre os assuntos que seriam de interesse nacional, regional ou local.

Apesar das dificuldades, a constante busca do equilíbrio na divisão de competências deve sempre almejar assegurar a unidade na diversidade. Assim, será visto que a União poderá dispor sobre os princípios, os fundamentos, as normas-diretrizes e uniformizadoras, ao mesmo tempo em que os demais entes complementariam para melhorar adaptar as leis às suas condições locais, sem perder a harmonia do sistema.

A solução teórica, todavia, não tem sido aplicada na prática, pois a doutrina afirma que em nossa Federação a União exerce papel predominante na produção legislativa, reduzindo os Estados e os Municípios, na prática, "a papéis praticamente insignificantes" 12 .

Buscando reverter este quadro, a Constituição Federal de 1988, de maneira inovadora, buscou imprimir força ao pacto federativo, invertendo esta tendência centralizadora verificada desde a proclamação da República Federativa. E para assegurar a autonomia das entidades federativas, trouxe mudanças no modelo de repartição de competências até então vigente. Referido tratamento constitucional merece ser

\footnotetext{
${ }^{11}$ SILVA, José Afonso da. Curso de Direito Constitucional Positivo. São Paulo: Malheiros Editores. 2008. $30^{a}$ edição. p. 477.

12 ANTUNES, Paulo de Bessa. Federalismo e Competências Ambientais no Brasil. Rio de Janeiro: Editora Lumen Juris, 2007. p. 160/162.
} 
devidamente estudado para se poder chegar a uma conclusão acerca da possibilidade do ente municipal criar leis mais protetivas ao meio ambiente.

\subsection{Breve histórico do federalismo}

A forma federativa de Estado teve sua origem nos Estados Unidos, no ano de sua primeira Constituição - 1787. O modelo de estado federativo foi a solução encontrada para se manter a união dos treze Estados independentes norte-americanos ${ }^{13}$.

Pela Federação estabelecida, cada Estado cederia parcela de sua soberania para um órgão central, o qual ficaria responsável pela centralização e unificação dos Estados Unidos da América. Assim, houve um movimento centrípeto (de fora para dentro), no qual os Estados até então independentes se aglutinaram, criando um poder central único (federalismo por agregação).

Diante deste nascedouro, até hoje os Estados Unidos tem um governo central demasiadamente limitado, em razão dos fortes poderes e autonomia de que os governos regionais dispõem. Contribui para isso haver neste país um federalismo simétrico, pois ao mesmo tempo em que há equilíbrio na repartição de competências, também há homogeneidade cultural, incluindo língua comum e grau de desenvolvimento semelhante. Essa forma norte-americana, que originou o Estado federal, acabou por receber adaptações nos países que vieram a adotar a forma federativa de Estado.

No Brasil, diferentemente do ocorrido nos Estados Unidos, a formação federativa proveio de um movimento centrífugo (de dentro pra fora). Se antes havia um Estado unitário centralizado, passou-se a constituir um Estado descentralizado (federalismo por desagregação).

Essa diferenciação histórica da implementação do federalismo nos Estados Unidos e no Brasil até hoje influencia o grau de autonomia dos entes menores em comparação com o poder central. Acostumados com muita autonomia, os Estados norteamericanos mantiveram-na em grande medida mesmo após a constituição do Estado federado, e, por isso, ainda detêm muito mais autonomia que os Estados-membros brasileiros.

\footnotetext{
${ }^{13}$ DALLARI, Dalmo de Abreu. Op. cit. 2003. p. 255.
} 
Essa divisão vertical de poder em muito serviu para que não houvesse abusos de um ente federado em relação ao outro. Isso porque, a liberdade política só pode ser alcançada com um sistema de freios e contrapesos, de modo que um poder limita os demais. O Brasil adotou a clássica tripartição de poderes, divididos em Poder Executivo, Legislativo e Judiciário ${ }^{14}$. Mas ao lado dessa divisão horizontal, também se mostra relevante a distribuição de poder/competência verticalmente entre os entes federados.

O regime federativo pressupõe que os entes vão dividir as tarefas essenciais do Estado-Nação, cooperando uns com os outros para alcançar o bem comum.

\subsection{A Federação brasileira}

A Federação brasileira está assentada na ideia de repartição de competência com vistas a garantir autonomia entre os entes federativos e, ao mesmo tempo, alcançar o equilíbrio da Federação.

$\mathrm{O}$ artigo $1^{\circ}$, caput, da Constituição Federal, prevê a indissolubilidade dos entes federados, de modo a não haver hierarquia entre a União e os demais entes, haja vista que há uma clara fixação da competência de uns e outros.

Referido artigo deve ser lido conjuntamente com o caput do artigo 18, que também traz a peculiaridade brasileira da inclusão do Município como ente da Federação. Pode-se dizer, assim, que a Carta Magna de 1988 buscou imprimir maior força ao pacto federativo, indo de encontro à centralização vigente até então.

Pela leitura dos dispositivos constitucionais supramencionados percebe-se que foi criada uma Federação em três níveis, diferentemente do que há em qualquer outro país do mundo. Édis Milaré assevera que "embora único, esse modelo espelha uma tendência mundial, que é a de uma crescente afirmação das autonomias locais" " Essa inclusão do Município faz o federalismo brasileiro ser denominado tricotômico, trino, tríplice ou tripartido.

\footnotetext{
${ }^{14}$ RICHTER, Melvin. The Political Theory of Montesquieu. Estados Unidos: Cambridge University Press, 1977, p. 92.

${ }^{15}$ MILARÈ, Edis. Direito do ambiente: a gestão ambiental em foco: doutrina, jurisprudência, glossário. São Paulo: Revista dos Tribunais. 2009, p. 189.
} 
No Brasil, como a tradição do Estado unitário sempre foi muito presente, seria preciso transferir poderes aos entes menores de forma gradual, para que aos poucos pudessem consolidar essa visão de Federação descentralizadora. Só assim possibilitar-se-ia uma descentralização política adequada, distribuindo-se o que até então estava inteiramente sob a competência do poder central (União), paulatinamente, aos poderes regionais e locais.

Outra questão importante sobre o federalismo brasileiro é sua classificação como 'federalismo cooperativo'. Como o próprio nome sugere, significa que as atribuições entre os entes federados se darão de forma cooperativa, conjunta, em um exercício coordenado de competências, de modo comum ou concorrente ${ }^{16}$.

Essa classificação se contrapõe ao clássico modelo de federalismo dual, no qual há rígida separação de competência entre os entes, especialmente entre a entidade central (União) e os demais entes federados. Assim, percebe-se que a Constituição Federal de 1988 estabeleceu um federalismo cooperativo no Brasil, com vista a um maior inter-relacionamento entre os diferentes níveis de poderes políticos.

Conforme será demonstrado, neste federalismo de integração, a distribuição de competências entre a União, Estados e Municípios se faz como um compromisso de união de esforços para realizar o bem-estar da coletividade da melhor maneira possível.

Assim, a República Federativa do Brasil é fundada no equilíbrio de suas competências constitucionais entre os entes federados, daí se falar que foi adotado um federalismo de equilíbrio.

Outra possível abordagem para o federalismo brasileiro se refere ao que foi denominado 'federalismo de $2^{\circ}$ grau'. A justificativa para tal denominação se dá pela tríplice estrutura do Estado Brasileiro, sendo a União a ordem central, os Estados as ordens regionais e os Municípios as ordens locais. Assim, os entes municipais deveriam não só observar a Constituição Federal, mas também a Constituição do respectivo Estado, e, por isso, haveria um federalismo de $2^{\circ} \operatorname{grau}^{17}$.

\footnotetext{
${ }^{16}$ CAMARGO, A. Federalismo cooperativo e o princípio da subsidiariedade: notas sobre a experiência recente do Brasil e da Alemanha. In: HOFMEISTER, W., CARNEIRO, J. M. B. (Orgs.). Federalismo na Alemanha e no Brasil, Série Debates, n.22, v.1. São Paulo: Fundação Konrad Adenauer, 2001, p. 83.

${ }^{17}$ FERREIRA FILHO, Manoel Gonçalves. Curso de Direito Constitucional. São Paulo: Saraiva, 1992, p. 48.
} 
Assim, pode-se sintetizar toda esta complexidade do federalismo brasileiro na busca de um equilíbrio entre os poderes nacionais e regionais, assegurando a possibilidade da União, Estados e Município exercerem suas competências na forma do que foi estabelecido pela Constituição Federal

\subsection{0 conceito de competência no direito pátrio}

Para se poder tratar apropriadamente do tema 'competência', imprescindível se faz a busca de uma definição a respeito deste termo. Diante da dificuldade inerente em precisar um tema tão complexo, será necessária a comparação das abordagens do conceito por alguns dos mais renomados autores jurídicos que trataram do tema.

Valendo-se primeiramente das lições de José Afonso da Silva, temse que "Competência é a faculdade juridicamente atribuída a uma entidade ou a um órgão ou agente do Poder Público para emitir decisões. Competências são as diversas modalidades de poder de que se servem os órgãos ou entidades estatais para realizar suas funções."18

No mesmo sentido é a definição de Canotilho, em que competência seria "o poder de acção e de actuação atribuído aos vários órgãos e agentes constitucionais com o fim de prosseguirem as tarefas de que são constitucionalmente ou legalmente incumbidos" $"$.

Já na concepção de Tércio Sampaio Ferraz Junior, “Trata-se de uma forma de poder jurídico, isto é, de exercício impositivo de comportamento e relação de autoridade regulado por normas". ${ }^{20}$

O que se pode perceber da leitura conjunta das três definições supracitadas, é que o conceito de competência obrigatoriamente trata da questão do poder.

\footnotetext{
${ }^{18}$ SILVA, José Afonso da. Op. cit. p. 479.

${ }^{19}$ CANOTILlHO, J. J. Gomes. Direito Constitucional e Teoria da Constituição. $7^{\mathrm{a}}$ ed. Portugal - Coimbra: Ed. Almedina, 2003, p.543.

${ }^{20}$ FERRAZ Jr, Tércio Sampaio. Normas gerais e competência concorrente - uma exegese do art. 24 da Constituição Federal. São Paulo: Malheiros, Revista trimestral de direito público, no 7. 1994, p. 17.
} 
O Estado concentra o poder político que a sociedade lhe atribui, e, como não pode exercê-lo somente por um único órgão, acaba por distribuir tal poder aos seus entes, os quais o recebem-no na forma de competência para exercer a vontade do Estado.

Por isso, não há como precisar o que seria competência sem relacioná-la com a quantidade ou até qualidade de poder distribuído aos entes do Estado para a consecução de suas finalidades.

Isto posto, passa-se a analisar especificamente como foi realizada essa distribuição das competências na Constituição Federal, tanto no âmbito administrativo quanto no legislativo.

\subsection{Classificação das competências}

A Constituição Federal de 1988 estruturou-se num complexo sistema de repartição de competências, notadamente criando dois grandes blocos: a competência administrativa e a legislativa.

Com relação à primeira, houve sua divisão em competência administrativa comum e exclusiva. Já quanto à segunda, houve uma subdivisão ainda maior, abarcando a competência legislativa exclusiva, a privativa, a concorrente, a supletiva e a suplementar. Diante dessa secção constitucional das competências, se mostra salutar explicá-las em subtópicos separados.

\subsubsection{Competência Administrativa}

A competência administrativa, também denominada de material ou não legislativa, refere-se ao poder-dever de gerir a coisa pública, isto é, de atuar de modo concreto para a realização dos fins estatais.

Referida competência regulamenta o campo de atuação políticoadministrativa de um ente na prestação de serviços públicos. De acordo com a divisão feita 
na Carta Magna, tal exercício pode ter sido incumbido de modo exclusivo a só uma esfera estatal, bem como pode estar afeta de maneira comum a todos os entes.

\subsubsection{Competência administrativa exclusiva}

As competências materiais exclusivas são marcadas principalmente pelo fato de serem indelegáveis, de modo que nessas áreas somente um ente estatal terá o poder de agir.

Tais competências são a regra do ordenamento, estando arroladas as competências materiais exclusivas da União no artigo 21 da Constituição, as competências dos Municípios no artigo 30, incisos III a IX, e as dos Estados serão aquelas que não tiverem expressamente conferidas aos dois primeiros entes (artigo $25, \S 1^{\circ}$ ). Por isso, diz-se que a competência material exclusiva dos Estados são remanescentes ou residuais.

\subsubsection{Competência administrativa comum}

As competências materiais comuns são aquelas em que todos os entes federativos podem atuar simultaneamente, daí também se denominar competência paralela ou cumulativa. Todos têm interesse na consecução das matérias arroladas no artigo 23 da Constituição, haja vista se tratarem precipuamente de direitos difusos, isto é, aqueles que interessam a toda sociedade.

Para fazer valer tal competência constitucional, imprescindível se faz a colaboração administrativa dos entes, para não haver problemas na ação simultânea. A solução das matérias aqui tratadas só será alcançada com a cooperação entre os entes atuantes. Sabendo disso, a Constituição Federal foi expressa em deixar estabelecido que "leis complementares" estabelecerão normas de cooperação, que se farão sempre com vistas à busca do equilíbrio entre a atuação dos entes públicos. 
Conforme recorda Paulo de Bessa Antunes, esta colaboração deve ser feita racionalmente, para que os "serviços sejam prestados da forma mais eficiente possível e com a maior economia de recursos públicos". ${ }^{21}$

Como não há prevalência de um ente sobre o outro em tais matérias, somente com o estabelecimento de instrumentos jurídicos de cooperação - como os convênios - poderão ser otimizados os esforços na busca do bem comum.

Na seara ambiental especificamente, buscando evitar a dispersão de recursos causados pelos conflitos entre os entes, foi promulgada recentemente a Lei Complementar $n^{\circ}$ 140/11. Referida lei regulou a coordenação da atuação das ações em prol do meio ambiente, possibilitando o estabelecimento de convênios, a descentralização de encargos, entre outros instrumentos.

Somente após um tempo maior poderão ser analisados os impactos reais da aplicação desses instrumentos na melhoria da qualidade ambiental. Apesar disso, a alteração legislativa por si só já mostra a preocupação do Estado na cooperação de seus entes para a busca da melhor salvaguarda do meio ambiente.

Por fim, como o tratamento do meio ambiente foi incluído na competência material comum, muitos advogam que este dever de cuidado traria tacitamente uma correlata competência legislativa sobre a matéria. Diante da relevância deste tema para a verificação da possibilidade do Município editar leis ambientais, tais “competências implícitas” serão analisadas em tópico separado.

\subsubsection{Competência legislativa}

Como o próprio nome sugere, as competências legislativas são aquelas relacionadas às atribuições dos entes políticos para que estabeleçam leis, isto é, a aptidão para legislar.

Esta atribuição constitucional dos entes federados em poder editar suas próprias leis é de suma importância para a Federação. Nesse sentido é a lição de Fernanda Dias Menezes de Almeida: “A partilha do poder de legislar é sempre o fulcro da

\footnotetext{
${ }^{21}$ ANTUNES, Paulo de Bessa. Op. cit. p. 184.
} 
repartição de competências, já que a lei - pensando-se em termos de Estado de direito - é que dá a dimensão do exercício dos demais poderes". ${ }^{22}$

De acordo com a divisão feita na Constituição Federal, serão vistas sucintamente as diferentes competências legislativas que foram estabelecidas.

\subsubsection{Competência exclusiva e privativa}

As competências exclusivas e as privativas são aquelas que autorizam a União a impor um tratamento uniforme em todo o território nacional. Enquanto as primeiras estão previstas no artigo $25, \S \S 1^{\circ}$ e $2^{\circ}$ da Constituição Federal e são indelegáveis, as segundas estão arroladas no artigo 22 e tratam de matérias que podem vir a ser delegadas.

Tal previsão está expressa no parágrafo único do mesmo artigo 22, o qual estabelece que a União poderá, por meio de lei complementar, autorizar os Estados a legislar sobre as matérias constantes desse artigo. Não havendo delegação nesses casos, fica excluída a possibilidade de os Estados e Municípios legislarem sobre tais matérias, pois a regra é de que tais entes só podem atuar obedecendo os limites e condições da lei federal.

\subsubsection{Competência concorrente e suplementar}

A competência concorrente foi tratada no artigo 24 da Constituição Federal e se refere àquelas matérias em que será necessária uma verdadeira "divisão de tarefas" a ser compartilhadas entre União, Estados e Distrito Federal. Na definição de José Afonso da Silva, esta competência concorrente seria a "possibilidade de disposição sobre o mesmo assunto ou matéria por mais de uma entidade federativa",23

O campo de atuação de cada ente está delimitado na própria Carta Magna, ao dispor que a União tem primazia para a fixação de normas gerais, enquanto os

\footnotetext{
${ }^{22}$ ALMEIDA, Fernanda Dias Menezes de. Competências na Constituição de 1998. $5^{\text {a }}$ edição. São Paulo: Atlas, 2010. p. 60.

${ }^{23}$ SILVA, José Afonso da. Op. cit. p. 481.
} 
Estados e Distrito Federal poderão suplementá-las editando leis mais específicas sobre as matérias.

Valendo-nos ainda das lições de José Afonso da Silva, pode-se afirmar que estas suplementações seriam "o poder de formular normas que desdobrem o conteúdo dos princípios ou normas gerais ou que supram a ausência ou omissão destas"24.

Assim, competência suplementar estaria ligada à possibilidade de edição de leis que pormenorizem as normas gerais da União, suplementando, desdobrando ou detalhando, de acordo com suas peculiaridades locais, os princípios já baixados pela norma federal.

Embora os Municípios tenham sido aparentemente excluídos da titularidade desta competência, por não constarem no artigo 24 da Constituição, verifica-se que sua competência suplementar está expressa no artigo 30, inciso II, de modo que também cabe ao ente municipal a edição de leis suplementando as normas federais e estaduais.

Muitos assuntos importantes foram incluídos sob o manto da competência concorrente. Para este trabalho, destacam-se a proteção do meio ambiente, o controle da poluição, a defesa dos solos e dos recursos naturais, a conservação da natureza, a responsabilidade por danos ao meio ambiente, o direito urbanístico, entre outros.

Tal previsão se mostra salutar para o tratamento de tais questões. Fernanda Dias Menezes de Almeida observou tal realidade com propriedade: "Parece-nos, efetivamente, que a utilização das competências concorrentes, como idealizada, atende aos desígnios de se chegar a uma maior descentralização, sem prejuízo da direção uniforme que se deva imprimir a certas matérias". 25

Como é sabido, apesar de haver certo consenso de que a União deveria uniformizar tais matérias, limitando-se a uma legislação abrangente, sem pormenores ou peculiaridades, ainda há divergência acerca dos limites da descentralização realizada pela suplementação de tais leis pelos Estados e Municípios.

Poder-se-ia argumentar tanto que tais entes deveriam somente preencher as lacunas deixadas pela normatização federal, sem jamais afrontá-la, como também que poderiam atender suas peculiaridades regionais/locais plenamente, inclusive

${ }^{24}$ SILVA, José Afonso da. Op. cit., p. 481.

${ }^{25}$ ALMEIDA, Fernanda Dias Menezes de. Op. cit. 61. 
confrontando as normas gerais. O estudo da argumentação completa de referido embate se mostra imprescindível para a análise da possibilidade dos Municípios legislarem mais restritivamente a respeito do meio ambiente. Diante de tal importância, esta discussão será desenvolvida nos capítulos subseqüentes, notadamente quando do estudo sobre a repartição da competência legislativa ambiental entre os entes da Federação.

\subsubsection{Competência supletiva (plena)}

Como visto acima, na competência concorrente é facultado aos entes menores suplementarem a legislação da União. Todavia, diante da possibilidade de inércia legislativa deste ente, surge explicitamente aos Estados a competência supletiva ou plena, nos termos do artigo $24, \S 3^{\circ}$ da Constituição Federal.

Isso significa que, não havendo norma geral da União sobre determinado assunto de competência concorrente, a competência suplementar do Estado passa também a ser supletiva, ou seja, será possível a edição de normas gerais por tal ente.

Ao mesmo tempo, justifica-se a competência plena dos Estados nos casos da existência de lei federal omissa sobre determinado assunto. Por isso, fala-se que a competência supletiva serve tanto para suprir a ausência como também a omissão das normas federais.

Esta possibilidade de legislação plena do ente Estadual foi uma das grandes novidades da Constituição Federal de 1988, haja vista que não se aventava tal possibilidade nas constituições anteriores.

Em que pese a Constituição não trate especificamente do Município neste artigo, pode-se argumentar que este ente também teria recebido tal competência na hipótese de não haver lei geral nem por parte da União, nem pelo Estado-membro correspondente. Essa interpretação decorreria da competência suplementar do Município constante no inciso II do artigo 30 da Constituição Federal.

Apesar de todo o ânimo do "status nascendi" de referida competência, não menos importante seria lembrar as limitações que ela sofre. Nas palavras de Paulo Affonso Leme Machado, haveria tanto uma limitação qualitativa como outra temporal. A primeira se referiria à impossibilidade da norma exorbitar o interesse do 
próprio ente que a está editando, não podendo se estender a norma regional/local para outras localidades. Já a limitação temporal se refere ao fato de que, em havendo a edição superveniente de norma geral da União, esta lei prevalecerá. ${ }^{26}$

Assim, conforme resta expresso no $\S 4^{\circ}$ do artigo 24 da Constituição Federal, "A superveniência de lei federal sobre normas gerais suspende a eficácia da lei estadual, no que lhe for contrário."

Com relação a esta última previsão constitucional, por fim, é importante atentar para o significado de 'suspender a eficácia', que não se confunde com revogação. Por isso, ao invés da lei anterior ser extirpada do ordenamento, ela ficará somente suspensa, o que significa que poderá eventualmente voltar a ter vigência se a lei nova da União for revogada ou declarada inconstitucional, por exemplo.

\subsection{Competências implícitas}

As competências implícitas, também chamadas de resultantes, inerentes ou decorrentes, são aquelas que não estão expressas no texto constitucional para um determinado ente.

São competências implícitas porque se referem aos atos que legitimamente se esperam de um ente para que ele cumpra de modo eficaz as competências materiais que lhe foram incumbidas.

Por isso, diz-se que a necessidade de implementação das competências administrativas traz consigo uma correlata competência legislativa referente a tais matérias. Assim, estariam os entes autorizados a legislar para poder agir adequadamente.

Nesse sentido, inclusive, é a 'teoria dos poderes implícitos', a qual, simplificadamente, preceitua que se a Constituição Federal atribui uma determinada finalidade a um ente federado, implicitamente estaria também lhe provendo de todos os meios necessários para a consecução deste mister.

Segundo Hely Lopes Meireles:

\footnotetext{
${ }^{26}$ MACHADO, Paulo Affonso Leme. Direito ambiental brasileiro. São Paulo: Malheiros Editora. 2009. p. 115 .
} 
"Poderes implícitos são os que resultam como conseqüência lógica e necessária de um poder explícito, ou dos princípios adotados pela Constituição. (...) A teoria dos poderes implícitos está constitucionalmente consagrada no nosso regime, como norma interpretativa de observância obrigatória na partilha da competência entre a União, os Estados-membros e os Municípios."27

Por isso, pode-se afirmar que a competência material pressupõe uma correlata competência legislativa, haja vista que somente com a edição de leis poderá o ente atuar eficazmente para cumprir o encargo atribuído pela Constituição.

Tratando especificamente da questão ambiental, tanto o artigo 23 da Constituição assegurou competência administrativa comum a todos os entes da federação, como o artigo 225 impôs o dever a todo o Poder Público de defender e preservar o meio ambiente.

Sob o respaldo desses argumentos, entende-se, portanto, que a Constituição Federal, por ter determinado uma obrigação comum de proteção do meio ambiente à União, aos Estados e também aos Municípios (competência material), acabou por assegurar a correlata competência legislativa a todos esses entes.

${ }^{27}$ MEIRELLES, Hely Lopes. Direito Municipal brasileiro. $15^{\mathrm{a}}$ edição, atualizada por Márcio Schneider Reis e Edgard Neves da Silva. São Paulo: Malheiros. 2006, p. 131/32 


\section{Capítulo 2 - A COMPETÊNCIA AMBIENTAL NA CONSTITUIÇÃO E SUA REPARTIÇÃO EM MATÉRIA LEGISLATIVA}

\subsection{O meio ambiente na Constituição Federal de 1988}

A Carta Magna atualmente vigente inovou em parte no tratamento da competência ambiental, principalmente no que concerne às competências legislativas.

A Constituição de 1967, por exemplo, não chegava a atribuir competência ao Estado-membro para legislar a respeito dos bens ambientais, incumbindo tal tarefa exclusivamente à União. Nesse sentido se alinhou a Política Nacional do Meio Ambiente (Lei n. 6.938/81), que mantinha essa atribuição única da União para dispor acerca de tais bens ambientais.

Já a Constituição Federal de 1988 mudou a sistemática até então existente, conferindo mais poderes aos entes inferiores. Apesar disso, como pondera Paulo de Bessa Antunes quanto às competências legislativas, "a repartição de competências ambientais, tal como posta na Constituição de 1988, é extremamente confusa e, seguramente, centralizadora." 28

A qualificação como confusa se justifica porque o federalismo brasileiro é bastante complexo, especialmente no tratamento das questões ambientais, nas quais a Constituição estabelece diferentes entes federados para o exercício da competência político-administrativa comum e para as competências legislativas concorrentes.

A característica de ser centralizadora é explicada pelo fato de ainda existir monopólio da União em determinados temas (por exemplo: águas, energia, recursos minerais etc). No entanto, apesar de haver certa concentração de competências na União, inegável que a privatividade até então existente foi certamente amenizada, pois muitas das mais importantes questões ambientais foram descentralizadas aos entes inferiores.

\footnotetext{
${ }^{28}$ ANTUNES, Paulo de Bessa. Op. cit. p. 104.
} 
$\mathrm{Na}$ divisão da competência material ou administrativa (artigo 23 da Constituição Federal), por exemplo, determinou-se a tutela comum de todos os entes públicos para "proteger o meio ambiente e combater a poluição em qualquer de suas formas", bem como para "preservar as florestas, a fauna e a flora".

Assim, considerando que a proteção do meio ambiente foi incluída no rol das competências comuns, tanto a União, os Estados, o Distrito Federal como os Municípios são igualmente competentes para a implementação das diretrizes e políticas de resguardo do meio ambiente sadio.

Corroborando esta previsão de competência comum, no capítulo específico da Constituição Federal sobre o Meio Ambiente (artigo 225), foi imposto ao "Poder Público" o dever de preservar o meio ambiente. Referida expressão tem nítido caráter genérico, de modo que muito bem representa essa incumbência comum de todos os entes federados na defesa do ambiente. Por isso, pode-se dizer que os artigos supracitados complementam-se mutuamente, determinando a necessidade do agir estatal em todos os seus níveis para a completa salvaguarda do ambiente.

Para tanto, conforme já mencionado em capítulo anterior, foi editada em novembro de 2011 a Lei Complementar n. 140/11, que fixou normas para:

"a cooperação entre a União, os Estados, o Distrito Federal e os Municípios nas ações administrativas decorrentes do exercício da competência comum relativas à proteção das paisagens naturais notáveis, à proteção do meio ambiente, ao combate à poluição em qualquer de suas formas e à preservação das florestas, da fauna e da flora."

Referida lei complementar veio para regular a coordenação das ações em prol do meio ambiente por todos os entes da Federação, de modo a possibilitar convênios, acordos de cooperação técnica, delegação de atribuições, descentralização dos encargos, entre outros instrumentos. Como ainda há pouco tempo de vigência desta lei, não é possível falar nos efeitos concretos das mudanças, mas aguarda-se que a proteção do meio ambiente possa ser mais bem efetivada com os novos parâmetros e instrumentos previstos.

Não se pode esquecer, todavia, que a atuação conjunta descoordenada pode ser mais prejudicial ao meio ambiente do que se fosse atribuída tão 
somente a um ente. Por isso, Paulo Affonso Leme Machado criticava em parte a competência comum, mesmo antes da edição da Lei Complementar:

"O perigo da simultaneidade de competências para a implementação do controle ambiental é que todos os entes federados ficaram competentes, mas nenhum deles tem assumido especificamente a melhoria da qualidade das águas, do ar e do solo e nenhuma instância governamental se responsabiliza pela conservação das florestas e da fauna." ${ }^{29}$

Outro problema decorrente da competência comum para o tratamento das questões ambientais se dava no conflito entre os próprios órgãos integrantes do SISNAMA. Paulo de Bessa Antunes recorda que "existe um avanço dos órgãos federais sobre os estaduais e municipais, de maneira cada vez mais insinuante". 30

Para tentar solucionar tal questão, o Decreto 6.514/08 prevê em seu artigo 12 que o pagamento de multa por infração ambiental imposta pelos Estados ou Municípios "substitui a aplicação de penalidade pecuniária pelo órgão federal, em decorrência do mesmo fato". Assim, quando houver aplicação de multa por diversos agentes públicos de fiscalização ambiental, o ente inferior terá prioridade no recebimento de tais valores, haja vista que é afetado diretamente em seu território e terá que suportar as consequências do dano ambiental ocorrido.

O que se busca, portanto, é que haja uma adequada coordenação de tarefas de proteção do meio ambiente por todos os entes, sendo certo que será preciso muito esforço de todo o poder público. Nesse sentido, não pode ser olvidado que tal incumbência constitucional acaba por incluir a atuação do ente municipal na produção de normas locais para cumprir a contento seu mister.

Certamente os Municípios deverão prever restrições adicionais se forem necessárias para o resguardo do meio ambiente local, chegando até mesmo a se cogitar a possibilidade de contrariar legislações estaduais e federais mais permissivas, que muitas vezes não podem atentar para uma questão peculiar de determinado local que merece melhor proteção.

\footnotetext{
${ }^{29}$ MACHADO, Paulo Affonso Leme. Op. cit. p. 124.

30 ANTUNES, Paulo de Bessa. Op. cit. p. 105.
} 
Assim, Paulo de Bessa Antunes sintetiza muito bem a questão: "se a Constituição estabeleceu uma obrigação de cuidado, necessariamente autorizou a produção de normas para que o cuidado pudesse ser exercido". 31

Além dessa competência legislativa ambiental implícita, devem-se analisar as competências legislativas dos artigos 22 e 24 da Constituição. O primeiro insere alguns temas ambientais "lato sensu" na competência privativa da União, enquanto o segundo faz a inserção da proteção do meio ambiente no rol das competências concorrentes, autorizando expressamente a produção de normas pela União e pelos Estados.

A previsão da competência privativa da União para legislar sobre energia, atividades nucleares, jazidas, minas, outros recursos minerais, águas, entre outros temas correlatos ao meio ambiente, faz parecer que a Constituição Federal elegeu tais temas como prioritários da nação, devendo necessariamente sofrer tratamento uniforme no território brasileiro.

No entanto, tal justificativa aparente não é suficiente para convencer a maior parte da doutrina a respeito desta necessidade em dar privatividade à União em referidos assuntos. Sintetizando tais questionamentos, têm-se as palavras de Paulo Affonso Leme Machado:

"Sob o ponto de vista da eficiência legiferante, parece-me difícil que a legislação federal privativa nos setores indicados tenha melhor desempenho do que se fosse inserida na competência concorrente. Da forma como está, os Estados e os Municípios não podem suplementar as deficiências dessas normas federais, como, também, não têm atribuições diretas para adaptar essas normas às suas peculiaridades regionais e locais". ${ }^{32}$

O mais importante, todavia, é que foi inserida junto à competência concorrente a maior parte da tutela ambiental constitucional. Entre elas, se destaca a previsão de legislação sobre "florestas, caça, pesca, fauna, conservação da natureza, defesa do solo e dos recursos naturais, proteção do meio ambiente e controle da poluição", a "proteção ao patrimônio histórico, cultural, artístico, turístico e paisagístico" e a

\footnotetext{
${ }^{31}$ ANTUNES, Paulo de Bessa. Op. cit. p. 106.

${ }^{32}$ MACHADO, Paulo Affonso Leme. Op. cit. p. 387
} 
"responsabilidade por dano ao meio ambiente" (artigo 24, incisos VI, VII e VIII, respectivamente).

Conforme já foi tratado em capítulo específico, a competência concorrente pressupõe que haverá normas gerais, diretrizes, bases estabelecidas pela União, ao passo que aos Estados caberá a suplementação de tais normas.

Assim, com relação à legislação de proteção ambiental, aguarda-se que a União edite as normas gerais e estabeleça as políticas nacionais, de modo a cumprir seu papel principiológico. Dessa maneira, efetivar-se-á a garantia da existência de pisos mínimos de proteção ambiental por meio desta legislação federal.

Paulo de Bessa Antunes, ao tratar do tema, assevera que "há a necessidade de que a legislação de proteção ao meio ambiente assegure níveis nacionais mínimos de tutela ambiental, evitando-se que a possibilidade de poluir mais seja um diferencial competitivo entre os estados e municípios". 33

Nesse sentido, a previsão de normas gerais conferirá um primeiro passo na efetivação da proteção ambiental, pois como lembra Celso Antonio Pacheco Fiorillo, após a fixação de tais bases os "Estados e Municípios jamais poderão legislar de modo a oferecer menos proteção ao meio ambiente". ${ }^{34}$ Por isso, tais entes menores serão legítimos para fixar um teto de proteção, baseado nos seus interesses regionais/locais.

Para que tal sistemática funcione, necessariamente deverá haver cooperação dos entes para a salvaguarda integral do meio ambiente, pois a União não esgotará os assuntos, mas sim tratará das normas com interesses amplos, que afetem todo o País ou pelo menos grande parte deste.

Em caso de inexistência de tais leis federais a respeito de uma matéria específica, já foi visto que os entes inferiores poderão suprir a ausência da norma por meio do exercício da competência legislativa supletiva, produzindo normas gerais válidas em seus respectivos territórios.

Havendo legislação federal, será de suma importância a competência suplementar dos Estados e Municípios, haja vista que estes entes estão sempre mais próximos às suas realidades locais, podendo aumentar a proteção ambiental dos respectivos

\footnotetext{
${ }^{33}$ ANTUNES, Paulo de Bessa. Op. cit. p. 165.

${ }^{34}$ FIORILLO, Celso Antonio Pacheco. Curso de direito ambiental brasileiro. $10^{\text {a }}$ edição. São Paulo: Saraiva. 2009, p. 131
} 
territórios sempre que necessário. Só assim será garantido o atendimento conjunto de uma proteção nacional mínima sem retirar o interesse dos entes inferiores em efetivar a defesa do meio ambiente em sua extensão necessária.

Desse modo, pode-se concluir que o cenário ideal da produção de leis para proteger o meio ambiente se dará quando a União prioritariamente estabelecer os princípios, as diretrizes, as regras nacionais uniformemente aplicáveis, enquanto os Estados e Municípios farão a suplementação dessas normas gerais, em favor da efetiva tutela de seus interesses ambientais.

Certamente será necessário que os Estados e Municípios passem a assumir um papel de maior relevância na elaboração de legislação para implementar suas políticas e restrições ambientais. Apesar de haver algumas iniciativas de leis, que serão melhor tratadas em capítulo específico, parece que ainda há certa resistência com relação a essa normatização estadual/municipal. Tal fato acaba por refletir na atuação desses entes, que ainda está muito aquém de suas capacidades, e, consequentemente, não se situam num patamar condizente com as necessidades de proteção do meio ambiente local e da saúde pública das sociedades envolvidas.

Apesar das críticas que a descentralização da normatização ambiental possa receber, importante mencionar nesta discussão a lição-síntese de Paulo Affonso Leme Machado:

"Não reivindicamos para o Brasil a debilitação do Estado federal. Entendemos de real importância que a normatização fundamental para o meio ambiente seja feita pela União, através de normas gerais; mas que com isso não se anule o Município.”35

Em suma, nos parece claro que o que a Constituição Federal busca, como finalidade precípua da divisão da competência ambiental, que sempre se possibilite a atuação tanto da União como a dos Estados e Municípios. Somente com a observação das leis dos diferentes entes é que se poderá aferir a norma com mais eficácia na proteção do meio ambiente, seja esta norma federal, estadual ou municipal. Por isso, imprescindível será a atuação de todo o "Poder Público" para cumprir tal mandamento constitucional.

\footnotetext{
${ }^{35}$ MACHADO, Paulo Affonso Leme. Op. cit. p. 388.
} 


\subsection{Princípios norteadores da competência ambiental}

\subsubsection{O princípio da predominância do interesse}

O princípio da predominância do interesse é o que norteia a repartição das competências entre os entes federados. De acordo com esse princípio, serão incumbidas à União todas as matérias de predominante interesse nacional, isto é, aquelas matérias que necessitam de um regramento uniforme por haver um interesse geral da nação sobre os mesmos.

Já os Estados seriam responsáveis pelos assuntos de interesse regional, ou seja, aqueles que não chegam a ser nacionais, mas ao mesmo tempo transpassam os interesses meramente locais.

Por último, aos Municípios seriam afetas as matérias de nítido interesse local. Essa sintética divisão baseia-se na predominância do interesse, que é o norte do pacto federativo nacional.

Apesar de a distinção estar formalmente bem delineada, não se pode olvidar a grande dificuldade no estabelecimento de uma distinção profunda entre os interesses supramencionados.

José Afonso da Silva compreende muito bem esse empecilho e sintetizou a questão em breves palavras: "no Estado moderno, se torna cada vez mais problemático discernir o que é interesse geral ou nacional do que seja interesse regional ou local.",36

Como se pode imaginar, na seara ambiental as dificuldades são ainda maiores, pois o meio ambiente é um bem de uso comum do povo e a qualidade ambiental afeta a cada um e a todos indistintamente. Assim, é demasiadamente difícil delinear quais temas ambientais poderiam pertencer mais à esfera local, regional ou nacional.

Diante da complexidade de problemas como esse, a doutrina moderna trouxe mais um princípio para nortear à repartição das competências constitucionais, qual seja, o princípio da subsidiariedade, que se passa a examinar.

\footnotetext{
${ }^{36}$ SILVA, José Afonso da. Op. cit. p. 478.
} 


\subsubsection{Princípio da subsidiariedade e o direito comparado}

No tratamento da divisão das competências constitucionais, também se pode mencionar o princípio da subsidiariedade, o qual está historicamente baseado num direito natural do homem de tomar suas decisões em sua comunidade, pois teria recebido da natureza o direito de viver e proteger sua espécie, muito antes da existência do próprio Estado. O conteúdo moderno do princípio está fundado na doutrina social da Igreja e em Encíclicas, que já postulavam que deveria ser dada maior atenção ao tratamento local das questões $^{37}$.

O princípio da subsidiariedade pode ser analisado sob dois aspectos: o vertical e o horizontal. Pela ótica vertical, entende-se que, na distribuição de competência, só deveria haver maior influência da União quando fosse necessário, isto é, quando os Estados-membros não pudessem realizar suas ações de forma suficiente. Já pela ótica horizontal, busca-se uma primazia da atuação da iniciativa privada, de modo que o Estado só deveria agir residualmente. Além disso, é buscada uma atuação com mais proximidade ao cidadão, seja pelo órgão público ou pelo privado, bem como se busca que essa tarefa seja realizada pelo órgão que possa desempenhá-la com maior eficiência.

Para a presente dissertação, tem maior importância o enfoque da subsidiariedade na ótica vertical, quando é relacionada a um princípio norteador da repartição de competências, baseado na cooperação entre os entes federativos. Tal cooperação seria realizada, em certos casos, com a primazia do ente menor na realização das tarefas comuns, enquanto que a entidade maior só interviria quando fosse necessário.

Assim, percebe-se que referido princípio auxilia na repartição de competências dentro da esfera estatal, buscando assegurar liberdade e autonomia aos entes que a compõem, ganhando especial relevo nos países que adotam a Federação como forma de Estado.

No Brasil, vislumbra-se uma incorporação implícita do princípio da subsidiariedade no texto constitucional, em razão do modo como foi feita a repartição de competências somada ao fortalecimento municipal. A inclusão do Município como ente da

${ }^{37}$ CASTRO, José Nilo de. Op. Cit. p. 378. 
Federação demonstra a opção da Constituição por uma descentralização política, o que está em consonância com a ideia do princípio da subsidiariedade na repartição das competências constitucionais. Isso também se coaduna com o fortalecimento do pacto federativo estabelecido pela Carta Magna, como mencionado no capítulo sobre a Federação brasileira.

Portanto, com o advento da Constituição Federal de 1988, a tendência municipalista verificada corrobora a utilização do princípio da subsidiariedade, especialmente quando relacionado à questão ambiental. Tratando de meio ambiente, a Carta Magna outorgou competência material comum, competência legislativa concorrente, assim como impôs o dever de todo o Poder Público na defesa e proteção do meio ambiente.

Nessa confluência de atribuições, deve-se garantir grande relevo para a atuação do Município, o que pode ser muito favorável às crescentes demandas pela proteção ambiental. A possibilidade deste ente também produzir normas visando a melhoria da qualidade ambiental de seu território se mostra uma alternativa hábil para o cumprimento de suas atribuições constitucionais. Isso porque, sendo o ente que toma suas decisões de forma mais próxima das pessoas, certamente haverá maior influência da população, construindo uma cidadania participativa em prol do meio ambiente local.

Nesse sentido, pode-se pensar numa reinterpretação da competência legislativa em matéria ambiental, de forma a favorecer a primazia do Município frente ao Estado e à União. Esta interpretação privilegia a tomada de decisões partindo justamente do ente federado mais próximo dos cidadãos. Referida proximidade tem grandes chances de garantir uma maior efetividade à sustentabilidade do meio local, pois quanto mais conhecedor da realidade do ambiente, mais fácil será o enfrentamento dos problemas dos munícipes.

Assim, a União trataria somente do cumprimento das questões nas quais os entes inferiores não teriam o mesmo êxito na execução de tais tarefas. De outro lado, as autoridades com maior contato com a população poderiam executar o interesse público de forma a atender melhor os anseios da comunidade.

Tratando do princípio da subsidiariedade, Paulo de Bessa Antunes entende que:

"O objetivo fundamental do princípio é a construção de parâmetros que sejam capazes de limitar a atuação do Estado e de lhe impor obstáculos 
sempre que, nos casos concretos, as soluções dos problemas sejam mais bem encaminhadas pela própria sociedade mediante a atuação de seus diferentes agentes". 38

De maneira ainda mais enfática, o autor chega a asseverar que "passar para a sociedade maior e mais elevada o que sociedades menores e inferiores podiam conseguir é uma injustiça, um grave dano e perturbação da ordem social"39.

Nesse sentido fundamenta-se o princípio da subsidiariedade, segundo o qual o ente federativo superior só deve atuar se o ente inferior não estiver em condições adequadas de exercê-las eficazmente. A idéia do princípio seria justamente privilegiar a atuação do Município, sob o fundamento de que estando mais próximo dos cidadãos, poderia garantir mais efetividade aos anseios da sociedade.

Em matéria ambiental, sendo o ente local o maior conhecedor de seu território, das vontades e dos valores da sociedade, parece certo que o Município poderia dar um tratamento mais restritivo a certas questões ambientais que afetem negativamente seus munícipes, protegendo também os bens ambientais de seu território. Já as entidades superiores cooperariam com este, numa atuação subsidiária de ajuda nas áreas que o ente menor estivesse com dificuldades.

Dessa maneira, deve-se buscar uma interpretação da Federação brasileira de modo a garantir primazia ao Município, haja vista que este ente está mais próximo da população e por isso pode melhor desempenhar as funções públicas com vistas à busca do equilíbrio ecológico local e à melhoria da qualidade de vida das pessoas.

Todo esse fortalecimento da gestão ambiental pelo Município está em consonância com os preceitos trazidos pelo princípio da subsidiariedade, de modo que poderá haver uma maior efetividade das normas que buscam cumprir os desígnios estabelecidos na Constituição Federal de 1988, especialmente em seu artigo 225.

Assim, o referido princípio está assentado na ideia de assegurar uma maior eficácia na distribuição de competências, especialmente naquelas que devam ser realizadas por todos os entes federados e que possam gerar conflitos, como é o caso do meio ambiente. Diante de tal realidade, Jusara Aparecida Bratz, em aprofundado estudo sobre o tema, demonstra que: "Para solução de tais conflitos, surge o princípio da

\footnotetext{
${ }^{38}$ ANTUNES, Paulo de Bessa. Op. cit. p. 176.
}

${ }^{39}$ ANTUNES, Paulo de Bessa. Op. cit. p. 178 
subsidiariedade, (...) que preconiza ser injusto e ilícito adjudicar a uma sociedade maior o que é ainda capaz de fazer com eficácia uma sociedade menor" ${ }^{\prime 40}$.

Ocorre que isso não significa que todas as atribuições devem recair exclusivamente ao ente menor, sendo que o princípio da subsidiariedade serve como parâmetro interpretativo para as situações em que não haja competência exclusiva expressa em favor de algum dos entes federados. Assim, para a adequada utilização de referido princípio, deve-se verificar, primeiramente, que referida matéria não seja da competência exclusiva de algum dos entes. Após, deverá se certificar-se que o ente inferior terá condições de realizar com eficácia suas atribuições. Caso não possa realizar de modo satisfatório sua função, o ente superior deverá buscar auxiliar o primeiro, cooperando, atuado de modo complementar.

No tratamento da competência administrativa ambiental, é sempre citado o regramento do licenciamento das atividades potencialmente poluidoras, no qual os entes menores têm primazia para realizar a tarefa. A atuação do IBAMA (Instituto Brasileiro do Meio Ambiente e dos Recursos Naturais Renováveis), representando o ente federal, deverá ser feita somente em situações excepcionais ${ }^{41}$, tratadas atualmente na Lei Complementar 140/11. Para as demais hipóteses, os entes inferiores que são competentes para o licenciamento.

A tomada de decisões pela esfera mais próxima dos cidadãos realça a necessidade da cidadania e do poder-dever cívico de cada munícipe. O Município é a unidade política primária - anterior ao próprio Estado - originando-se pela necessidade do homem de viver coletivamente.

40 BRATZ, Jusara Aparecida. Competência do município para legislar em matéria ambiental à luz do princípio da subsidiariedade. Belo Horizonte: Revista interesse público, nº 67, ano XIII, maio/junho 2011, p. 272.

${ }^{41}$ Licenciamento de empreendimentos e atividades: localizados ou desenvolvidos conjuntamente no Brasil e em país limítrofe; localizados ou desenvolvidos no mar territorial, na plataforma continental ou na zona econômica exclusiva; localizados ou desenvolvidos em terras indígenas; localizados ou desenvolvidos em unidades de conservação instituídas pela União, exceto em Áreas de Proteção Ambiental (APAs); localizados ou desenvolvidos em 2 (dois) ou mais Estados; de caráter militar, excetuando-se do licenciamento ambiental, nos termos de ato do Poder Executivo, aqueles previstos no preparo e emprego das Forças Armadas, conforme disposto na Lei Complementar $\mathrm{n}^{\mathrm{o}}$ 97, de 9 de junho de 1999; destinados a pesquisar, lavrar, produzir, beneficiar, transportar, armazenar e dispor material radioativo, em qualquer estágio, ou que utilizem energia nuclear em qualquer de suas formas e aplicações, mediante parecer da Comissão Nacional de Energia Nuclear (Cnen); ou que atendam tipologia estabelecida por ato do Poder Executivo, a partir de proposição da Comissão Tripartite Nacional, assegurada a participação de um membro do Conselho Nacional do Meio Ambiente (Conama), e considerados os critérios de porte, potencial poluidor e natureza da atividade ou empreendimento. 
Parece mais natural que as decisões a respeito da proteção ambiental possam ser feita pelos cidadãos, sem embargo da uniformização da proteção mínima pelos entes superiores. Por isso, busca-se, nos dizeres de Paulo de Bessa Antunes, "uma descentralização que seja capaz de executar com mais eficiência determinadas medidas". ${ }^{4}$ O que puder ser mais bem realizado no nível comunitário deve ser lá feito, deixando o poder local com preferência no tratamento das questões ambientais.

Somente com a formulação de políticas públicas ambientais bem estruturadas poder-se-á implementar um meio ambiente ecologicamente equilibrado que proporcione a tão almejada sadia qualidade de vida. E por estar mais próximo dos cidadãos, o Município encontra-se mais apto a buscar soluções adequadas para os problemas ambientais que afligem o meio local.

Conforme já adiantado, deve-se tomar cuidado para que não haja o desvirtuamento dos ideais do princípio da subsidiariedade quando relacionado à proteção ambiental. Isto porque, conforme assentado na doutrina ambientalista, propugna-se a atuação legislativa dos entes inferiores para aumentar a tutela do meio ambiente, mas nunca para diminuí-la. Essa ressalva é importante para se impedir as tentativas de alguns Municípios e até Estados da Federação que buscaram suprimir os pisos mínimos de proteção ambiental estabelecidos pela União.

Ora, não se pode aceitar que interesses meramente econômicos, normalmente buscando diminuir custos das atividades agrárias ou industriais, desconsiderem o mínimo da proteção ambiental garantida por lei federal. Como é sabido, as áreas protegidas por lei federal têm certas finalidades específicas.

No Código Florestal, por exemplo, explicita-se que as áreas de preservação permanente buscam "preservar os recursos hídricos, a paisagem, a estabilidade geológica e a biodiversidade, facilitar o fluxo gênico de fauna e flora, proteger o solo e assegurar o bem-estar das populações humanas"43; já a instituição da reserva legal seria necessária para "assegurar o uso econômico de modo sustentável dos recursos naturais do imóvel rural, auxiliar a conservação da biodiversidade, bem como o abrigo e a proteção de fauna silvestre e da flora nativa",44.

\footnotetext{
${ }^{42}$ ANTUNES, Paulo de Bessa. Op. cit. p. 187.

${ }^{43}$ Artigo $3^{\circ}$, inciso II, da Lei $n^{\circ} 12.651 / 2012$.

${ }^{44}$ Artigo $3^{\circ}$, inciso III, da Lei $\mathrm{n}^{\mathrm{o}} 12.651 / 2012$.
} 
A proteção uniforme dessas áreas protegidas não poderia sofrer minimizações locais, haja vista que a lei nacional buscou estabelecer os patamares mínimos de proteção. O que aqui se advoga, portanto, seria a possibilidade dos demais entes federados, buscando atender suas peculiaridades locais, aumentar os referenciais básicos estabelecidos na lei federal.

Na prática, parece que o princípio da subsidiariedade fixa as bases de um sistema complexo de competências ambientais nas quais à União caberá a fixação de pisos mínimos de proteção ao meio ambiente, enquanto os Estados e Municípios poderão criar um "teto" de proteção, sempre em atenção aos seus interesses regionais e locais.

Este modelo de primazia do ente local para decidir se aumenta ou não as restrições ambientais de seu território não é uma inovação do sistema brasileiro. Quando se estuda as normas ambientais no Direito Comparado, percebe-se que em muitos países tal sistemática tem sido adotada.

O Tratado de Maastricht, que foi responsável pela evolução da Comunidade Econômica Europeia em União Europeia, certamente é um dos mais importantes documentos legais que adota o princípio da subsidiariedade ${ }^{45}$.

$\mathrm{Na}$ Espanha, por exemplo, a legislação com os princípios e bases da proteção ambiental é feita pelo próprio Estado, deixando o estabelecimento de regras mais protetivas como uma faculdade às Comunidades Autônomas. Quanto ao tema, Paulo Affonso Leme Machado revela que "Essas regras adicionais podem traduzir-se no estabelecimento de medidas mais rigorosas contra a poluição de restrições mais severas para o uso de veículos, de limitações mais fortes para certas indústrias ou para as atividades turísticas, etc. ${ }^{, 46}$

O que não se admite, todavia, é que as Comunidades Autônomas enfraqueçam as normas de proteção ambiental já fixadas pelo Estado, haja vista que tal possibilidade seria uma deturpação da utilização do princípio da subsidiariedade. Como visto, referido princípio busca manter a uniformização mínima da proteção ambiental, facultando um acréscimo desta ao ente local, que está mais próximo da realidade e pode perceber mais facilmente a necessidade de legislar de modo mais rigoroso.

\footnotetext{
${ }^{45}$ ANTUNES, Paulo de Bessa. Op. cit. p. 186

${ }^{46}$ MACHADO, Paulo Affonso Leme. Op. cit. p. 114
} 
No mesmo sentido foi o argumento no recurso vencedor da Corte de Arbitragem 47 da Bélgica, ao afirmar que:

"a competência atribuída às regiões em matéria de proteção do ambiente deve ser exercida respeitando-se as normas legais gerais e setoriais, e que, em outros termos, esta disposição não concede às regiões senão o poder de adotar normas mais severas que as normas elaboradas pelo legislador nacional e não o poder de ab-rogar estas últimas". ${ }^{7}$

Passando para a América do Sul, encontra-se semelhante previsão na Constituição da Argentina, de 1994. Conforme se extrai do artigo 41, § $3^{\circ}$, a Nação Argentina ditará as normas contendo os pressupostos mínimos de proteção ambiental, permitindo-se às Províncias a complementação das mesmas.

Tal universalização da proteção ambiental pela Nação Argentina garante um mínimo defesa do meio que deverá ser observado em todo o país. Já as Províncias do país terão a possibilidade de alterar tais normas, sem, contudo, diminuir as restrições protetivas, isto é, poderão ou aceitar o mínimo nacional ou majorá-lo.

Diante desses breves exemplos que se extraem da análise do princípio da subsidiariedade em outros países, pode-se perceber que faz muito sentido a aplicação prática desta lógica protetiva. Até porque a competência dos Municípios para legislar sobre o meio ambiente não só vai ao encontro do viés protetivo da Constituição Federal, como também favorece a melhoria da qualidade ambiental desses locais.

Portanto, no estudo dos princípios que tratam da repartição das competências constitucionais se mostra necessário uma conjugação do princípio da subsidiariedade com o critério da predominância do interesse, pois este se mostrou insuficiente para resolver, de forma isolada, os conflitos de competência, notadamente quando se trata de matéria ambiental.

Assim, de um lado, a fixação das bases de proteção pelo ente superior garante um mínimo de defesa do meio ambiente necessário para todo o País. De outro lado, a possibilidade de aumentar as restrições pelos entes inferiores permite não só a melhor adequação das leis em face dos bens ambientais a serem protegidos, como também assegura um maior respeito à deliberação da comunidade em face dos riscos dos danos ambientais que aceitam suportar.

\footnotetext{
${ }^{47}$ In MACHADO, Paulo Affonso Leme. Op. cit. p. 114.
} 
Só assim parece que se está dando cumprimento aos ditames da Constituição brasileira, a qual garante em seu artigo 225 o direito de todos ao meio ambiente ecologicamente equilibrado e essencial à sadia qualidade de vida. A busca de tais preceitos genéricos dar-se-á com a adequação das normas ambientais em cada realidade local, possibilitando-se uma mais efetiva defesa do meio ambiente e também uma maior proteção da saúde pública.

\subsection{Repartição da competência legislativa ambiental}

\subsubsection{O papel da União na competência ambiental}

Tratando-se de competência legislativa concorrente, especificamente sobre matéria ambiental, a União somente deverá editar normas gerais, isto é, apenas as linhas gerais, os princípios ou os critérios básicos a serem observados pela legislação suplementar dos Estados.

A União, nessas matérias, pode legislar com maior ou menor amplitude, conforme queira impor a todo o País uma legislação mais ou menos uniforme. O que a União não pode é legislar sobre assuntos particulares da esfera de interesses ou de peculiaridades dos Estados. Assim, tais normas gerais contrapõem-se às normas particulares, ou seja, terão de ser normas uniformes, isonômicas, aplicáveis a todos os cidadãos e a todos os Estados da Federação, sem peculiaridades.

No entanto, a Constituição Federal não especificou exatamente os limites de tais normas gerais, deixando esta tarefa à doutrina e à jurisprudência. Diante da dificuldade em se precisar o significado de termo tão abrangente, será necessário auxílio dos estudiosos da teoria geral do direito.

De acordo com Tércio Sampaio Ferraz Junior ${ }^{48}$ :

“(...) [quando o texto constitucional atribui] à União competência para legislar sobre "normas gerais", a linguagem constitucional pode estar tratando de normas gerais pelo conteúdo, ou de normas universais, isto é,

${ }^{48}$ FERRAZ Jr, Tércio Sampaio. Normas gerais e competência concorrente - uma exegese do art. 24 da Constituição Federal. São Paulo: Malheiros, Revista trimestral de direito público, nº 7, 1994, p. 18/19. 
gerais pelo destinatário (...) quanto ao conteúdo, normas gerais prescrevem princípios, diretrizes sistemáticas, temas que se referem a uma espécie inteira e não a alguns aspectos, mas isto é insuficiente para reconhecer quando estamos diante de uma norma geral ou de uma particular. Sempre restarão dúvidas, no caso concreto, para aplicar o critério estritamente lógico-formal."

Em minucioso estudo a respeito de qual seria o conceito de normas gerais, Denise Vasques compilou algumas das definições de renomados autores, haja vista que: "Não é novidade anunciar que a definição de um conceito apriorístico para normas gerais é tarefa árdua e praticamente desprovida de êxito. Muitas foram as tentativas doutrinárias, desde a introdução do conceito, pela primeira vez, na Constituição de 1934,49 .

A partir de tal ressalva, a autora passa a mencionar diversos posicionamentos de doutrinadores a respeito do tema. Relembra que Fabio Fanicchi relaciona normas gerais àquilo que tenha um interesse geral ao País, isto é, aquilo que não se encaixasse nos interesses regionais ou locais ${ }^{50}$. Já citando a visão de Raul Machado Horta, a autora afirma que as "normas gerais são aquelas que não esgotam, por completo, determinado assunto" ${ }^{, 51}$. Finalmente, assevera a autora que Manoel Gonçalves Ferreira Filho, "ao conceituar sobre normas gerais, prefere empregar método negativo, de exclusão, com a indicação do que for particular ou específico" 52 .

Diante dessas citações, a autora percebe que "muitas normas irão pertencer a uma esfera cinzenta ou zona de indeterminação, na qual o subjetivismo do intérprete poderia levar à caracterização do preceito como norma geral ou como norma específica" ${ }^{53}$. Portanto, sempre haverá casos nos quais irá pairar dúvida a respeito de até onde uma norma estará tratando de algo geral e a partir de quando ela estaria já adentrando numa particularidade.

Assim, em que pese ser possível a divisão teórica entre normas gerais e normas específicas, o subjetivismo do intérprete sempre será decisivo quando da

${ }^{49}$ VASQUES, Denise C. Competências legislativas concorrentes: prática legislativa da União e dos Estados-membros e jurisprudência do Supremo Tribunal Federal. Dissertação de Mestrado à Faculdade de Direito da Universidade de São Paulo sob orientação do Prof. Elival da Silva Ramos, 2007, p.55.

${ }^{50}$ VASQUES, Denise C. Op. Cit. p. 55.

${ }^{51}$ VASQUES, Denise C. Op. Cit. p. 56.

${ }^{52}$ VASQUES, Denise C. Op. Cit. p. 56.

${ }^{53}$ VASQUES, Denise C. Op. Cit. p. 57. 
análise de legislações que pertençam a esta zona cinzenta, indeterminada. Por isso, inevitáveis serão os conflitos de competência, notadamente nas leis ambientais.

Diante de cada caso concreto, deve-se buscar a verificação da existência ou não de prevalência das normas gerais em relação às locais/regionais que eventualmente dispuserem de modo diverso da norma federal.

Paulo de Bessa Antunes entende "que as competências privativas da União têm precedência sobre todas as outras formas de competência, quando os assuntos tiverem entre si interseções relevantes" ${ }^{54}$. O autor faz parte da doutrina que defende que a normatização geral sempre prevalece, sob argumento de que os interesses nacionais seriam mais importantes que os demais. Por isso, não seria desarrazoado buscar uma homogeneização do tratamento das questões ambientais em conjunto para todo o País.

O autor ainda complementa:

“(...) competência exclusiva da União (...) muitos dos assuntos incluídos em tal competência estão profundamente inter-relacionados com outros que estão arrolados nas demais modalidades de competência. (...) os tribunais brasileiros (...) têm prestigiado a legislação central." 55

De outro lado, não se poderá negligenciar que tal assunto não é pacífico, pois também é aceito por parte da doutrina o aumento das restrições ambientais pelos entes inferiores. Isto porque a União não poderia, a pretexto da uniformização das leis ambientais, prejudicar o direito dos munícipes de buscarem a tão almejada sadia qualidade de vida.

Nesse sentido, Paulo Affonso Leme Machado afirma que:

"Ao procurar a utilidade nacional, não poderá a União prejudicar concretamente o direito dos munícipes à sadia qualidade de vida e ao meio ambiente ecologicamente equilibrado. Se tal ocorrer, a disposição federal merecerá ser declarada inconstitucional pelo Poder Judiciário" ${ }^{56}$.

Por fim, havendo a instauração de conflitos reais entre normas e sua respectiva judicialização, aguarda-se que o Poder Judiciário esteja preparado para, entre outras finalidades, buscar assegurar o equilíbrio federativo e a necessária proteção do meio ambiente. A materialização deste conflito será mais bem analisada nos exemplos trazidos

\footnotetext{
${ }^{54}$ ANTUNES, Paulo de Bessa. Op.cit. p.107.

${ }^{55}$ ANTUNES, Paulo de Bessa. Op. cit. p. 180.

${ }^{56}$ MACHADO, Paulo Affonso Leme. Op. cit. p. 390.
} 
nos capítulos seguintes, por meio dos casos nas quais houve a interposição de Ações Diretas de Inconstitucionalidades contra leis municipais e até estaduais que buscaram tutelar o meio ambiente de maneira mais protetiva. Conforme será visto, a principal alegação para a inconstitucionalidade seria a suposta invasão da competência da União para a edição das normas.

\subsubsection{O papel dos Estados na competência ambiental}

Para analisar o papel dos Estados na competência legislativa ambiental, deve-se observar que as atribuições deste ente em relação às Constituições anteriores foram alargadas, na medida em que o novo tratamento constitucional previu competências exclusivas, concorrentes, suplementares e supletivas.

Especificamente tratando de meio ambiente, a Constituição Federal de 1967 não trazia disposições conjuntas sobre o tema, diferentemente de hoje que há o artigo 225, que é um capítulo próprio para a tutela ambiental. Além disso, todos os temas relacionados ao meio ambiente eram de competência da União, de modo que os Estados não possuíam qualquer competência sobre essa matéria, nem mesmo de forma complementar.

No caso do artigo 24 da atual Constituição Federal, que trata da competência legislativa concorrente, houve um aumento das matérias sobre as quais os Estados têm a incumbência de editar leis.

Fernanda Dias Menezes de Almeida muito bem explicita o tema:

"Abrir aos Estados uma esfera de competências legislativas concorrentes, em que lhes é facultado, por direito próprio, e dentro dos limites traçados pela Constituição, disciplinar uma série de matérias que antes escapavam de sua órbita de atuação legiferante, significa, por certo, ampliar-lhes os horizontes e incentivar-lhes a criatividade" 57 .

Muitos passaram a advogar a tese de que os Estados, na repartição de competências, deveriam ter as maiores incumbências com que fossem capazes de lidar,

\footnotetext{
${ }^{57}$ ALMEIDA, Fernanda Dias Menezes de. Op. cit. p. 61.
} 
deixando para a União somente o que realmente fosse exclusivo do ente federal. Inclusive, fala-se hoje no princípio da "imprescindibilidade das competências da União", de modo que o ente federal teria um papel subsidiário, concentrando seus esforços nas matérias que demandassem um tratamento unitário nacional.

Isso porque, no Estado Federal, são os Estados que cedem parcela de sua soberania para a União, preservando-se, porém, sua autonomia. Portanto, os entes Estaduais somente transfeririam para o ente federal aquelas competências que fossem imprescindíveis para este ente.

Por outro lado, Luiz Fernando Coelho busca esclarecer que essa competência Estadual também não é ilimitada, de modo que menciona algumas mitigações que devem ser observadas: "Lei estadual pode estabelecer limitações ao exercício dos direitos, com vistas à proteção ambiental, ainda que não previstas na legislação federal, desde, é claro, que tais restrições sejam compatíveis com as liberdades públicas constitucionais" 58 .

A par disso, pode-se verificar que os Estados permaneceram com sua competência para complementar as demais normas, somente sendo substituído este termo pela expressão 'suplementar'.

Portanto, no seu poder-dever de suplementação, os Estados devem precipuamente buscar o aperfeiçoamento das normas gerais estabelecidas pela União. Referidas normas suplementares deverão desdobrar, isto é, detalhar as normas federais de caráter genérico.

Além disso, verifica-se que a grande novidade da Constituição Federal de 1988 para com os Estados foi a criação da possibilidade deste ente editar normas gerais nas matérias em que a União ainda não as tenha feito, conforme expressamente previsto no artigo $24, \S 3^{\circ}$ da Constituição Federal.

Referida competência foi denominada de supletiva, pois permite ao Estado que legisle plenamente sobre determinada matéria. Como o próprio nome sugere, suprir é muito mais amplo que suplementar, de modo que neste caso os Estados-membros deverão editar as normas gerais e as normas específicas sobre determinada matéria.

58 COELHO, Luiz Fernando. A competência concorrente em direito ambiental. Brasília: Revista de informação legislativa do Senado Federal, n 114, ano 29, abril/junho, 1992, p. 71. 
Assim, enquanto o termo complementar, que foi substituído por suplementar, indica que o Estado pode trazer normatizações para além daquelas já traçadas pela União, o verbo "suprir", correspondente a competência supletiva, assegura ao Estado que este pode substituir a União nas normas gerais, sempre que houver omissão desta última.

Assim, pode-se sintetizar a repartição da competência concorrente entre a União e os Estados nos dizeres Paulo de Bessa Antunes:

“a União (...) somente pode estabelecer normas gerais, cabendo aos Estados minudenciar os aspectos da proteção ambiental em concreto. Os Estados podem suplementar a legislação federal. (...) se inexistente a norma federal, os Estados exercerão a competência legislativa plenamente" 59 .

$\mathrm{Na}$ atividade supletiva, as Leis estaduais terão validade no respectivo território, e, conforme preceitua o $\S^{\circ}$ do artigo 24 da Constituição Federal, a superveniência de normas gerais feita pela União suspenderá a eficácia das normas estaduais. Isto porque, a faculdade atribuída ao Estado de legislar na omissão da União não retira deste ente sua competência para tanto, de modo que poderá ser feita lei posterior pela União a qualquer tempo.

Fernanda Dias Menezes de Almeida trata muito bem deste tema:

"É natural que assim seja. (...) ao admitir a competência supletiva estadual, a Constituição não despoja a União de sua competência primária de editar normas gerais. Apenas provê para que os Estados possam desempenhar atribuições obstadas pela ausência de regulamentação federal. No momento, porém, em que a titular primeira da competência decide exercê-la, prevalecerá o direito federal" 60

Assim, caso haja a edição superveniente da norma geral da União, a Constituição Federal prevê que haverá a suspensão da eficácia dos dispositivos que forem contrários aos ditames da lei federal, mas não haverá revogação da Lei Estadual (artigo 24, $\left.\S 4^{\circ}\right)$.

Paulo Affonso Leme Machado ainda observa que os Estados devem observar as normas gerais já estabelecidas, pois deveria haver uma "fidelidade federal": "A

${ }^{59}$ ANTUNES, Paulo de Bessa. Op. Cit. p. 110.

${ }^{60}$ ALMEIDA, Fernanda Dias Menezes de. Op. Cit. p. 138. 
competência dos Estados para legislar, quando a União já editou uma norma geral, pressupõe uma obediência à norma federal" 61 .

No entanto, caso a União extrapole suas normas gerais e acabe ingressando na regulamentação específica de determinada matéria, não há que se falar em hierarquia da União, pois cada ente recebeu competências delimitadas na Constituição Federal, de modo que podem tratar dos temas de que foram incumbidos, não podendo extrapolar.

Assim, com muita razão Fernanda Dias Menezes de Almeida ensina que se deve observar a questão de competências pré-estabelecidas para cada ente: "cada um deles, dentro dos limites definidos, deverá exercer a sua competência com exclusividade, sem subordinação hierárquica. Com a conseqüência de que a invasão do espaço legislativo de um centro de poder por outro gera a inconstitucionalidade da lei editada pelo invasor" 62 .

Além da competência concorrente, os Estados também detêm competência residual para os assuntos não enumerados expressamente na Constituição Federal. Isto porque o $\S 1^{\circ}$ do artigo 25 legitima os Estados-membros a editarem leis sobre todas as matérias que não lhes sejam expressamente vedadas pela Carta Magna.

Finalmente, os $\S \S 2^{\circ}$ e $3^{\circ}$ do artigo 25 ainda trazem matérias que são da competência exclusiva dos Estados, a exemplo da exploração dos serviços locais de gás canalizado, da instituição de regiões metropolitanas, aglomerações urbanas e microrregiões, sempre com vistas à integração da organização e planejamento das funções públicas de interesse comum.

${ }^{61}$ MACHADO, Paulo Affonso Leme. Op. Cit. p. 119.

${ }^{62}$ ALMEIDA, Fernanda Dias Menezes de. Op. Cit. p. 128/129. 


\section{Capítulo 3 - A COMPETÊNCIA DOS MUNICÍPIOS NA LEGISLAÇÃO AMBIENTAL}

\subsection{Evolução da autonomia municipal na Federação}

A importância do Município tem profundas raízes históricas, uma vez que, assim como a família, ele antecede ao Estado. Isso fez alguns doutrinadores buscarem justificar a autonomia municipal como um dos postulados do Direito Natural. ${ }^{63}$

A idéia jusnaturalista se justificaria porque se estaria diante de um direito fundamental que o Estado não cria ou estabelece, mas tão somente reconhece o direito que já pertence aos Municípios. Os franceses são reconhecidos como os criadores do princípio da autonomia municipal, denominado "pouvoir municipal", considerado o mais antigo de todos.

Para introduzir a temática do Município na estrutura político administrativa do Brasil se faz importante a lição de Dalmo de Abreu Dallari: "O Brasil nasceu no município e, durante os primeiros séculos da história brasileira, todos os problemas de interesse comunitário eram resolvidos pela iniciativa particular ou pelo governo municipal" ${ }^{\prime 64}$.

Nesse contexto, desde a divisão do Brasil em sesmarias no século XVI, foi-se instaurando um poder estritamente local, com a presença dos "coronéis" que governavam seus territórios.

No entanto, a partir do século XVIII, com a expansão da atividade de extração de minérios (especialmente do ouro), houve um fortalecimento de um governo central, especialmente para atender aos interesses da Coroa Portuguesa.

\footnotetext{
${ }^{63}$ BONAVIDES, Paulo. Curso de direito constitucional. São Paulo: Malheiros. 2009, p. 351.

${ }^{64}$ DALLARI, Dalmo de Abreu. Meio Ambiente e Município In: Alaôr Caffé Alves; Arlindo Philippi Jr; Marcelo de Andrade Roméro; Gilda Collet Bruna. (Org.). Meio Ambiente, Direito e Cidadania. $1^{\mathrm{a}}$ ed. São Paulo: SIGNUS / NISAM-USP, v.1, 2002, p. 35.
} 
Referido governo de âmbito nacional consolidou-se ainda com maiores poderes já no início do século XIX, notadamente com a vinda da família real em 1808 e mantida com os governos dos imperadores D. Pedro I e II.

Tal centralização se deu de tal forma que o Brasil consistia num Estado Unitário, sob obediência a um poder central moderador instaurado com a Constituição imperial de 1824.

Com as mudanças sociais que culminaram na proclamação da República, buscando assemelhar nosso País ao modelo de maior autonomia local criado pelos norte-americanos, o Brasil foi transformado numa Federação de Estados.

Ocorre que o processo de urbanização e industrialização das cidades do século $\mathrm{XX}$, que deveria favorecer ainda mais os entes municipais, acabou por ser estabelecido no contexto global das grandes guerras mundiais - e posteriormente da guerra fria - de modo que o referido fortalecimento dos Municípios foi acompanhado de uma intensificação do nacionalismo-ufanismo, notadamente nos períodos ditatoriais da era Vargas e dos militares. Assim, em que pese tenha crescido a importância dos Municípios, os ideias de um País com um governo central forte acabou prevalecendo.

Tanto é assim que Dalmo Dallari recorda que:

"Na década de 1960, (...) qualquer município que desejasse construir uma ponte deveria pleitear a inclusão dessa obra no planejamento nacional, sem o que não seriam destinados recursos para sua execução. Tal solução, evidentemente inadequada para o atendimento das prioridades locais, refletia bem a desconfiança nos governantes municipais, considerados incompetentes e provavelmente desonestos." 65

Diante deste brevíssimo comentário histórico, resta demonstrado que o papel do Município acabou por ficar negligenciado em grande parte da história do Brasil. No entanto, atualmente a visão descentralizadora está crescendo cada vez mais, especialmente com o fortalecimento dos ideais municipalistas que têm influenciado o País nas últimas décadas. Um dos maiores reflexos deste novo cenário foi a elevação do Município a ente federativo na Constituição Federal de 1988, de modo que o ente local recebeu um status jurídico nunca dantes obtido em praticamente um século de República Federativa.

\footnotetext{
${ }^{65}$ DALLARI, Dalmo de Abreu. Op. Cit. 2002. p. 35.
} 
Assim, ao consagrar o Município como entidade autônoma no sistema federativo, a Carta Magna implicitamente conferiu-lhes inúmeras competências legislativas, as quais são reflexos da autonomia concedida. Até porque, conforme afirma José Afonso da Silva, "não existe autonomia federativa sem capacidade normativa sobre determinada área de competência" 66 .

O reconhecimento da autonomia local também pode ser visto como um princípio fundamental para a salvaguarda dos interesses mais caros dos munícipes, a exemplo da proteção do meio ambiente, da garantia da saúde pública, entre outros.

Nesse viés, Fiorillo entende que:

"A Carta Constitucional trouxe importante relevo para o Município, particularmente em face do direito ambiental brasileiro, na medida em que é a partir dele que a pessoa humana poderá usar os denominados bens ambientais, visando plena integração social, com base na moderna concepção de cidadania." 67

Se não bastasse, a elevação do Município como um ente autônomo da Federação teria sido inócua se a este não fosse garantida ampla liberdade de legislar, pois, como visto, não existe autonomia federativa sem capacidade normativa. Parece, portanto, que a Constituição Federal de 1988 buscou dar maior importância aos entes municipais, inclusive por meio da possibilidade do tratamento dos problemas locais serem resolvidos pela municipalidade.

Faz jus à democracia porque facilita que as pessoas participem das decisões dos problemas referentes aos respectivos Municípios. Não faria sentido que a esfera federal tivesse que se atentar às peculiaridades dos mais de cinco mil Municípios brasileiros, ao passo que, deixando municipalizadas as decisões, estar-se-á facilitando o respeito aos verdadeiros interesses do povo local.

Assim, em consonância com o sistema federativo então vigente, pode-se inferir que a Constituição alargou a autonomia municipal, dando um "reforço de juridicidade acima de tudo quanto se conhece", nas palavras de Paulo Bonavides ${ }^{68}$.

O mesmo autor continua no mesmo sentido:

\footnotetext{
${ }^{66}$ SILVA, José Afonso da. Op. cit. p. 622.

${ }^{67}$ FIORILLO, Celso Antonio Pacheco. Op. cit. p. 133.

${ }^{68}$ BONAVIDES, Paulo. Op. cit., p. 344.
} 
"Não conhecemos uma única forma de união federativa contemporânea onde o princípio da autonomia municipal tenha alcançado grau de caracterização política e jurídica tão alto e expressivo quanto aquele que consta da definição constitucional do novo modelo implantado no País com a Carta de 1988", ${ }^{69}$

Por isso, comum é a afirmação de que houve o ressurgimento do municipalismo, com o fortalecimento da importância do Município frente aos demais entes federados. Isto porque, pela primeira vez, o Município foi colocado ao lado dos Estados e da União na Federação brasileira, distanciando-se das entidades locais dos demais países, haja vista que no protótipo federativo mundial o Município não entra na composição da Federação $^{70}$.

Esse tratamento diferenciado que a Constituição conferiu ao ente local é bem sintetizado por Fiorillo: "O Município, adotado como ente federativo, conforme preceituam os arts. $1^{\circ}$ e 18 da CF, recebeu autonomia, possuindo competências exclusivas (art. 30) e organização política própria (art. 29)" 71.

As competências previstas no artigo 30 serão melhor analisadas nos próximos subcapítulos e, com relação ao mencionado artigo 29, cumpre destacar a lição de Paulo Bonavides, segundo o qual referido artigo garante:

"um considerável acréscimo de institucionalização, em apoio à concretude do novo modelo federativo estabelecido pelo art. 18, visto que determina seja o município regido por lei orgânica, votada por quorum qualificado de dois terços dos membros da Câmara Municipal requisito formal que faz daquele estatuto um diploma dotado de grau de rigidez análogo ao que possuem as cartas constitucionais" ${ }^{\text {,72 }}$.

Importante salientar, todavia, que ainda há um déficit na autonomia dos Municípios em decorrência do processo histórico brasileiro. Além disso, Fernando Dias Menezes de Almeida $^{73}$ entende que a disposição do Município como ente da Federação "é uma verdadeira armadilha em relação à sua autonomia real", haja vista que

\footnotetext{
${ }^{69}$ BONAVIDES, Paulo. Op. cit. p. 347.

${ }^{70}$ CASTRO, José Nilo de. Direito Municipal Positivo. Belo Horizonte: Editora del Rey. 2006, p. 18.

${ }^{71}$ FIORILLO, Celso Antonio Pacheco. Op. Cit. p. 132.

72 BONAVIDES, Paulo. Op. cit., p. 345.

73 ALMEIDA, Fernando Dias Menezes, Crítica ao tratamento constitucional do município como ente da federação brasileira. Revista de Direito Constitucional e Internacional, vol. 68, Julho 2009, p. 81
} 
devem seguir o "modelo de estruturação estatal federal e estadual, notadamente no aspecto de governo".

Assim, o autor conclui que a Constituição deveria ter imposto parâmetros de descentralização, para que os "Municípios possam estruturar-se segundo modelos mais variados e adaptados à realidade nacional, garantidas suas competências legislativas e materiais"

Com a ressalva de referido engessamento estrutural, ao menos no plano do dever-ser a Constituição buscou atender ao anseio de maior autonomia dos Municípios. Até mesmo porque, conforme bem recorda referido autor, "os Municípios são o espaço da vida política dos indivíduos, do que diz respeito à sua convivência cívica, voltada ao seu bem estar, no plano individual e no plano coletivo"75.

Verificada a força do Município estampada no pacto federativo, não parece estranho que tal ente passe a buscar soluções a conflitos locais sem necessariamente seguir os entes superiores, notadamente quando se tratar de questões que envolvem a qualidade do meio ambiente e a saúde dos munícipes.

Em suma, pode-se concluir que a Constituição Cidadã de 1988 deu um grande passo para o reconhecimento da autonomia conferida ao ente municipal, estabelecendo um pacto federativo mais condizente com a democracia.

Ao conferir importante autonomia para o ente municipal, pode-se vislumbrar um mandamento constitucional que acaba por refletir em todo o ordenamento jurídico, ampliando as possibilidades de ações localizadas em prol de uma política municipal protetiva do meio ambiente.

\subsection{A competência material do Município a respeito do meio} ambiente

Os Municípios são entes federativos dotados de autonomia própria, materializada por sua capacidade de autolegislação, auto-organização, autogoverno e autoadministração.

\footnotetext{
${ }^{74}$ ALMEIDA, Fernando Dias Menezes. Op. Cit. p. 82.
}

${ }^{75}$ ALMEIDA, Fernando Dias Menezes. Op. Cit., p. 80. 
Com relação à competência material dos Municípios na seara ambiental, foi determinada constitucionalmente a incumbência do ente local "proteger o meio ambiente e combater a poluição em qualquer de suas formas", conforme artigo 23, inciso VI, da Constituição Federal. O dispositivo constitucional, buscando assegurar a maior proteção possível ao meio ambiente ecologicamente equilibrado, houve por bem incluí-lo na esfera de competência comum, de modo que todos os entes federativos receberam referido poder-dever constitucional.

Conforme leciona Hely Lopes Meirelles:

"se o município tem o poder de agir em determinado setor para amparar, regulamentar ou impedir uma atividade útil ou nociva à coletividade, tem, correlatamente, o dever de agir, como pessoa administrativa que é, armada de autoridade pública e de poderes próprios para a realização de seus fins" 76 .

Em que pesem as possibilidades que foram conferidas ao Município, Gilda Collet Bruna critica a atual posição da maioria deles em suas incumbências, especialmente na seara ambiental: "Poucos municípios têm seu Plano Diretor atualizado e raramente se utilizam deste plano para direcionar o seu uso e ocupação do território, estimulando, simultaneamente, o controle e a proteção ambiental" 77.

Dessa forma, caso não seja fortalecida a autonomia real dos entes municipais, e, consequentemente, não havendo atuação mais concreta dos Municípios, pode-se vislumbrar, por exemplo, um agravamento dos problemas relacionados à ocupação desordenada das cidades. Isto porque, diante do tradicional aviltamento municipal, acostumou-se o ente local com um "laissez-faire", como se a cidade pudesse se ordenar sem um plano municipal adequado.

Todavia, não se pode mais permitir que as atividades econômicas ou mesmo a ocupação das áreas urbanas, se dêem à revelia de planos municipais de desenvolvimento urbano, haja vista que estes devem ser feitos nos termos da ordem urbanística implantada. Esta, segundo a doutrina de Paulo Affonso Leme Machado, "é o conjunto de normas de ordem pública e de interesse social que regulam o uso da

\footnotetext{
${ }^{76}$ MEIRELLES, Hely Lopes. Op. cit. p. 135.

77 BRUNA, Gilda Collet. Meio Ambiente urbano e proteção ambiental. In: Alaôr Caffé Alves; Arlindo Philippi Jr; Marcelo de Andrade Roméro; Gilda Collet Bruna. (Org.). Meio Ambiente, Direito e Cidadania. $1^{\mathrm{a}}$ ed. São Paulo: SIGNUS / NISAM-USP, v.1, 2002, p.25.
} 
propriedade urbana em prol do bem coletivo, da segurança, do equilíbrio ambiental e do bem-estar dos cidadãos (...) deve significar a institucionalização do justo na cidade" ${ }^{78}$.

No entanto, referida tarefa não é fácil. Como recorda Gilda Collet Bruna, as mudanças sempre exigem esforços da sociedade, sem contar que se o plano diretor for muito restritivo, poderá "engessar a dinâmica urbana e apressar a fuga, do município, de atividades que não se adaptam a essas restrições"79. Além disso, é sabido que muitos Municípios e Estados fazem muitas concessões para receber empresas em seus territórios, sendo que, se não lhes fosse vedado, muitos acabariam por abrandar as normas ambientais e urbanísticas de uso e ocupação do solo para atraí-las.

Daí a importância das normas ambientais e urbanísticas não poderem ser mais brandas que aquelas fixadas pelas normas gerais da União e dos Estados, as quais criam um patamar mínimo de proteção. Na lição de Motauri Ciocchetti de Souza, a União edita as normas gerais com os patamares básicos de proteção e, não obstante, "Estados e Municípios podem sempre instituir padrões mais rigorosos de qualidade ambiental, ampliando, destarte, os limites instituídos pela lei federal" ${ }^{100}$.

Assim, com a Constituição de 1988 o Município ganhou relevância ímpar quando passou a ser responsável pela política de desenvolvimento urbano. De acordo com o artigo 182 da Carta Magna, esta "tem por objetivo ordenar o pleno desenvolvimento das funções sociais da cidade e garantir o bem-estar de seus habitantes".

Dentre as formas do poder público municipal exercer sua competência administrativa na tutela do meio ambiente, destaca-se a ordenação da cidade por meio de um bem planejado Plano Diretor, que é instrumento básico da política de desenvolvimento e expansão urbana. E para dar cumprimento às exigências fundamentais deste plano - entre as quais se destaca a função social da propriedade urbana e rural vislumbra-se a utilização indispensável do exercício de poder de polícia, com a fiscalização das atividades e aplicando, se necessário, as penalidades que se mostrarem necessárias.

Entretanto, caso verifique-se omissão do ente local, ou pior, se num determinado caso concreto os interesses econômicos e políticos do Poder Executivo

\footnotetext{
${ }^{78}$ MACHADO, Paulo Affonso Leme. Op. Cit. p. 392.

${ }^{79}$ BRUNA, Gilda Collet. Op. Cit. p. 28

${ }^{80}$ SOUZA, Motauri Ciocchetti de. Interesses Difusos em Espécie. $2^{\circ}$ Ed. São Paulo: Saraiva, 2009, p. 82.
} 
Municipal sobrepujarem a proteção do equilíbrio ecológico local, mister se faz a atuação da sociedade para coibir referidas condutas abusivas, sejam elas comissivas ou omissivas.

Conforme leciona Paulo Affonso Leme Machado:

"Hoje não se discute a necessidade de as pessoas e organizações não governamentais participarem dos procedimentos de tomada de decisão no que diz respeito ao meio ambiente. Os canais antigos de representação e a forma de exercício da atividade da Administração Pública, inclusive municipal, revelaram-se destituídos de eficácia" ${ }^{81}$.

Como é sabido, a maior proximidade entre o bem a ser tutelado e a população confere um controle mais amplo e eficaz ao meio ambiente local. $\mathrm{O}$ conhecimento dos problemas ambientais e das mazelas locais pode ser bastante positivo na atuação em favor da proteção ambiental.

Nesse sentido, a comunidade deve buscar ficar atenta para detectar os problemas que afetem sua localidade, ao mesmo tempo em que devem ser buscadas as correspondentes soluções. Como exemplo corriqueiro de necessidade de melhora da ordem urbanística paulistana, Paulo Affonso Leme Machado menciona que "o nível de emissão sonora precisa ser adequado e o transporte individual e público deve ser transformado, evitando-se a poluição e o estresse dos engarrafamentos" ${ }^{82}$.

Diante de todo esse contexto, para o poder público municipal exercer o comando constitucional que lhe foi incumbido de forma desejável, imperiosa se faz a possibilidade de edição de normas a respeito de tais matérias.

De acordo com a doutrina de Paulo de Bessa Antunes ${ }^{83}$, "seria incorreto e insensato dizer-se que os Municípios não têm competência legislativa em matéria ambiental, visto que teriam que abrir mão de sua autonomia constitucional para cumprir os próprios mandamentos constitucionais." Assim, conclui referido autor que "o meio ambiente está incluído dentre o conjunto de atribuições legislativas e administrativas municipais e, em realidade, os Municípios formam um elo fundamental na complexa cadeia de proteção ambiental”.

Como já visto, se a Constituição Federal conferiu uma finalidade específica ao órgão municipal, certamente está lhe atribuindo conjuntamente os meios

\footnotetext{
${ }^{81}$ MACHADO, Paulo Affonso Leme. Op. Cit. p. 391.

${ }^{82}$ MACHADO, Paulo Affonso Leme. Op. Cit. p. 393.

${ }^{83}$ ANTUNES, Paulo de Bessa. Ob. Cit. p. 112
} 
necessários para a consecução desta finalidade. Assim, a obrigação de cuidar do meio ambiente traz em si a possibilidade da produção de leis para exercer adequadamente este cuidado.

Nesse sentido também é o ensinamento de Édis Milaré, ao afirmar que "se a Constituição conferiu-lhe poder para proteger o meio ambiente e combater a poluição em qualquer de suas formas (art. 23, VI) - competência administrativa -, é óbvio que, para cumprir tal missão, há que poder legislar sobre a matéria" ${ }^{84}$.

Em suma, diante da competência material de proteger o meio ambiente e combater a poluição em qualquer de suas formas que fora atribuída ao ente municipal, é defendido que, para que o Município possa exercer tal comando constitucional a contento, imperiosa se faz a possibilidade de normatização de tais matérias pelo ente municipal. Assim, passa-se doravante ao estudo de referida competência legislativa municipal.

\subsection{A competência legislativa do Município}

Neste subcapítulo será tratado, de maneira mais específica, a análise da competência do Município para legislar sobre meio ambiente. Discute-se a respeito da possibilidade do ente municipal editar leis ambientais porque a competência para legislar sobre meio ambiente está expressa tão somente no artigo 24 da Carta Magna, que se refere à competência concorrente da União, Estados e Distrito Federal, havendo omissão quanto ao Município.

Como bem recorda Édis Milaré ${ }^{85}$, a falta do Município na competência legislativa concorrente do artigo 24 levaria "muitos à conclusão precipitada de que ele não teria competência normativa na matéria”. No entanto, o autor complementa demonstrando que "Levado ao pé da letra tal entendimento, chegar-se-ia ao absurdo de sustentar também que ele não tem competência para legislar sobre urbanismo, por ser matéria de competência concorrente incluído no art. 24. É evidente o disparate!”.

\footnotetext{
${ }^{84}$ MILARÉ, Édis. Direito do Ambiente. Revista dos Tribunais: 2009. $6^{\text {a }}$ edição. p. 191

${ }^{85}$ MILARÉ, Édis. Op. Cit. 191.
} 
Por isso, além da análise realizada a respeito da competência concorrente, de suma relevância será extrair o conteúdo ambiental das competências legislativas municipais expressas no artigo 30 da Constituição Federal. In verbis: “Art. 30 Compete aos Municípios: I - legislar sobre assuntos de interesse local; II- suplementar a legislação federal e estadual no que couber".

Assim, apesar de não haver poderes expressos para os Municípios produzirem normas sobre meio ambiente no artigo 24, pode-se chegar a elas por hermenêutica jurídica do artigo 30, incisos I e II, da Constituição Federal. Conforme leciona Paulo Bonavides, "o art. 30, discriminando a matéria de competência dos municípios, tem uma latitude de reconhecimento constitucional desconhecida aos textos antecedentes de nosso constitucionalismo" ${ }^{86}$.

Assim, haverá exclusividade do Município para as normas de interesse local, bem como a possibilidade de exercício de sua competência legislativa suplementar. De maneira sintética, o interesse local diz respeito às peculiaridades e necessidades ínsitas à determinada localidade, enquanto a suplementação "no que couber" baliza a atuação municipal dentro do interesse local.

Fernanda Menezes ainda fortalece as competências Municipais, ao asseverar que "em lugar da enumeração exaustiva e pormenorizada das competências dos Municípios, preferimos optar por uma formulação sintética, não, porém, menos abrangente, partindo do princípio geral de Direito, segundo o qual 'o que não for proibido é permitido" 87 .

\subsubsection{O interesse local}

Com relação ao primeiro inciso do artigo 30 da Constituição da república, deve-se buscar entender exatamente o que seriam tais "assuntos de interesse local” para se poder alcançar a real extensão de seu significado na seara ambiental.

Até o advento da Constituição Federal vigente, utilizava-se a expressão "peculiar interesse" do Município, ao passo que a Carta Magna substituiu-a por “interesse local”. Conforme observa Hely Lopes, referida mudança "ganhou em amplitude

${ }^{86}$ BONAVIDES, Paulo. Op. cit., p. 346.

${ }^{87}$ ALMEIDA, Fernanda Dias Menezes de. Op. Cit. p. 53. 
e precisão conceitual, permitindo a evolução e adaptação do regime estabelecido, em face da vastidão do território nacional e das particularidades de cada localidade" ${ }^{88}$.

Ainda assim, de modo geral não é tarefa fácil a definição do que seria um interesse meramente local. Pode-se pensar, de um lado, que a Constituição teria restringido a competência municipal, outorgando-lhes tão somente os interesses que fossem exclusivos deste, enquanto os assuntos que também resvalassem na esfera dos demais entes ficassem tão somente a cargo desses.

Referida visão não parece ser a mais correta. A interpretação sistemática da Constituição Cidadã parece estar em sintonia com a ideia de que interesse local seria aquele que está relacionado de forma imediata aos anseios municipais, ainda que refletisse nas necessidades dos Estados ou da União. Nesse sentido, Paulo Affonso Leme Machado assevera que "o interesse local não se caracteriza pela exclusividade do interesse, mas pela sua predominância" 89 .

Corroborando tal entendimento, de maneira ainda mais incisiva, Hely Lopes afirma que:

\footnotetext{
"Interesse Local não é interesse exclusivo do Município; não é interesse privativo da localidade; não é interesse único dos munícipes. Se se exigisse essa exclusividade, essa privatividade, essa unicidade, bem reduzido ficaria o âmbito da Administração local. O interesse local é a predominância do interesse do Município sobre o do Estado ou da União." 90
}

Referida predominância do interesse local se mostra mais condizente com o ideal municipalista da Constituição Federal do que a exigência de exclusividade desse interesse, até porque os assuntos tratados pelo ente municipal sempre atingem, ainda que reflexamente, os interesses dos entes superiores.

Assim, para a compreensão do que seriam os interesses locais, o primeiro critério a ser utilizado será a verificação da predominância dos interesses municipais quando em comparação com os Estados e União. Desse modo, surgirá a competência municipal quando houver interesses locais que lhes são próprios, peculiares

\footnotetext{
${ }^{88}$ MEIRELLES, Hely Lopes. Op. Cit. p. 134.

${ }^{89}$ MACHADO, Paulo Affonso Leme. Op. Cit. p. 389.

${ }^{90}$ MEIRELLES, Hely Lopes. Op. Cit. p. 109/110.
} 
deste ente, ainda que não abarquem todo o Município, bastando que haja interesse de parte dele, a exemplo de uma atividade relacionada a um bairro específico.

Por isso, Paulo Affonso Leme Machado leciona que:

"O "interesse local" não precisa incidir ou compreender, necessariamente, todo o território do Município, mas uma localidade, ou várias localidades, de que se compõe um Município. Foi feliz a expressão usada pela Constituição Federal de 1988. Portanto, pode ser objeto de legislação municipal aquilo que seja da conveniência de um quarteirão, de um bairro, de um subdistrito ou de um distrito.“"

Outra alternativa para tentar melhor enquadrar tais interesses locais seria a utilização do método negativo, isto é, verificar aqueles assuntos que, por sua natureza, transpassam o âmbito do Município. Como exemplo, temos as telecomunicações, a informática, o serviço postal, o sistema estatístico, entre outros. Retirados estes, poderia ficar mais fácil pensar nos assuntos de interesse local, como aqueles que não sejam de âmbito nacional ou regional, sobrando somente aqueles que direta e imediatamente afetem a comunidade.

Em Ações Diretas de Inconstitucionalidades e similares, o Supremo Tribunal Federal entendeu que competiria ao Município legislar sobre diversos assuntos considerados locais. A título exemplificativo pode-se citar: i) direito à meia passagem aos estudantes, nos transportes coletivos municipais; ii) medidas de conforto e segurança aos usuários de bancos, como fornecimento de cadeiras de espera e bebedouros, bem como instalação de portas eletrônicas e câmaras filmadoras; iii) limite de tempo de esfera em fila dos cartórios localizados no seu respectivo território; e iv) horário de funcionamento do comércio local, como o das farmácias ${ }^{92}$.

Com relação ao último assunto, se não bastassem as decisões reiteradas no sentido da competência municipal, o Supremo Tribunal Federal houve por bem editar a Súmula n. 645, a qual prevê que: “é competente o Município para fixar o horário de funcionamento de estabelecimento comercial."

Como se vê, a dicção constitucional preferiu não elencar o rol de matérias locais, de modo que agiu corretamente o legislador constituinte, haja vista que as

\footnotetext{
${ }^{91}$ MACHADO, Paulo Affonso Leme. Op. Cit. p. 389.

${ }^{92}$ LENZA, Pedro. Direito constitucional esquematizado. 16a edição.São Paulo: Saraiva. 2012, p. 459/462.
} 
mutações da vida moderna poderiam tornar obsoleta a catalogação. Assim, de maneira sintética pode-se dizer que o interesse local é aquele que direta e imediatamente atinge a comunidade que vive o problema a solucionar.

De modo sintético, Fiorillo ${ }^{93}$ explica a questão:

“Ao atribuir ao Município competência para legislar sobre assuntos locais, está-se referindo aos interesses que atendem de modo imediato às necessidades locais, ainda que tenham repercussão sobre as necessidades gerais do Estado ou do País. Com isso, questões como o fornecimento domiciliar de água potável, o serviço de coleta de lixo, o trânsito de veículos e outros temas típicos do meio ambiente natural, artificial, cultural e do trabalho no âmbito do Município, embora de interesse local, não deixam de afetar o Estado e mesmo o país".

A controvérsia maior parece estar relacionada a estas questões que envolvem interesses locais, regionais e até nacionais simultaneamente. Em tais casos, nos quais a defesa do meio ambiente certamente se insere, fica difícil de se estabelecer qual o interesse que deveria predominar.

Um questionamento que poderia se mostrar pertinente seria, na concomitância de lei federal, estadual e municipal, qual das normas deveria ser aplicada. Pode-se pensar em solucionar a questão aplicando-se a legislação mais rigorosa ambientalmente, na medida em que ao se observar esta, implicitamente se estaria cumprindo também as demais.

Um exemplo prático no qual há normas que se somam se dá nas regiões metropolitanas. Especificamente em São Paulo, muitas são as normas que se referem à proteção dos mananciais que abastecem a região metropolitana, havendo normas do Estado de São Paulo, que não excluem as disposições dos Municípios que a integram. Em tais casos, pode-se falar em competência concorrente cumulativa.

Segundo Alaor Caffé Alves:

"[havendo] discrepância entre tais dispositivos, prevalece a prescrição mais restritiva, não em razão da hierarquia das leis, que na hipótese vertente não existe, mas sim de sua eficácia, tendo em vista que o

\footnotetext{
${ }^{93}$ FIORILLO, Celso Antonio Pacheco. Op. cit. p. 133.
} 
administrado está sob o influxo de duas ordens jurídicas autônomas, devendo subordinar-se a ambas" ${ }^{94}$.

Desse modo, deve-se buscar a aplicação tanto das normas federais e estaduais quanto das municipais, e, uma vez observada a legislação mais rigorosa, automaticamente estar-se-á aplicando os demais comandos normativos. Em razão disso, critica-se o uso exclusivo do critério da predominância do interesse para embasar a repartição das competências constitucionais. Justamente por ele não resolver os problemas da distribuição de competências em matérias complexas, como a ambiental, passou-se a reivindicar sua aplicação em conjunto com o princípio da subsidiariedade, possibilitando a inserção da lei municipal no ordenamento jurídico.

Até mesmo porque a possibilidade do Município editar leis e atos normativos mais restritivos para bem equalizar os problemas de ordem local parece se tratar de uma incumbência constitucional que veio para homenagear o princípio da democracia, da participação popular e, sobretudo, da cidadania.

Nesse sentido é a lição de Fiorillo:

"Isso possibilita uma tutela mais efetiva da sadia qualidade de vida, porquanto é no Município que nascemos, trabalhamos, nos relacionamos, ou seja, é nele que efetivamente vivemos. Na verdade, é o Município que passa a reunir efetivas condições de atender de modo imediato às necessidades locais, em especial e um país como o Brasil, de proporções continentais e cultura diversificada" ${ }^{95}$.

Continuando o raciocínio, ao autor lembra que:

"É no Município que a pessoa humana se educa, cuida de sua saúde, trabalha, se diverte, convive com fatores de segurança/insegurança; é ainda no Município que restarão evidenciados os permanentes conflitos do capital em face do trabalho dentro de ambientes artificiais frequentemente poluídos" ${ }^{96}$.

Diante disso pode-se vislumbrar também que há "assuntos que, embora sejam gerais, apresentam características locais significativas e que demandam uma

\footnotetext{
94 ALVES, Allaor Café, Planejamento Metropolitano e Autonomia Municipal no Direito Brasileiro, São Paulo, Bushatsky, 1981, p. 244. apud ALMEIDA, Fernanda Dias Menezes de. Op. Cit. p. 122/123.

${ }^{95}$ FIORILLO, Celso Antonio Pacheco. Op. Cit. p. 132/133.

${ }^{96}$ FIORILLO, Celso Antonio Pacheco. Op. Cit. p. 133.
} 
regulamentação própria e particular"97, nos dizeres de Paulo de Bessa Antunes. Assim é que, segundo Hely Lopes Meirelles, "os assuntos de interesse local surgem em todos os campos em que o Município atue com competência explícita ou implícita" 98 .

A expressão "interesse local” não garante um núcleo determinado de competências em favor do ente local, dada a própria indeterminação daquele conceito. No entanto, há interesse local em tudo o que direta e imediatamente atingir a comunidade que vive o problema. Em matéria ambiental, embora a preservação ambiental seja ao mesmo tempo do interesse de cada um dos indivíduos e também eminentemente abrangente, o Município tem interesse local porque atua na defesa da qualidade dos bens ambientais de seu território e da qualidade de vida de seus munícipes.

No mais, cumpre citar a lição de Paulo Affonso Leme Machado de que "a noção de interesse local não é unívoca. Haverá interesses locais em choque e, muitas vezes, encontraremos o interesse local pelo desenvolvimento econômico não sustentado ou imediatista, em antagonismo com o interesse local, pela conservação do meio ambiente" 99 .

\subsubsection{A suplementação de lei federal}

Após a análise da questão do interesse local, passa-se ao estudo do inciso II do artigo 30 da Constituição, referente à suplementação da legislação federal e estadual no que couber.

Embora a Constituição Federal não atribua expressamente ao Município a competência legislativa concorrente no artigo 24, por força do artigo 30, inciso II, está o ente menor legitimado constitucionalmente a fazê-lo, nos assuntos que lhe dizem respeito. Assim, haverá competência suplementar do ente municipal com o fim de melhor detalhar princípios ou normas gerais, ou até mesmo para suprir omissão de leis federais e estaduais.

Nesse sentido, restaria ao Município detalhar para regionalizar as normas às suas peculiaridades, desde que haja interesse local. Haverá possibilidade para

\footnotetext{
${ }^{97}$ ANTUNES, Paulo de Bessa. Ob. Cit. p. 175.

${ }^{98}$ MEIRELLES, Hely Lopes. Op. Cit. p. 136.

${ }^{99}$ MACHADO, Paulo Affonso Leme. Op. Cit. p. 389.
} 
suprir as normas estaduais e federais em caso de haver um espaço normativo, a exemplo de quando puder estabelecer normas mais condizentes com a realidade ambiental local.

Pode-se dizer, assim, que ao invés do Constituinte restringir a competência suplementar dos Municípios ao rol exaustivo do artigo 24, preferiu dar uma autorização para que legislem sobre qualquer assunto de interesse predominantemente local.

A lição de José Afonso da Silva corrobora referido entendimento:

“A Constituição não situou os Municípios na área de competência concorrente do art. 24, mas lhes outorgou competência para suplementar a legislação federal e estadual no que couber, o que vale possibilitar-lhes disporem especialmente sobre as matérias ali arroladas e aquelas a respeito das quais e reconheceu à União apenas a normatividade geral." 100

Complementando referida ideia, Fernanda Dias Menezes de Almeida assevera que "a Constituição não define os casos e as regras de atuação da competência suplementar do Município, que surge delimitada implicitamente pela cláusula genérica do interesse local" 101 .

Referida autora ainda sugere que os Estados e Municípios poderiam suplementar para estabelecer como "obrigatória a observância de determinadas cautelas e providências na comercialização do produto" ${ }^{102}$, mas não poderiam vedá-la quando a União tivesse liberado o produto.

Já para Jusara Aparecida Bratz ${ }^{103}$, o termo "suplementar" não poderia mais "ser visualizada como secundária, inferior, ou menos importante". Precisaria ser dada uma interpretação conforme, de modo que "a União e o Estado não podem deixar o município em posição inferior para exercer sua autonomia nas atividades ligadas ao meio ambiente, assim como não podem minimizar ou mesmo esvaziar a competência do município para legislar sobre matéria de direito ambiental”.

No capítulo seguinte serão mais bem analisados alguns exemplos de casos concretos a respeito de proibições locais em contraposição às normas gerais

${ }^{100}$ SILVA, José Afonso da. Op. Cit. p. 504.

${ }^{101}$ ALMEIDA, Fernanda Dias Menezes de. Op. Cit. p. 139.

102 ALMEIDA, Fernanda Dias Menezes de. Op. Cit. p. 142.

103 BRATZ, Jusara Aparecida. Competência do município para legislar em matéria ambiental à luz do princípio da subsidiariedade. Belo Horizonte: Revista interesse público, $\mathrm{n}^{\circ}$ 67, ano XIII, maio/junho 2011, p. 269/272. 
permissivas, de forma que se ficará mais fácil visualizar inúmeras possibilidades de conflitos que podem se instaurar entre as legislações ambientais de diferentes entes federados.

Por enquanto, cumpre verificar que pela leitura do inciso II do artigo 30 é possível vislumbrar a imposição de certas limitações ao poder legislativo municipal. Referidos limites parecem estar evidentes na expressão "no que couber" do referido inciso. Diante da literalidade da norma constitucional, grande parte da doutrina defende que os Municípios só poderiam criar leis ambientais que não contrariassem os parâmetros fixados pela União ou Estados ${ }^{104}$.

O Município, assim, teria competência legislativa concorrente, suplementar, de modo que suas normas deveriam estar de acordo com os regramentos estaduais e federais, não sendo possível legislar de modo contrário a essas normas. Nesse viés, a competência municipal estaria subordinada às normas estaduais e federais. $\mathrm{O}$ Município, ao dispor sobre essas matérias em razão de seu interesse local, não poderia ir contra o que se estabeleceu em âmbito federal e estadual, apesar de que seu interesse não fica restrito ao que tais entes estabeleceram.

Fernanda Dias Menezes assevera que seria preciso verificar quando seria cabível a legislação municipal, já se manifestando por só ser possível a "suplementação em relação a assuntos que digam respeito ao interesse local"105.

Nesse sentido, as normas ambientais Municipais deveriam estar em consonância com as da União e do Estado, não podendo dispor de forma contrária a estes. Por isso, muito se fala na existência de uma verdadeira "fidelidade federal/estadual" com relação a tais normas dos Municípios.

Diante disso, primeiramente pode-se pensar uma competência suplementar dos Municípios, sendo exercida sempre em concordância com as normas gerais da União e com as normas estaduais correspondentes. Essa correlação busca evitar que o território nacional se transforme num conjunto de ilhas, perdendo a unidade da Nação e possibilitando que interesses protecionistas criem barreiras comerciais indesejáveis.

${ }^{104}$ MILARÉ, Édis. Op. Cit. p. 192.

105 ALMEIDA, Fernanda Dias Menezes de. Op. Cit. p. 139. 
De outro lado, é aceito que os Municípios podem aumentar as restrições impostas na legislação federal e estadual para assegurar maior proteção ambiental em seu território, com vistas a defender melhor as particularidades ambientais de seu local.

O cerne da discórdia, desse modo, está relacionado à possibilidade da suplementação da norma federal e estadual ser tão restritiva que acabaria por contrariar as normas gerais fixadas.

Todavia, sabendo da importância de regras ambientais mais protetivas em certas localidades específicas, bem como de que seria impossível à normatização geral da União alcançar tais "detalhes" nacionalmente considerados, não se pode extirpar sumariamente do ordenamento as leis locais, antes de se fazer uma análise do mérito das mesmas.

Isto porque, embora possa existir legislação mal intencionada, visando, por exemplo, proteger os mercados locais de certos produtos ou atividades comerciais, isso não pode servir de escusa para se execrar todas as legislações municipais ambientalmente mais restritivas.

Por isso, tentar-se-á demonstrar que ao invés de privilegiar "de olhos vendados" a norma Federal ou Estadual em matéria ambiental, poder-se-ia pensar na resolução de um conflito de normas com a prevalência da lei que for mais benéfica em relação à natureza, desde que esta tenha levado em consideração as preocupações acima discutidas.

Além disso, quando uma lei municipal e outra estadual/federal divergirem a respeito da proteção do meio ambiente, muito provavelmente estar-se-á diante de um caso concreto no qual ainda há dúvidas sobre a possibilidade ou não da atividade ou produto serem danosos ao ambiente. Nesse caso, parece prudente a aplicação do princípio da precaução, que é utilizado justamente nas situações em que a lesividade ambiental de algo não está pacificada pela ciência.

Aplicando tal solução, busca-se impedir que o dano ambiental ocorra, ainda que haja somente um risco, uma possibilidade de tal dano. Nesse viés, a utilização da legislação ambiental mais restritiva parece que melhor se coaduna com a hermenêutica do direito ambiental. Nesse sentido, inclusive, é a Lei federal $n^{\circ} 7.661 / 88$, 
que estabelece expressamente no $\S 2^{\circ}$ do artigo $5^{\circ}$ a prevalência das disposições de natureza mais restritiva dos Estados e Municípios.

Em suma, pode-se vislumbrar que somente a implementação de uma verdadeira política ambiental municipalizada poderá alcançar a tutela efetiva da qualidade ambiental e, consequentemente, da saúde pública. Estando mais próximo dos munícipes, o poder local teria também uma maior facilidade na compreensão da problemática ambiental de seu território, de modo que suas leis podem acarretar uma melhora do ambiente, de maneira mais eficaz.

Portanto, na competência para suplementar a legislação federal e a estadual, competirá aos Municípios, especialmente, legislar supletivamente sobre o meio ambiente, assegurando maior proteção.

\subsection{Os limites materiais da legislação ambiental dos}

\section{Municípios}

Passada a análise das competências do ente Municipal para a edição de leis ambientais, importante se faz ressaltar que sua atuação não poderia exceder algumas limitações, sob pena de haver uma inconstitucionalidade material de referidas normas.

Isso porque, em que pese o objeto central do presente estudo esteja relacionado às regras de distribuições de competências formais entre os entes federativos estabelecidas pela Constituição Federal de 1988, parece importante também fazer breves comentários sobre o conteúdo material das leis editadas pelos Municípios, com vistas a perquirir eventual inconstitucionalidade material.

Isso se dá, especialmente, porque se tem mostrado extremamente complexa a análise separada das eventuais inconstitucionalidades formais ou materiais dessas leis que buscam proteger o meio local. Conforme será mais bem verificado no capítulo seguinte (a respeito das ações de inconstitucionalidade contra leis municipais concretas), em praticamente todos os julgamentos, para enfrentar a competência do Município para a edição de norma ambiental, os Desembargadores ou Ministros justificam sua posição com base no conteúdo material da norma. 
Assim, tanto para os que julgam as leis constitucionais, como para os que declaram a inconstitucionalidade, praticamente nunca o fazem a partir de uma análise meramente teórica. Pelo contrário, a argumentação sobre a (in)constitucionalidade da lei municipal sobre temas ambientais sempre é feita a partir do conteúdo material da norma.

Nesse sentido, inclusive, é o posicionamento de Paulo de Bessa Antunes:

"A realidade do mundo moderno não permite mais que uma Corte Constitucional - como de resto qualquer órgão do Poder Judiciário -, ao decidir uma questão que lhe é submetida, limite-se ao exame do preenchimento de uma formalidade legal, olvidando-se do conteúdo concreto da decisão proferida e de suas repercussões no mundo fenomenológico. Aliás, há que se sublinhar que forma e conteúdo mantêm entre si uma relação dialética de complementaridade e, evidentemente, uma não existe sem a outra"106.

Por isso, não se pode deixar de levar em consideração as repercussões de ordem econômica que a eventual restrição ou proibição trazida com a lei municipal mais protetiva irá trazer. Como é sabido, as leis não poderão simplesmente aniquilar uma atividade econômica, pelo contrário, devem almejar um desenvolvimento sustentável com vistas a conciliar a proteção ambiental com o desenvolvimento econômico.

O Município, por ser o ente mais próximo da população, acaba por conhecer melhor o nível de proteção da saúde e do meio ambiente que seus munícipes desejam. No entanto, não se pode admitir que cada Município faça o que entender melhor, proibindo mercadorias ou atividades indiscriminadamente e sem justificativas concretas. Até porque, a depender das consequiências práticas que os munícipes possam sofrer com as leis que trazem restrições ambientais, será permitida a declaração de inconstitucionalidade de referida norma.

Diante disso, se mostra fundamental analisar os limites materiais que as leis municipais ambientais devem obedecer. Em que pese ser possível a edição de leis pelo ente local trazendo maior proteção ao meio ambiente, elas só poderão ser feitas se não trouxerem externalidades negativas piores do que as causadas pelos danos ambientais.

${ }^{106}$ ANTUNES, Paulo de Bessa. Op. cit. p. 307 
Além disso, para fazer uma proibição, o Município deve ter uma política coerente de proteção da saúde da população e do meio ambiente. Não poderia, por exemplo, proibir a queima da palha da cana-de-açúcar e, ao mesmo tempo, aceitar a instalação de atividades que causem maiores danos à qualidade ambiental do local.

Antes de se proibir a circulação de um produto ou a realização de uma atividade, inúmeros fatores devem ser considerados. Primeiro está a coerência do Município, conforme já mencionado. Outro fator seria a realização de estudos que comprovassem, pelo menos potencialmente, a nocividade do produto ou atividade. E tais estudos deveriam ser sempre atualizados, buscando comprovar que aquela atitude tomada pelo Município realmente trouxe benefícios aos munícipes.

Por isso, mister se faz uma análise específica de cada situação singular e, a partir dela, pode-se verificar a possibilidade da edição de leis que representem uma conciliação concreta entre o desenvolvimento econômico e a proteção ambiental.

No primeiro caso concreto que será tratado no capítulo seguinte, a respeito da proibição da queima da palha da cana-de-açúcar, será visto que os Desembargadores sempre utilizam como argumento, como ponto fulcral do debate acerca da (in)constitucionalidade da lei, as conseqüência nas relações sócio-econômicas para o Município.

Os que entendem que o Município não teria competência para editar referida lei afirmam que a proibição da queima implicaria em vultosos investimentos para as empresas do setor, afetando seus lucros. Além disso, afirmam que tal prática aumentaria o desemprego nos locais, bem como que não haveria comprovação científica acerca dos malefícios da queima da cana.

Diante desses argumentos utilizados como exemplo, percebe-se que, mesmo para os Desembargadores que entendem que o Município não teria competência para a edição de leis ambientais mais protetivas, ainda assim eles entendem importante perquirir o conteúdo da norma, verificando a constitucionalidade material da mesma.

Portanto, a análise da (in)constitucionalidade formal e material das leis municipais a respeito do meio ambiente é feita de modo conjunto, com forte ingerência de uma sobre a outra. Em que pese na teoria seja possível fazer uma diferenciação clara entre a constitucionalidade formal e material da norma, na prática essas questões são verificadas conjuntamente. 
E não se trata de falta de conhecimento teórico a respeito dos mecanismos de controle de constitucionalidade por parte dos julgadores, até porque quem decide tais casos são os Desembargadores integrantes do Órgão Especial do Tribunal de Justiça, bem como os Ministros do Supremo Tribunal Federal.

Certamente os integrantes da cúpula do Poder Judiciário conhecem muito bem as espécies de inconstitucionalidades existentes no ordenamento jurídico pátrio. Ocorre que, num determinado caso concreto, a análise formal do processo não se mostra suficiente.

Antes de declarar a inconstitucionalidade da edição de uma lei ambiental por parte de um ente federado, os julgadores buscam sopesar os malefícios ambientais de referida atividade, com o prejuízo econômico e social que advirá de referida restrição ou proibição.

A partir desse pressuposto, o órgão verificador da constitucionalidade das leis deve apurar a viabilidade da extensão da suplementação da lei federal pelo ente municipal em cada caso concreto. Se assim não fosse, como já foi considerado nesta dissertação, a liberdade total e irrestrita acabaria por transformar o País num conjunto de ilhas, sem qualquer unidade nacional.

Certamente existe interesse do Município na edição de leis de proteção do meio ambiente local, assim como da saúde dos munícipes, no entanto, não se pode aceitar a transformação do Brasil em uma somatória de Municípios isolados. Diante disso, não se pode negar a importância de um regramento mínimo e uniforme para as atividades que possam trazer danos ao meio ambiente, pois a diversidade de normas sem qualquer parâmetro poderia mais prejudicar que ajudar o País.

Além desta preocupação geral, também pode ser vislumbrada a imposição de barreiras protecionistas veladas, a exemplo de um Município que vedasse determinado produto somente para promover sua indústria local que utilizaria outro material com a mesma finalidade.

O protecionismo imotivado não é aceito nem mesmo entre os países soberanos, então com mais razão para a proibição entre os Municípios. Em qualquer caso, 
deve haver uma exigência de proporcionalidade para se tomar qualquer medida de restrição ao comércio, sob pena restar configurado discriminação comercial. ${ }^{107}$

Hélène Ruiz-Fabri sugere que, para qualquer restrição de um produto potencialmente perigoso, deveria ser realizado um "teste de necessidade", isto é, deveriam ser sopesados os fatores para: "assegurar, por um lado, que a natureza da medida permita atingir o objetivo procurado - a proteção à saúde; por outro, que o objetivo sanitário perseguido não possa ser atingido por outra medida menos restritiva do comércio"108.

Além de tais casos, outro exemplo interessante citado por Fernanda Dias Menezes Almeida se refere a uma situação real da década de 80 no Brasil. Conforme mencionou a autora, a pretexto da proteção da saúde pública e do meio ambiente, "alguns Estados e Municípios têm proibido a venda de álcool combustível a que adicione metanol, por entenderem a mistura prejudicial à saúde e ao meio ambiente. Isto muito embora a União tenha liberado a venda do produto no território nacional." 109

Diante de tal caso, a autora conclui que: "as sérias dificuldades que a legislação fracionada poderia causar ao deslocamento das pessoas no território nacional, se cada Estado ou Município decidisse que tipos de combustível seriam passíveis ou não de venda no respectivo âmbito territorial." $" 110$

Assim, para mencionada autora, referida proibição não poderia ter sido feita, haja vista que os combustíveis vendidos nos postos de gasolina possuem padrões nacionais. No julgamento da Ação Direta de Inconstitucionalidade n. 12.368-0/1, restou decidido que realmente não se poderia haver intromissão nesta questão ambiental em razão da direta ressonância nacional da matéria, inclusive porque a competência para a expedição da licença relativa à atividade se dá por órgão federal em todo o território do país.

Diante desse caso, percebe-se que as situações concretas precisam de uma análise acurada para saber até onde o Município pode impor suas convicções. Como visto, as preocupações sócio-econômicas certamente devem ser levadas em conta quando da edição de leis pelo ente local. A busca da melhoria da qualidade ambiental deve ser

\footnotetext{
107 VARELLA, Marcelo Dias. Variações sobre um mesmo tema: o exemplo da implementação do princípio da precaução pela CIJ, OMC, CJCE e EUA in VARELLA, Marcelo Dias e PLATIAU, Ana Flávia Barros (Orgs). Princípio da Precaução. Belo Horizonte: Del Rey, 2004, p. 278.

108 RUIZ-FABRI, Hélène. A adoção do princípio da precaução pela OMC in VARELLA, Marcelo Dias e PLATIAU, Ana Flávia Barros (Orgs). Princípio da Precaução. Belo Horizonte: Del Rey, 2004, p. 347.

${ }^{109}$ ALMEIDA, Fernanda Dias Menezes. Op. cit. p. 142.

${ }^{110}$ ALMEIDA, Fernanda Dias Menezes. Op. cit. p. 142.
} 
perquirida sem que, para isso, os munícipes sofram graves prejuízos nas demais esferas de suas vidas.

Nesse sentido também se desenvolve a crítica de Paulo de Bessa

Antunes:

“Tem sido voz corrente que, em tais hipóteses, os Estados deveriam adotar os chamados parâmetros mais restritivos, isto é, o Estado teria o poder de legislar desde que estabelecesse maiores exigências ambientais do que aquelas que são formuladas pela norma federal. O mais restritivo é, como se vê, uma mera petição de princípios, visto que nada assegura que restrições maiores signifiquem que as peculiaridades locais estejam sendo atendidas". 111

O autor ainda complementa suas considerações com um exemplo

para reflexão:

"Imagine-se a repercussão concreta da declaração de constitucionalidade ou inconstitucionalidade de uma norma estadual que determina a preservação, por exemplo, de uma faixa de 300 metros ao redor de reservatórios naturais ou artificiais? Quantos milhares de metros quadrados serão subtraídos às mais diferentes atividades econômicas? Qual o custo social da medida? Do ponto de vista ambiental, ela é necessária?"112

E justamente em razão de poder haver leis inconsistentes, é que se deve fazer uma análise profunda dos fundamentos que embasaram referida lei. No caso citado das metragens, é sabido que elas existem em razão da necessidade de proteção dos cursos d'água e das matas ciliares, de modo que para o aumento das distâncias, deveria haver justificada relacionada à necessidade de melhorar a proteção de uma área determinada. Paulo de Bessa Antunes ainda termina seu raciocínio explicando com distinta clareza a questão:

“A legislação estadual, caso defina distâncias inferiores àquelas contempladas pelo Código Florestas, na hipótese de ser submetida à argüição de inconstitucionalidade, não deverá apenas e simplesmente ser contrastada com as metragens do Código Florestal, mas, em cognição ampla, ser examinada de ponto de vista técnico, de forma a possibilitar que a Corte saiba se a lei atende às finalidades para as

\footnotetext{
${ }^{111}$ ANTUNES, Paulo de Bessa. Op. cit. p. 301.
}

${ }^{112}$ ANTUNES, Paulo de Bessa. Op. cit. p. 308. 
quais foi elaborada e que, razoavelmente, tenha adotado critérios que conjuguem as competências estaduais concorrentes com as realidades econômicas, ambientais e sociais do estado em questão"113 ( (grifos nossos)

O problema dessa análise é que grande parte das leis produzidas no País carecem de fundamentação consistente. Daí a crítica feita pelo mesmo autor:

"Leis ambientais bem concebidas, como se sabe, devem levar em consideração vários fatores: (i) boa técnica jurídica, (ii) informação técnica e científica adequada e (iii) viabilidade econômico-financeira. Infelizmente, o que se tem verificado é a edição de normas que são autoreferenciadas e sem qualquer fundamentação em informações técnicas adequadas, análises econômico-financeiras de sua aplicação, inexistência de previsão de recursos para sua implementação e, igualmente, a inexistência de boa técnica jurídica. Na verdade, uma das características marcantes da legislação ambiental é a pobre técnica jurídica utilizada, tanto no nível federal, quanto nos níveis estaduais e municipais" ${ }^{\text {114 }}$.

Até mesmo nos casos em que tratam de incertezas científicas a respeito dos danos ambientais, a proibição do produto ou atividade não é absoluta. $\mathrm{O}$ próprio princípio da precaução, consagrado na Declaração do Rio de Janeiro - ECO 92, prevê limitações expressas à sua utilização:

"De modo a proteger o meio ambiente, o princípio da precaução deve ser amplamente observado pelos Estados, de acordo com suas capacidades. Quando houver ameaça de danos sérios ou irreversíveis, a ausência de absoluta certeza científica não deve ser utilizada como razão para postergar medidas eficazes e economicamente viáveis para prevenir a degradação ambiental."

Pela leitura da definição do princípio, percebe-se que sua aplicação somente deve ser feita quando houver uma ameaça de danos sérios ou irreversíveis. Assim, exclui-se da abrangência de referido princípio à simples existência de dano leve, assim como quando se tratar de danos reversíveis. Também está limitado pela capacidade de cada Estado, assim como pela viabilidade econômica.

${ }_{113}^{113}$ ANTUNES, Paulo de Bessa. Op. cit. p. 317

${ }^{114}$ ANTUNES, Paulo de Bessa. Op. cit. p. 305. 
Assim, referidos exemplos trazem certa limitação para o ente municipal, de modo que, em cada caso concreto, antes da edição de leis ambientalmente mais protetivas, dever-se-ia verificar se ela iria resultar na melhoria do meio local e da qualidade de vida das pessoas, ou se, na verdade, só traria gravames sociais e econômicos maiores que os benefícios a serem obtidos.

Em suma, tais limites podem ser verificados mais precisamente quando da análise dos casos concretos que são trazidos no próximo capítulo. Para cada caso em que houve votos divergentes nas Ações Diretas de Inconstitucionalidade, foram mencionados os posicionamentos dos votos favoráveis e contrários à constitucionalidade das normas. Assim, pela análise de cada caso será possível verificar, de forma concreta, as eventuais limitações à atuação legislativa municipal, as quais por vezes são mencionadas pelos Desembargadores e Ministros que julgaram tais casos.

\subsection{O controle de constitucionalidade das leis municipais e as espécies de inconstitucionalidades}

Antes de adentrarmos nos casos específicos em que o Judiciário teve que se manifestar sobre o questionamento acerca da (in)constitucionalidade das leis, cumpre lembrar brevemente as diferentes espécies de inconstitucionalidades previstas no ordenamento.

As Ações Diretas de Inconstitucionalidades podem se basear em alegações relacionadas à desconformidade do conteúdo da norma (vício material), como em razão do desrespeito ao procedimento de formação da lei (vício formal), sendo este normalmente relacionado a possíveis equívocos na competência ou por incorreções no processo legislativo em geral.

Diante disso, cumpre destacar que a inconstitucionalidade material (ou nomoestática) é aquela em que há incompatibilidade da matéria da lei com os preceitos constitucionais. Referida espécie de inconstitucionalidade deverá ser declarada quando houver um desrespeito no conteúdo da norma, a qual afronta os princípios ou as regras da Constituição Federal. 
As normas da Lei Maior servem de parâmetro para a edição da legislação infraconstitucional e, portanto, havendo incompatibilidade entre uma e outra, a lei não poderá prevalecer. Um mandamento constitucional só pode ser alterado por Emenda Constitucional e, mesmo assim, elas também devem observar os limites que a própria constituição impõe. Conforme leciona José Afonso da Silva "todas as normas que integram a ordenação jurídica nacional só serão válidas se se conformarem com as normas da Constituição Federal" ${ }^{115}$.

Paulo Bonavides explicita ainda mais as conseqüências da incompatibilidade: "O órgão legislativo, ao derivar da Constituição sua competência, não pode obviamente introduzir no sistema jurídico leis contrárias às disposições constitucionais: essas leis se reputariam nulas, inaplicáveis, sem validade, inconsistentes com a ordem jurídica estabelecida" ${ }^{116}$.

No caso do meio ambiente ecologicamente equilibrado, como foi alçado a direito fundamental dos indivíduos no artigo 225, nem mesmo uma Emenda poderia retirar a proteção deste "bem de uso comum do povo", pois os direitos e as garantias individuais são cláusulas pétreas, conforme a dicção do artigo $60, \S 4^{\circ}$, inciso IV da Constituição.

Assim, o patrimônio ambiental brasileiro está protegido de tal forma que, qualquer tentativa lei ou até de emenda constitucional que contrariasse a proteção do meio ambiente sadio, estaria fadada à inconstitucionalidade material.

Já a inconstitucionalidade formal (ou nomodinâmica), por sua vez, se dá quando na elaboração da lei há um desrespeito ao processo legislativo, isto é, às regras fixadas na Constituição Federal sobre a regular edição das leis.

Há duas subespécies de inconstitucionalidade formal que interessam ao presente trabalho. A primeira é a inconstitucionalidade formal orgânica, que ocorre nos casos em que o órgão legislativo que elaborou a norma não tinha competência para fazê-lo, havendo desrespeito ao pacto federativo estabelecido na Constituição Federal.

Esta espécie de vício certamente é a mais importante para o estudo da competência legislativa do Município em matéria ambiental. Conforme será visto, em todos os casos que serão tratados no próximo capítulo, a discussão principal será a respeito

\footnotetext{
115 SILVA, José Afonso da. Op. cit. p. 46.
}

${ }^{116}$ BONAVIDES, Paulo. Op. cit., p. 297. 
da eventual inconstitucionalidade formal orgânica, pois as Ações Diretas de Inconstitucionalidades sustentam-se justamente na alegação de não possuir o Município competência para instituir tais leis.

Já a segunda espécie de inconstitucionalidade formal é a denominada inconstitucionalidade formal propriamente dita, na qual a lei é editada sem a estrita observância das regras de iniciativa da lei (vício subjetivo) ou de sua tramitação (vício objetivo). Por vezes, nas ações de inconstitucionalidades também é questionada a competência do sujeito que deu início à lei ambiental, ora alegando que competiria ao Executivo Municipal (Prefeito) e não ao Legislativo (Câmara dos Vereadores), ora o inverso.

Ao tratar da inconstitucionalidade formal, Paulo Bonavides assevera que "o exercício deste controle não oferece tantas dificuldades nem alcança grau tão alto de controvérsia como o que decorre do controle material de constitucionalidade" ${ }^{" 17}$. Todavia, não podemos concordar plenamente com referida afirmação. Não obstante a competência material trate muitas vezes de temas criativos e polêmicos, os quais por vezes são decididos de forma mais política que jurídica, é certo que a inconstitucionalidade formal tem recebido cada vez mais questionamentos no Judiciário, havendo comumente grandes divergências em tais julgamentos, inclusive sendo raríssimos os casos com unanimidade nas decisões colegiadas.

Se não bastasse, na maioria das vezes não se mostra fácil, nos casos concretos, fazer uma separação estanque da análise das competências formais e materiais. Referido tema, inclusive, será muito debatido na análise de alguns dos casos que serão doravante analisados.

Todas essas formas de inconstitucionalidades inserem-se na análise do controle de constitucionalidade, que nada mais é que a fiscalização da compatibilidade vertical das leis e atos normativos frente aos princípios e regras da Constituição. Referido controle decorre da rigidez da Constituição Federal de 1988 - já que as mudanças em seu texto somente podem ser feitas por um processo mais dificultoso que o das leis ordinárias (nos termos do artigo $60, \S 2^{\circ}$ ) - bem como em razão de haver supremacia constitucional, uma vez que a Constituição se posiciona no topo do ordenamento jurídico.

${ }^{117}$ BONAVIDES, Paulo. Op. cit., p. 298. 
Especificamente com relação às leis municipais, de acordo com o artigo $125, \S 2^{\circ}$, da Constituição Federal, referido controle em abstrato deve-se fazer como regra em face da Constituição Estadual, pois esta é a "lei maior" dentro de cada Estado da Federação. Tanto é assim que a Constituição Federal prevê que as Ações Diretas de Inconstitucionalidades no Supremo Tribunal Federal só abarcam as leis e atos normativos federais e estaduais (artigo 102, inciso I, alínea “a”), deixando claro não ser cabível, por essa via, a impugnação de lei municipal diretamente no Pretório Excelso.

Assim, os Tribunais de Justiça locais, por meio de seu Plenário ou Órgão Especial, também realizam controle concentrado de constitucionalidade, inclusive proferindo decisões irrecorríveis (em regra), na medida em que o Tribunal de Justiça é o guardião da Constituição Estadual. Somente haverá exceção a esta irrecorribilidade nos casos em que o parâmetro de controle da Constituição Estadual for norma de reprodução obrigatória da Constituição Federal, de forma que em tais casos será admitido Recurso Extraordinário ao Supremo Tribunal Federal.

Outra possibilidade de controle concentrado de lei municipal seria por meio da Argüição de Descumprimento de Preceito Fundamental (ADPF), nos termos do artigo $1^{\circ}$, inciso I, da Lei $n^{\circ} 9882 / 99$. No caso, referida ação de inconstitucionalidade permite uma ampliação do objeto de controle tanto para as normas municipais como para aquelas produzidas anteriormente à Constituição, as quais não podem ser objeto de Ações Diretas de Inconstitucionalidade. Por outro lado, referida ação constitucional possui um parâmetro de controle mais restrito, pois ela não é admitida contra ofensa a todas as normas da Constituição Federal, mas somente contra os preceitos fundamentais.

Em que pese a Constituição e a lei não tenham definido o que seriam tais preceitos fundamentais, a doutrina e a jurisprudência do Supremo Tribunal Federal têm se manifestado a respeito do tema, em regra relacionando-os às questões vitais do regime democrático, aos direitos e garantias individuais e aos princípios constitucionais sensíveis (artigo 34, inciso VII, da Constituição).

Como exemplo de preceito fundamental relacionado ao presente trabalho, pode-se mencionar a repartição de competências entre os entes federados, seja por estar afeto ao federalismo, seja porque a autonomia municipal foi erigida a princípio constitucional sensível (artigo 34, inciso VII, alínea “c”, da Constituição Federal). 
Além disso, tratando-se de ação afeta ao meio ambiente, por si só já seria possível o manejo da ADPF, pois o meio ambiente ecologicamente equilibrado é um direito fundamental da pessoa humana (artigo 225 da Constituição), de modo que também poderá ser considerado um preceito fundamental. Inclusive, nesse sentido foi a posição do próprio Supremo Tribunal Federal no julgamento da Argüição de Descumprimento de Preceito Fundamental nº 101.

Referida ação questionava a constitucionalidade da lei que proibia a importação dos pneumáticos usados, sendo expressamente declarado pela Corte Suprema que tanto o meio ambiente ecologicamente equilibrado como a saúde humana são preceitos fundamentais e merecem a devida proteção. Sob esse fundamento, autorizaram a manutenção da proibição para que o Brasil não recebesse "sucata ambiental".

Logo, seja para a proteção da autonomia municipal, seja para a necessária proteção do meio ambiente, também será cabível a Argüição de Descumprimento de Preceito Fundamental.

Passando para o controle difuso de constitucionalidade, cumpre lembrar que sempre será possível a alegação de inconstitucionalidade de lei de forma incidental, como causa de pedir em uma ação concreta perante qualquer juiz ou tribunal. Em tais casos, somente é afastada a lei incompatível com a Constituição num determinado caso concreto, não produzindo efeito vinculante nem erga omnes.

Assim, o controle incidental somente terá maior repercussão para a sociedade quando for utilizado nas ações civis públicas, pois em que pese não haja exclusão por completo da lei, ela será afastada parcialmente diante de uma situação concreta de atendimento ao interesse público.

Poder-se-á demandar, por exemplo, a não aplicação de uma lei municipal num determinado caso concreto, quando houver afronta ao meio ambiente ecologicamente equilibrado. O que não se pode admitir é a utilização de Ação Civil Pública como sucedâneo de Ação Direta de Inconstitucionalidade, pois nesse caso estaria havendo usurpação tanto do legitimado ativo, como do órgão competente para julgamento.

Em suma, diante de todo exposto, percebe-se que as diferentes espécies de inconstitucionalidades podem ser argüidas de diferentes formas perante o Poder Judiciário. Com a utilização de qualquer das ações supramencionadas, poderá ser 
buscado um pronunciamento judicial a respeito da (in)constitucionalidade das leis municipais ambientais. 


\section{Capítulo 4 - CASOS REPRESENTATIVOS DA DISCUSSÃO}

\subsection{A proibição da queima da palha da cana-de-açúcar}

Um caso que bem representa a controvérsia tratada nesta dissertação se refere à possibilidade dos Municípios criarem leis que proíbam a queima da palha da cana-de-açúcar, especialmente por ser considerada uma atividade nociva ao meio ambiente e à saúde da população local.

Esse é um dos temas que mais motivou discussão sobre repartição de competência legislativa no Tribunal de Justiça paulista nos últimos anos. E o debate principal se dá justamente na divergência acerca da (in)constitucionalidade de tais leis ambientais, as quais são atacadas por supostamente ferirem a divisão constitucional das competências legislativas.

Nos vários casos julgados, os argumentos de ambos os lados são muito consistentes. Como primeiro exemplo, na ADI n.163.415-0/4-00 ${ }^{118}$ referente à lei proibitiva do Município de Cedral, o Órgão Especial do Tribunal de Justiça do Estado de São Paulo entendeu, por maioria, que tal legislação municipal estaria usurpando a competência da União/Estados, de modo que seria formalmente inconstitucional.

No entanto, tal entendimento não restou pacificado. Muito pelo contrário, o julgamento acabou com 13 (treze) Desembargadores aliados a tese vencedora e 11 (onze) Desembargadores vencidos, o que demonstra a necessidade de se analisar os argumentos lançados nos diferentes votos para se possibilitar uma compreensão melhor acerca do porquê de tanta divergência.

No voto vencedor do Desembargador Luis Elias Tamabra, restou consignado que:

"Não só a União como o Estado de São Paulo, no exercício da competência que lhes foi exclusivamente reservada pelo inciso VI do artigo 24 da Constituição Federal, editaram normas disciplinando

\footnotetext{
${ }^{118}$ ADI 163.415-0/4-00, Rel. Desembargador José Reynaldo, Órgão Especial do Tribunal de Justiça de São Paulo, julgado em 26/11/2008.
} 
minuciosamente o emprego do fogo em práticas agropastoris, mediante queima controlada e sua eliminação de forma gradativa, como método despalhador e facilitador do corte de cana-de-açúcar em áreas passíveis de mecanização da colheita".

Nesse raciocínio, o papel do Município seria de tão somente suplementar a legislação federal e estadual no que couber, de maneira restrita, de complementação, mas não de modo contrário ao já estabelecido. Assim, foi dado prevalência ao argumento de que apenas a União e o Estado têm competência para legislar sobre meio ambiente, na medida em que o Município não poderia ir de encontro à Lei Estadual 11.241/02, que permite o uso do fogo na colheita.

Ao final, lembra o voto vencedor do Desembargador Eros Piceli que, no campo do meio ambiente, não se pode confundir interesse peculiar do Município com a tentativa de legislar em sentido contrário ao Estado, ainda mais porque "bem ou mal, existe lei estadual (...), que dispõe sobre a matéria de queima da palha da cana-de-açúcar, de modo que os municípios não podem estabelecer lei em sentido contrário.”

Nos demais votos no mesmo sentido, sempre é lembrado que tanto a separação dos Poderes como a repartição de competências são fundamentais no regime federativo. Dessa forma, entendem que por a matéria da queimada estar disciplinada em Leis Estadual, não competiria ao Município dispor de forma diversa. A vedação municipal não poderia afrontar, assim, a permissão estabelecida pelo Estado, ente federal competente para legislar sobre o assunto.

Nesse sentido foi complementado pelo Desembargador Walter de Almeida Guilherme, ao buscar evitar a disparidade de legislação:

\footnotetext{
"Um município permite as queimadas nas áreas rurais para a colheita da cana-de-açúcar e o outro não. A necessidade de uniformização das práticas dos municípios referentes ao tema é que ditou que a competência para legislar fosse de caráter mais abrangente. Se, para a defesa do meio ambiente, é necessário proibir as queimadas, a União e os Estados podem emitir leis nesse sentido".
}

Concluindo o raciocínio, é demonstrado no Acórdão que o Município não pode, a pretexto de exercer a sua competência supletiva ou complementar, legislar sobre Direito Ambiental com inobservância dos princípios gerais e das diretrizes fixadas pela União Federal e pelo Estado-membro. Portanto, seria possível o entendimento 
de que a atribuição de competência legislativa da União não exclui a do Município, embora este não possa contrariá-la.

Além disso, consignou o voto vencedor que se deve dar destaque para o fato de que a questão não seria de hierarquia, mas sim de competência, de modo que citou trecho da doutrina de Luís Roberto Barroso "se a União extrapolar as normas gerais e ingressar na regulamentação específica da matéria, a lei federal não prevalecerá”.

Importante ainda a menção de trecho de seu voto sobre o contexto maior da questão: "se não cuidarmos do meio ambiente, com ele pereceremos, não devendo o tema ser tratado de forma paroxística, num inconseqüente maniqueísmo de ser "a favor ou contra o meio ambiente", mas sim dentro das normas constitucionais que definem a distribuição de competências para os entes federativos." Assim, alega que a busca da proteção ambiental sempre deveria ser realizada com a observância dos ditames da Constituição Federal.

Posteriormente, o Desembargador Walter de Almeida Guilherme reforça seu voto com a citação de Pontes de Miranda: "Onde a legislação estadual contradiz as normas gerais editadas pela legislatura central, se anterior, está revogada; se posterior, peca pela inconstitucionalidade' (Comentários à Constituição de 1946, 4a ed., Borsoi, 1963, t I, art. 5º n 31, pág. 458)”.

Referido Desembargador busca salientar os benefícios da queima da cana, a qual seria solicitada pelos próprios trabalhadores rurais, pois a queima afastaria cobras e escorpiões, além de facilitar o corte da cana-de-açúcar. Ao final lança um argumento puramente econômico, segundo o qual os dirigentes das empresas saberiam o que fazer para alcançar o lucro: "Se houvesse possibilidade de se proceder de forma diversa e ainda obter lucro, os empresários do setor por certo já teriam agido dessa forma, pois a busca do lucro passa pela competência e pela boa administração do negócio”.

Nesta linha também foi o entendimento do Desembargador Torres de Carvalho, ao relatar o Agravo $\mathrm{n}^{\circ} 436.156 .5 / 4-00^{119}$ da Comarca de Limeira, segundo o qual a lei proibitiva da queima da palha da cana implicaria em vultosos investimentos por parte das empresas do setor, inclusive alterando as relações dos trabalhadores locais.

\footnotetext{
${ }^{119}$ Agravo de Instrumento ${ }^{\circ}$ 436.156.5/4-00, Rel. Desembargador Torres de Carvalho, Câmara Especial do Meio Ambiente do Tribunal de Justiça de São Paulo, julgado em 21/09/2006.
} 
Se não bastasse, referido Desembargador afirma que não há "conclusão confiável quanto aos reais efeitos deletérios da queimada ao meio ambiente e à saúde humana". Ainda sopesa que haveria grande prejuízo econômico e social com a proibição, pois aumentaria muito o desemprego do trabalhador rural, bem como não haveria tecnologia disponível para a prática sem a queima.

Tais argumentos, em síntese, foram repetidos para repelir leis que proibiam a queima da palha em vários Municípios paulistas, o que fez o Judiciário afastar a vigência das leis municipais de Cedral, Mogi Mirim, Ribeirão Preto, Americana, São José do Rio Pardo entre outras.

De outro lado, os 11 Desembargadores que se declaram vencidos na referida ADI $n^{\circ}$ 163.415-0/4-00 do Município de Cedral, discordaram dos argumentos expostos pelos votos vencedores, de modo que votaram pela constitucionalidade da lei que proibiu a queima da palha da cana-de-açúcar no Município.

O Desembargador Ivan Sartori, hoje Presidente do Tribunal de Justiça, buscou defender que a generalidade do tema nas normas estaduais autorizariam a lei municipal que proíbe a queima da palha da cana, sendo estas constitucionais:

"É que, além de dispor sobre a competência dos Municípios para legislar acerca de assuntos de interesse local, a Constituição Federal previu a possibilidade de aquelas Autonomias suplementarem a legislação federal e estadual, no que couber (art. 30, incisos I e II), a par de lhes atribuir competência concorrente para a proteção do meio ambiente e combate da poluição em qualquer de suas formas (art. 23, VI)".

$\mathrm{Na}$ Ação Direta de Inconstitucionalidade n. 125.060-0/5-00 ${ }^{120}$, referente à lei proibitiva de Ribeirão Preto, houve declaração de voto vencido do Desembargador e Professor Gilberto Passos de Freitas, no qual restou demonstrado que há ampla doutrina defendendo a constitucionalidade das leis municipais em favor do meio ambiente. Isso porque o poder-dever de todo o Poder Público defender e preservar o meio ambiente (artigo 225 da Constituição Federal), assim como a competência material dos Municípios para proteger o meio ambiente (artigo 23 da CF), legitimariam este ente federativo na produção de leis que almejassem esta finalidade.

Além disso, segundo mencionado Desembargador:

${ }^{120}$ ADI n. 125.060-0/5-00, Rel. Desembargador Debatin Cardoso, Órgão Especial do Tribunal de Justiça de São Paulo, julgado em 24/01/2007. 
"considerando-se que os Municípios detêm melhores condições para detectar as agressões ao meio ambiente e adotar com mais eficácia as medidas protetivas cabíveis, de inteira aplicação o princípio da subsidiariedade”. Assim, conclui que é de interesse local do Município a questão relativa à queima da cana, razão pela qual afastou a inconstitucionalidade formal da lei municipal proibitiva".

Da análise geral de outros votos divergentes em Ações Diretas de Inconstitucionalidades contra leis semelhantes, pode-se perceber alguns argumentos sempre presentes. Em breve síntese, é lembrado que diante das conseqüências nefastas do procedimento da queima, o Município estaria autorizado a legislar com amparo do artigo 30, inciso I e II, da Constituição Federal, em defesa do interesse local, do território e dos cidadãos.

Com relação ao interesse local do Município para legislar, é argumentado que estaria presente na medida em que a queimada colocaria em risco não só a saúde, mas também a segurança de todos os munícipes.

Além do interesse local devidamente comprovado, argumentam que a suplementação da legislação federal e estadual (artigo 30, inciso II da Constituição) poderia antecipar o fim da queima previsto na Lei e no Decreto Estadual. Se no plano regional a eliminação será gradativa, nada impediria que um Município antecipasse a proibição da queima da palha de cana-de-açúcar na defesa dos interesses locais.

Normalmente também é rebatida a tese de que a queimada seria feita em prol dos trabalhadores, especialmente pelas péssimas condições de trabalho em que eles se encontram. Na verdade, para se buscar uma atividade que seja socialmente justa, o empresário deveria buscar a qualificar a da mão-de-obra lá utilizada e a melhoria das condições de trabalho.

Dessa forma, a queima da palha da cana é vista como uma prática que atende somente aos interesses dos plantadores, pois ela facilitaria e baratearia o corte manual, aumentando a produtividade, diminuindo os custos e melhorando o transporte da cana.

Referida facilitação compensaria, sob a ótica econômica dos empresários, todo o gás carbônico, ozônio, gás de nitrogênio, enxofre e a fuligem. Se não 
bastasse, os prejuízos ao solo e a microbiota também são lembrados, haja vista que é aumentada a erosão e lixiviação no local das queimadas.

Já na Ação Direta de Inconstitucionalidade n. 994.09.001612-2 $2^{121}$, sobre lei semelhante na comarca de Uchoa, também houve a declaração expressa de inúmeros votos divergentes que merecem ser brevemente analisados.

A linha de argumentação utilizada pelo Desembargador Souza Lima nesta ADI foi a da compatibilização das leis municipais com a Constituição Estadual de São Paulo, especialmente com seu artigo 191:

“O Estado e os Municípios providenciarão, com a participação da coletividade, a preservação, conservação, defesa, recuperação e melhoria do meio ambiente natural, artificial e do trabalho, atendidas as peculiaridades regionais e locais e em harmonia com o desenvolvimento social e econômico".

Já o voto do Desembargador Barreto Fonseca assentou que a prática da queimada até dispensaria prova dos malefícios e inconvenientes trazidos ao bem-estar público, especialmente pensando na população que reside na periferia das cidades canavieiras. Assim, diante da força normativa do caput e $\S 3^{\circ}$ do artigo 225 da Constituição Federal, os órgãos integrantes do SISNAMA (no caso, a CETESB) jamais poderiam afrontá-lo e permitir as queimadas.

Asseverou, assim, que "não se pode negar que existe o meio ambiente para o homem, e não o homem para o meio ambiente, de sorte que esse deve ser sacrificado, quando preciso, em favor daquele. Todavia, possível o corte da cana sem que se queime a palha."

Especificamente no voto divergente do Desembargador Renato Nalini nesta ADI de Uchoa, foram trazidas inúmeras considerações que não podem ser desconsideradas a respeito do tema. De maneira firme, o Desembargador criticou a posição vencedora no Tribunal: "Ouso divergir da Douta Maioria, que se apegou ao vetusto critério do princípio da Separação dos Poderes para prover a pretensão dos sindicatos autores."

Explicando melhor seu ponto de vista, afirmou que as leis locais são fruto de grande descontentamento popular com os malefícios das queimadas,

\footnotetext{
${ }^{121}$ ADI n. 994.09.001612-2, Rel. Desembargador Souza Lima, Órgão Especial do Tribunal de Justiça de São
} Paulo, julgado em 03/11/2010. 
demonstrando que os Municípios que proíbem "sabem o que significa a reiteração da prática primitiva que é a queimada".

Já quanto à possibilidade do Município ser mais restritivo, recordou o Desembargador que não haveria qualquer novidade nesta prática:

"o Direito Urbanístico sempre reconheceu a cada cidade - e isso mesmo sob a ótica da normatividade fundante anterior a 1988 - restringir a ocupação do solo dentro de seus lindes. Proibido seria atenuar as exigências da Lei 6766/79, a Lei Lehman, do parcelamento do solo. Nunca se questionou a licitude de a lei municipal fixar parâmetros mais severos do que a lei federal. Sempre em nome do peculiar interesse do Município."

Nessa linha de raciocínio, asseverou que não haveria porque não seguir o mesmo entendimento para direitos tão semelhantes. Criticou, ainda, a proibição eufemística da lei estadual, a qual ao mesmo tempo veda a prática da queimada, mas também assegura uma leniência desproporcional com os danos causados à saúde e à qualidade de vida dos munícipes.

Somado a isso, o Desembargador Renato Nalini também consignou que a doutrina vem admitindo que o Município possua uma competência legislativa suplementar pelo interesse local. Diante de sua ótica mais abrangente, ainda lembrou que:

"a tutela ao ambiente encontra-se inevitavelmente inserida na competência constitucional atribuída aos municípios de promoção do adequado ordenamento territorial, mediante planejamento e controle do uso, parcelamento e ocupação do solo urbano (art. 30, inciso VIII) bem como para a elaboração da Política de Desenvolvimento Urbano e do Plano Diretor (art. 182).”

Argumentou que em razão do meio ambiente inserir-se no espaço urbano, a Política de Desenvolvimento Urbano e o Plano Diretor deveriam abranger uma perspectiva ambiental. Se isso não bastasse, foi exposto que a população das cidades do interior paulista continua sofrendo - e muito - com os resultados da queima da cana. $\mathrm{O}$ alto índice de emissão de gás carbônico na atmosfera agrava não só os problemas climáticos, como também as doenças respiratórias da população local.

Assim, buscou demonstrar que a proibição da queima da palha de cana-de-açúcar feita por lei municipal mostra-se em completa harmonia com a 
Constituição Federal, uma vez que a saúde é direito de todos e dever do Estado (artigo 196). Somado a tal fato, asseverou que deveriam ser garantidas políticas sociais e econômicas que busquem a redução do risco de doenças respiratórias, haja vista a grande exposição ao ar poluído decorrente da queima com que a população é obrigada a conviver periodicamente.

O mencionado Desembargador Nalini ainda citou trechos de precedentes no mesmo sentido do próprio Órgão Especial do Tribunal de Justiça de São Paulo:

“(...) entre o princípio federativo e o princípio da tutela ao meio ambiente, este se sobrepõe ao primeiro, mesmo porque, o direito fundamental ao meio ambiente saudável é o primeiro interesse intergeracional explicitado pelo constituinte. Na ponderação de valores principiológicos proposta por Canotilho, a dimensão deste se encontra a anos-luz em relevância, se cotejado com o formalismo das competências federativas" $" 122$.

Nesse sentido, afirmou que a legislação estadual específica é claramente genérica, de modo que somente seria aplicada quando ocorrer lacuna da legislação local. Para reforçar tal tese, recordou a lição do professor Toshio Mukai ao tratar da autonomia municipal e da legislação sobre o meio ambiente: "a competência do Município é sempre concorrente com a da União e a dos Estados-membros, podendo legislar sobre todos os aspectos do meio ambiente, de acordo com a autonomia local (Legislação, Meio Ambiente e Autonomia Municipal. Estudos e Comentários)”.

Passando para uma análise de caráter mais principiológico, referido Desembargador ressaltou a necessidade de observância dos valores constitucionais, assegurando uma efetividade ótima que muito depende dos tribunais para ser alcançada. Assim, a hermenêutica da norma somente seria adequada e justa se não se baseasse exclusivamente na literalidade das normas, mas sim na prevalência dos princípios. Assim, o magistrado deveria perceber o que a Constituição quis dizer quando converteu o meio ambiente em direito fundamental para as presentes e futuras gerações, e somente a partir desta vertente interpretativa poderia se solucionar uma ponderação de princípios.

122 ADI 126.780-0/8-00, Rel. Desembargador Renato Nalini, Órgão Especial do Tribunal de Justiça de São Paulo, julgado em 24/10/2007. 
Baseado nas teses de J.J. Gomes Canotilho e Ronald Dworkin, o Desembargador Nalini finaliza seu voto no sentido da transformação dos direitos fundamentais em valores fundamentais, bem como na democratização da Constituição quando o Judiciário recebe soberania para interpretá-la de maneira construtiva. Assim, conclui pela compatibilidade da lei proibitiva da queima da cana com a ordem constitucional, especialmente em razão da inequívoca intenção da Constituição em enfatizar a tutela ao meio ambiente.

Finalmente, lembrou que o povo, verdadeiro titular do poder constituinte, vem aplaudindo as leis proibitivas das queimadas, de forma que não mais se poderia deixar nossa democracia semi-direta atada ao simples direito de votar no dia das eleições. Assim, dever-se-ia levar em conta o interesse da população local no controle de constitucionalidade exercido pelo Judiciário, sopesando tal fator conjuntamente com o Estado Democrático de Direito, alcançando uma harmonia da norma. Ao revés, a "falta de sincronia apenas intensificaria a consistência da argumentação de que o Judiciário, por sofisticar-se e sufocar-se em erudição, distanciou-se do povo, precípuo destinatário de seu mister e finalidade última para a qual esse Poder do Estado foi preordenado".

Diante dos robustos argumentos ora analisados, em outras quatro ações um pouco mais antigas que envolviam exatamente o mesmo tema, o Órgão Especial tomou decisão diametralmente oposta aos casos de Cedral e Uchoa, haja vista que declarou constitucionais as leis de Paulínia, Limeira, São José do Rio Preto e Botucatu. Assim, divergindo de todos os primeiros argumentos citados, a posição que vinha prevalecendo até alguns anos atrás no Tribunal de Justiça do Estado de São Paulo era pela constitucionalidade das leis municipais proibitivas.

No entanto, como recentemente o posicionamento majoritário do referido Órgão Especial tem se mostrado contrário à constitucionalidade destas leis municipais, a busca pela cessação dos malefícios sobre a queima da palha da cana acabou chegando novamente ao Judiciário por meio de outras ações que não as de inconstitucionalidade. Em que pese não ser o objeto direto deste trabalho a análise das tentativas de proibições das queimadas, cumpre mencionar algumas iniciativas tomadas como reação às inconstitucionalidades decretadas pelo Tribunal de Justiça paulista.

A Justiça Federal de São Paulo, por exemplo, proibiu a queima da palha de cana-de-açúcar na safra de 2012/13 em pelo menos dez cidades do interior paulista, proibindo-se a Cetesb de conceder autorizações para esse fim às usinas de Franca, 
Cristais Paulista, Itirapuã, Jeriquara, Patrocínio Paulista, Restinga, Ribeirão Corrente, Rifaina, São José da Bela Vista e Pedregulho.

Também foi determinado pela Justiça Federal de São Paulo que as permissões para queimadas só poderão ser dadas mediante elaboração de estudos de impacto ambiental para as cidades de Piracicaba, Águas de São Pedro, Charqueada, Limeira, Santa Bárbara d'Oeste, entre outras cidades.

Já no Município de Jaú a proibição decorreu de uma Ação Civil Pública movida pelo Ministério Público local. Apesar do Tribunal de Justiça local ter sido favorável aos argumentos da Municipalidade e do Estado de São Paulo, o Superior Tribunal de Justiça (STJ) deu provimento ao Recurso Especial (REsp n ${ }^{\circ} 1.285 .463^{123}$ ) do Ministério Público de São Paulo para proibir a queima da palha para o preparo da colheita da cana-de-açúcar na região de Jaú.

Foi narrado pelo Ministério Público que, todos os anos, no período da safra da cana, mesmo acarretando graves danos ambientais o fogo seria largamente utilizado para a limpeza do solo e facilitação do preparo do plantio e colheita da cana. Assim, buscou o Parquet local a condenação do Estado, na obrigação de não fazer consistente na abstenção da concessão de novas autorizações de queimadas nos canaviais de Jaú, sob pena da cominação de astreinte.

O Tribunal de Justiça, primeiramente, considerou que o ordenamento jurídico admite a prática da queima da cana, sendo tolerada em todo o Estado de São Paulo. Além disso, negou provimento a ação em razão da suposta incerteza de que a queimada cause degradação ambiental e malefícios à saúde do homem, afrontando diretamente os ditames do princípio da precaução.

Diante disso, o Recurso Especial interposto pelo Ministério Público no Superior Tribunal de Justiça buscou demonstrar que a decisão do Tribunal bandeirante desconsiderou o previsto no artigo 225 da Constituição e toda a legislação ambiental infraconstitucional, especialmente sobre o mandamento de prevenção e reparação dos danos causados ao meio ambiente.

\footnotetext{
${ }^{123}$ Recurso Especial no 1.285.463, Rel. Ministro Humberto Martins, Segunda Turma do Superior Tribunal de Justiça, julgado em 28/02/2012.
} 
Foi sustentada a ofensa à Política Nacional do Meio Ambiente (Lei $\mathrm{n}^{\circ}$ 6.938/81), na medida em que define poluidor como toda pessoa responsável direta ou indiretamente por atividades causadoras de degradação ambiental.

Argumentou-se que a própria Lei Estadual no 10.547/00 autorizadora da queimada é que seria inconstitucional ao autorizar o emprego de fogo nas atividades agropastoris, por afronta à higidez ambiental e aos ditames constitucionais e infraconstitucionais.

Dentre os malefícios da prática da queima da cana, a Ação Civil Pública deu especial atenção para a matança de animais, quebrando o ciclo animal, além dos danos ao meio ambiente, à saúde das pessoas, e toda a fauna e flora local, especialmente em razão da liberação de material particulado e de vários gases nocivos à saúde.

Diante disso, o Superior Tribunal de Justiça houve por bem se alinhar ao princípio da precaução, asseverando o Ministro Humberto Martins que a ausência de certeza científica não poderia ser argumento para postergar a adoção de medidas eficazes de proteção ambiental (in dubio pro ambiente).

O acórdão mencionou que a permissão para a queima da palha da cana somente poderia ser dada se em caráter específico, sempre precedida de Estudo de Impacto Ambiental (EIA) num processo de licenciamento, com vistas a implementação de todas as medidas cabíveis para amenizar os dados e a recuperar o meio ambiente.

A propositura de referida Ação Civil Pública está em consonância com o entendimento dos órgãos superiores do Ministério Público do Estado de São Paulo, tanto é assim que foi editada a Súmula 22 do Conselho Superior neste sentido:

"Justifica-se a propositura de ação civil pública de ressarcimento de danos e para impedir a queima da cana-de-açúcar, para fins de colheita, diante da infração ambiental provocada, independentemente de situar-se a área atingida sob linhas de transmissão de energia elétrica, ou estar dentro do perímetro de $1 \mathrm{~km}$ da área urbana" ${ }^{, 24}$.

O fundamento expresso utilizado para embasar a súmula é ainda mais contundente: "Os mais atuais estudos ambientais têm demonstrado a gravidade dos danos causados

\footnotetext{
${ }^{124}$ MAZZILLI, Hugo Nigro. A Defesa dos Interesses Difusos em juízo. 24ªed. São Paulo, Saraiva, 2011, p.
} $803 / 804$. 
pela queimada na colheita da cana-de-açúcar ou no preparo do solo para plantio. Assim, em sucessivos precedentes, o Conselho Superior tem determinado a propositura de ação civil pública em defesa do meio ambiente degradado" 125 .

Em suma, o atual quadro do Estado de São Paulo no plano legislativo é o de que a queima da palha da cana continua regulada pela Lei 11.241/02 e pelo Decreto 47.700, de março de 2003. De acordo com a legislação, o processo será substituído totalmente, de forma gradativa, em um prazo de 30 anos. Após essa data, será obrigatório o cultivo mecanizado de cana crua.

Por outro lado, recentemente houve alguns avanços nessa questão: o primeiro foi o Protocolo Agroambiental firmado em 2007, no qual os produtores de cana de São Paulo se comprometeram a antecipar a eliminação da queima da cana até 2014 nas áreas mecanizáveis e até 2017 nas áreas não-mecanizáveis.

O segundo foi a edição da Resolução SMA 40, de 22 de maio de 2013, da Secretaria de Estado do Meio Ambiente, que proíbe a queima da palha de cana de $1^{\mathrm{o}}$ de junho até 30 de novembro, no período das $6 \mathrm{~h}$ às $20 \mathrm{~h}$, assim como proíbe em qualquer horário a queima se a umidade do ar estiver inferior a 20\%. Assim, busca-se a suspensão da queima quando as condições atmosféricas do local estiverem desfavoráveis, com vistas a melhor salvaguardar a qualidade de vida e a saúde da população local.

Finalmente, foi reconhecida repercussão geral pelo Supremo Tribunal Federal a respeito do tema da queima da palha da cana-de-açúcar na Ação Direta de Inconstitucionalidade referente à Lei de Paulínia. Sendo esta uma das ações em que o Tribunal de Justiça paulista decidiu pela constitucionalidade da lei municipal, tanto o Estado de São Paulo, como o Sindicato da Indústria do Álcool interpuseram Recurso Extraordinário no STF (RE n. 586.224).

Em 28 de fevereiro de 2013 foi realizada audiência pública sobre a questão, no qual inúmeras pessoas com notória representatividade e especialização técnica manifestaram-se sobre os benefícios e malefícios das queimadas. Em breve, o órgão de cúpula do Judiciário deverá solucionar a questão, decisão esta que certamente influenciará todas as futuras ações de inconstitucionalidade referentes ao tema.

${ }^{125}$ MAZZILLI, Hugo Nigro. Op. cit. p. 804. 


\subsection{A proibição do uso das sacolas plásticas}

Dentre os casos analisados especificamente neste capítulo, as leis municipais que proíbem as sacolas plásticas certamente representam um dos temas com mais relevância no dia a dia das pessoas que vivem no meio urbano. Recentemente, este também foi um dos assuntos que mais gerou polêmica na imprensa e no cotidiano das pessoas, notadamente na cidade de São Paulo, em razão da paralisação de distribuição das sacolas plásticas nos supermercados por alguns meses durante o início do ano de 2012.

Como é sabido, as sacolas plásticas estão na mira dos defensores do meio ambiente por inúmeras razões, dentre as quais se destaca o fato de elas serem uma das principais responsáveis pelo entupimento de bueiros e galerias de água pluvial, contribuindo para as enchentes.

Referida conseqüência se dá não só pela cobertura dos bueiros pela sacola plástica em si, mas também porque, apesar de não terem sido produzidas para acondicionar o lixo doméstico, elas são comumente utilizadas com essa finalidade. E por serem frágeis, rompem-se com facilidade e acabam por deixar o lixo vazar para os bueiros e rios, o que em muito agrava o já endêmico problema das enchentes em nossas cidades.

No mais, alguns estudos apontam que muito desse material plástico vai parar nos oceanos, sendo lá ingerido por diferentes espécies marinhas (tartarugas, golfinhos, baleias etc), que as confundem com alimentos e acabam se sufocando, sem falar das gigantescas ilhas artificiais de lixo plástico que têm sido descobertas nos oceanos.

Segundo relatório do Programa Ambiental das Nações Unidas ${ }^{126}$, a cada ano os detritos plásticos são responsáveis pela morte de 1 milhão de pássaros marinhos, 100 mil mamíferos aquáticos e inúmeros peixes. Se não bastasse, os detritos de plástico ainda correspondem a $90 \%$ do lixo flutuante nos oceanos ${ }^{127}$.

Além disso, por ser o plástico proveniente do petróleo, a produção das sacolas plásticas acaba por provocar a emissão de gases de efeito estufa que contribuem para o aquecimento do planeta.

\footnotetext{
${ }^{126} \mathrm{http}: / /$ noticias.terra.com.br/ciencia/interna/0,,OI1043962-EI299,00.html. Acesso em 26/02/2013.

${ }^{127} \mathrm{http}: / /$ planetasustentavel.abril.com.br/noticia/ambiente/conteudo_269410.shtml. Acesso em 26/02/2013.
} 
A insistência de inúmeros setores da sociedade civil - notadamente os ambientalistas - na cobrança de uma solução às externalidades negativas resultantes da disposição inadequada das "sacolinhas", acabou por sensibilizar a Câmara Municipal da cidade da capital paulista. Preocupados com os malefícios causados por milhões de sacolas plásticas distribuídas diariamente somente na cidade de São Paulo, foi editada a Lei Municipal no $15.374 / 11$.

Referida lei iniciaria sua vigência a partir de janeiro de 2012, estabelecendo em seu artigo $1^{\circ}$ : "Fica proibida a distribuição gratuita ou a venda de sacolas plásticas para os consumidores para o acondicionamento e transporte de mercadorias adquiridas em estabelecimentos comerciais no Município de São Paulo". E no seu parágrafo único: "Os estabelecimentos comerciais devem estimular o uso de sacolas reutilizáveis, assim consideradas aquelas que sejam confeccionadas com material resistente e que suportem o acondicionamento e transporte de produtos e mercadorias em geral."

Diante da magnitude dos efeitos dessa lei cidade mais populosa do Brasil, as impugnações à norma vieram antes mesmo de sua entrada em vigor. Primeiramente, foi impetrado o Mandado de Segurança Coletivo $n^{\circ}$ 027335494.2011.8.26.0000 ${ }^{128}$, no qual se sustentou que a lei violaria direito líquido e certo dos associados do impetrante. No entanto, conforme muito bem constatado pelo Desembargador relator Carlos Augusto de Santi Ribeiro, a pretensão objetivava, na verdade, a declaração de ineficácia da lei sem qualquer indicação de situação concreta.

Assim, o diploma legal deveria ser objeto de controle de constitucionalidade em ação direta, sendo o mandado de segurança coletivo uma via inadequada para a pretensão deduzida. Este posicionamento, inclusive está baseado na Súmula n. 266 do STF: "Não cabe mandado de segurança contra lei em tese". Portanto, a ordem restou devidamente denegada.

Todavia, ainda antes do início da vigência de referida lei, o Sindicato da Indústria de Material Plástico do Estado de São Paulo ajuizou a Ação Direta de Inconstitucionalidade $\mathrm{n}^{\mathrm{o}}$ 0121480-62.2011.8.26.0000 ${ }^{129}$ perante o Tribunal de Justiça do Estado de São Paulo. Nesta ação, o Desembargador relator Luiz Pantaleão deferiu a liminar para sustar a eficácia da lei, com efeitos erga omnes, baseado nos precedentes

\footnotetext{
${ }^{128}$ Mandado de Segurança Coletivo n 0273354-94.2011.8.26.0000, Rel. Desembargador Carlos Augusto de Santi Ribeiro, Órgão Especial do Tribunal de Justiça de São Paulo, julgado em 21/09/2006.

129 Ação Direta de Inconstitucionalidade $\mathrm{n}^{\mathrm{o}}$ 0121480-62.2011.8.26.0000, Rel. Desembargador Luiz Pantaleão, Órgão Especial do Tribunal de Justiça de São Paulo, julgado em 20/06/2011.
} 
favoráveis à tese da inicial (a exemplo das ADIs 0230258-97.2009.8.26.0000, 903186488.2009.8.26.0000 e 0038637-74.2010.8.26.0000). Assim, mesmo com a interposição de Agravo Regimental, a decisão foi mantida.

Irresignada, a Câmara de São Paulo tentou reverter tal decisão com o ajuizamento da Reclamação n. $13818^{130}$ perante o Supremo Tribunal Federal. No entanto, a liminar não foi concedida pelo Ministro Ricardo Lewandowski, sob o argumento de não haver de periculum in mora a justificar a suspensão do ato reclamado.

Os principais argumentos utilizados para embasar o pedido da Ação Direta de Inconstitucionalidade contra a lei paulistana foram: que a Câmara Municipal não teria competência para elaborar referida lei; que haveria fumus boni iuris, representado pelos inúmeros acórdãos do Colendo Órgão Especial no sentido da inconstitucionalidade de leis municipais semelhantes; e que estaria presente o periculum in mora, pois caso a lei entrasse em vigor, as empresas produtoras de materiais plásticos teriam que suspender as importações, as aquisições de máquinas, os moldes e toda a matéria-prima, o que em muito aumentaria a taxa de desemprego do setor.

Em sede de liminar, foram acolhidos os questionamentos acerca da inconstitucionalidade da norma, de modo que o relator deu provimento ao pedido do sindicato e suspendeu a eficácia da lei até o julgamento do mérito do recurso. Tal decisão reflete a posição assentada do Órgão Especial do Tribunal de Justiça de São Paulo, que vem decidindo dessa forma para as leis semelhantes provenientes de outras cidades.

Tanto é assim que na Ação Direta de Inconstitucionalidade referente à proibição das sacolas no Município de São José do Rio Preto, o voto divergente do Desembargador Renato Nalini ${ }^{131}$ criticou a posição do Órgão Especial do Tribunal de Justiça do Estado de São Paulo:

"A regra neste Colegiado tem sido fulminar de inconstitucionalidade a quase totalidade de atos normativos produzidos pelo Parlamento local (...) Cabe indagar: quais interesses atenderia a extração da norma do ordenamento? Certamente não o interesse difuso e coletivo de todos os munícipes, hoje beneficiados pelo saudável protagonismo de seus legisladores".

\footnotetext{
${ }^{130}$ Reclamação n. 13818, Rel. Min. Ricardo Lewandowski, julgado em 22/05/2012.

${ }^{131}$ ADI no 0121455-49.2011.8.26.0000, Rel. Walter de Almeida Guilherme, órgão Especial do Tribunal de Justiça do Estado de São Paulo, julgamento em 23/11/2011.
} 
O posicionamento mais tradicional do Tribunal de Justiça de São Paulo, inclusive, estava em sincronia com a posição majoritária do Supremo Tribunal Federal até o ano de 2008. No entanto, naquele ano houve o julgamento da medida cautelar em Ação Direta de Inconstitucionalidade sobre o caso da proibição do amianto, que pode ser visto como um primeiro importante precedente contra a prevalência das normas federais, o qual será posteriormente analisado.

Diante da suspensão da eficácia da lei, a Associação Paulista de Supermercados (APAS) acabou por assinar um acordo com cerca de $90 \%$ dos supermercados do Estado de São Paulo, com o fim de que estes parassem de distribuir as sacolas plásticas em seus estabelecimentos. O início da vigência deste ajuste estava previsto para o dia 25 de janeiro de 2012, em comemoração ao aniversário da capital do Estado.

No entanto, diante da insuficiente publicidade do acordo e do conseqüente despreparo dos consumidores para se adequarem à nova medida, o PROCON e o Ministério Público do Estado de São Paulo firmaram um Compromisso de Ajustamento de Conduta (TAC) com a APAS, para que os supermercados continuassem a fornecer as sacolas plásticas gratuitamente por mais 60 (sessenta) dias. Nesse período, deveriam os estabelecimentos informar aos consumidores, previa e ostensivamente, que não mais seriam fornecidas as sacolas descartáveis.

Referido TAC, por sua vez, acabou por não ser homologado pelo Conselho Superior do Ministério Público (CSMP). O Procurador de Justiça Mário Antônio de Campos Tebet, relator do caso, entendeu que haveria uma desvantagem exagerada para o consumidor, pois o compromisso "não observa o equilíbrio que deve existir entre fornecedor e consumidor, no mercado de consumo, impondo somente ao consumidor o ônus de ter que arcar com a proteção do meio ambiente, já que terá que pagar pela compra de sacolas reutilizáveis, nenhum ônus atribuindo-se ao fornecedor" ${ }^{132}$.

Logo após o indeferimento da homologação do TAC, o retorno das sacolas foi determinado por decisão liminar em Ação Civil Pública movida pela Associação Civil SOS Consumidor perante a $1^{\circ}$ Vara do Fórum João Mendes Jr, processo

132 Autos no 14.0161.0000981/2011 - Promoção de Arquivamento com Termo de Compromisso de Ajustamento de Conduta 
n. 0155391-22.2012.8.26.0100 ${ }^{133}$. Com esta decisão, os supermercados foram obrigados a voltar a fornecer as sacolas plásticas, após alguns meses de suspensão.

Posteriormente, em recurso de Agravo de Instrumento (AI n. 0165606-66.2012.8.26.0000) contra esta liminar, os supermercados conseguiram cassá-la, obtendo a possibilidade de voltar a suspender o fornecimento, em decisão proferida pelo Desembargador relator Torres de Carvalho:

"Inexiste lei a compelir as rés ao fornecimento das sacolas plásticas ou das sacolas biodegradáveis; a suspensão do fornecimento se insere em um contexto mais amplo de proteção ao meio ambiente, obrigação também dos fornecedores; e que o fornecimento gratuito faz com que os consumidores que trazem suas sacolas paguem pelas sacolas dos demais, sendo assim prejudicados e não beneficiados".

Entretanto, após toda a celeuma causada, em que pese o provimento jurisdicional favorável, os supermercados preferiram continuar com a distribuição das sacolas, sendo certo que neste caso a decisão política prevaleceu sobre a jurídica. Isto porque a pressão dos meios de comunicação contra o fim das sacolas, notadamente nas rádios, incitou parcela da população não só a exigi-las como a parar de frequentar os estabelecimentos que não as estivessem distribuindo.

Algumas cidades do interior paulista buscaram até mesmo produzir leis que obrigassem os estabelecimentos comerciais a fornecerem sacolas gratuitamente aos consumidores.

O Município de Franca foi o primeiro a aprovar referida norma (Lei $\mathrm{n}^{\mathrm{o}}$ 7.649/2012), posteriormente seguido por outros que tiveram a mesma iniciativa (como Votuporanga, São José do Rio Preto entre outras). No entanto, estas leis também têm sido declaradas inconstitucionais, pois, segundo o entendimento atualmente dominante do Órgão Especial do Tribunal de Justiça de São Paulo, os Municípios não detêm competência legislativa para tais normas (por exemplo: ADI n. 0102921-23.2012.8.26.0000134 suspendeu a lei de Franca; ADI n. 0177237-07.2012.8.26.0000 ${ }^{135}$ suspendeu a lei de

\footnotetext{
133 Ação Civil Pública - processo n. 0155391-22.2012.8.26.0100, $1^{\text {o }}$ Vara Central da capital, julgado em 25/06/2011.

${ }^{134}$ ADI n. 0102921-23.2012.8.26.0000, Rel. Desembargador Walter De Almeida Guilherme, Órgão Especial do Tribunal de Justiça de São Paulo, julgado em 15/05/2013.

135 ADI n. 0177237-07.2012.8.26.0000, Rel. Desembargador Paulo Dimas Mascaretti, Órgão Especial do Tribunal de Justiça de São Paulo, julgado em 30/01/2013.
} 
Votuporanga e a ADI n. 0070431-45.2012.8.26.0000 ${ }^{136}$ suspendeu a de São José do Rio Preto).

Apesar da celeuma instaurada em todo o Estado, não é a pretensão desta dissertação discutir os argumentos pró e contra a distribuição das sacolas ou mesmo o acordo celebrado pela APAS, menos ainda os demais questionamentos levantados pela mídia, a exemplo do suposto enriquecimento dos donos dos supermercados que incluíam os custos das sacolas nos preços dos produtos.

Todavia, fato que nos parece relevante é o de que após a suspensão da eficácia da lei paulistana proibitiva das sacolas pelo Tribunal de Justiça do Estado de São Paulo, a suspensão da distribuição restou amparada num simples acordo, que carecia de força jurídico-coercitiva. E diante desta precariedade, poucos meses após a paralisação da distribuição, os supermercados voltaram a distribuí-las gratuitamente.

Nesse contexto, de maior relevância nos parece o estudo das competências constitucionais para avaliar a possibilidade dos Municípios editarem leis proibindo a distribuição de sacolas plásticas, como feito não só em algumas cidades do Estado de São Paulo, mas também em outros inúmeros Municípios e até em alguns Estados. Representando os primeiros, tem-se como exemplo as cidades de Belo Horizonte, Curitiba, Sorocaba, Londrina, Santos, Jundiaí, Teresina, Guarulhos etc., e, quanto aos segundos, podem ser citar os Estados de Goiás, Espírito Santo, Maranhão, Rio de Janeiro, Rio Grande do Norte etc.

Para tentar solucionar este questionamento, importante se faz a análise dos argumentos lançados em algumas das ações diretas de inconstitucionalidades sobre a distribuição das competências legislativas na Constituição Federal, mormente àquelas relacionadas aos temas de proteção do meio ambiente.

No Espírito Santo, a Lei n. 8.745/2007 obriga os estabelecimentos comerciais do Estado a utilizarem, para o acondicionamento de produtos, embalagens plásticas oxi-biodegradáveis, mas acabou questionada via Ação Direta de Inconstitucionalidade n. 4431 no Supremo Tribunal Federal pela Associação Brasileira da Indústria de Material Plástico (ABIPLAST).

\footnotetext{
${ }^{136}$ ADI n. 0070431-45.2012.8.26.0000, Rel. Desembargador Guerrieri Rezende, Órgão Especial do Tribunal de Justiça de São Paulo, julgado em: 15/05/2013.
} 
Neste caso, apesar de ainda pendente de julgamento, importante consignar que já há parecer do então Procurador Geral da República (PGR), Roberto Gurgel, pela constitucionalidade da norma estadual. Segundo o PGR, referida lei "vem ao encontro das exigências constitucionais de proteção ao meio ambiente", de forma que haveria "razoável consenso quanto ao fato de que as normas federais fixam patamares mínimos de proteção ambiental, o que não exclui a possibilidade de os demais entes federados estipularem condições mais rígidas as normas federais".

Já a Ação Direta de Inconstitucionalidade n. 4483 no Supremo Tribunal Federal contra a Lei Estadual 5.502/2009 do Rio de Janeiro, questiona o dispositivo que obriga os estabelecimentos comerciais a recolher e substituir sacolas e sacos plásticos usados como embalagem dos produtos.

Nesta ADI (n. 4483) ajuizada pela Confederação Nacional do Comércio de Bens, Serviços e Turismo (CNC) o principal argumento é de que a competência para legislar sobre a proteção do meio ambiente seria somente da União. $\mathrm{O}$ caso tem como relator o Ministro Celso de Mello e atualmente está pendente de julgamento.

Em que pesem não serem especificamente leis municipais, esses dois primeiros exemplos são interessantes na medida em que a discussão sobre a competência legislativa é muito semelhante. Se não bastasse, inúmeras cidades vêm editando leis no mesmo sentido, que suscitaram as mesmas dúvidas e as correspondentes ações de inconstitucionalidades.

Pode-se recordar a lei de Teresina (Lei n. 3.874/09), que proíbe a utilização de sacolas plásticas em estabelecimentos comerciais, aceitando tão somente as biodegradáveis, assim como a previsão do uso de saco de lixo ecológico pelo Município de Belo Horizonte, em razão da Lei municipal 9.529/08.

Já no que toca às leis municipais do Estado de São Paulo, o Tribunal de Justiça as vem suspendendo. Em Guarulhos, a Lei Municipal no 6481/09 previa o uso de sacolas de plástico biodegradáveis, oxi-biodegradáveis ou retornáveis nos estabelecimentos comerciais, mas acabou suspensa por decisão do Desembargador Maurício Vidigal na Ação Direta de Inconstitucionalidade n 994.09.228314-7. 
O mesmo destino se deu à Lei Municipal n. 4.873/09 de Caçapava e a Lei Complementar 233/08 de Piracicaba, ambas suspensas por preverem a substituição das sacolas plásticas por oxi-biodegradáveis ou biodegradáveis.

$\mathrm{Na}$ cidade de Campinas, a Lei Municipal $\mathrm{n}^{\circ} 14.383$, de 12 de setembro de 2012, também buscou abolir as sacolas de plástico comum, impondo a obrigatoriedade dos estabelecimentos comerciais utilizarem embalagens plásticas biodegradáveis ou reutilizáveis para o acondicionamento de produtos, mas também acabou julgada inconstitucional pela Ação Direta de Inconstitucionalidade n. 022471778.2012.8.26.0000 $0^{137}$.

Já na cidade de Jundiaí, também houve a suspensão de sua Lei n. 7.210/08, proibitiva das sacolas, por Ação Direta de Inconstitucionalidade (ADI n. 0230256-30.2009.8.26.0000 ${ }^{138}$ ). Recentemente houve interposição de Recurso Extraordinário, sendo admitido pelo Tribunal de Justiça de São Paulo, de modo que o recurso foi encaminhando ao Supremo Tribunal Federal.

Nesta Ação Direta de Inconstitucionalidade destacam-se alguns argumentos ofertados no parecer do Subprocurador-Geral de Justiça do Ministério Público, Dr. Sérgio Turra Sobrane. Asseverou o membro do Parquet que:

"considerando que o direito é uno e considerando que os princípios constitucionais devem ser interpretados, aplicados e harmonizados sem prevalência de uns em detrimento de outros, não há como negar que o Município de Jundiaí, através dos seus representantes eleitos, no caso sob análise, tem competência na matéria”.

Assim, a lei municipal não estaria invadindo a esfera de competência exclusiva do Estado ou da União, mas apenas traçando os contornos para a execução de uma atividade lucrativa que deteriora o meio ambiente. Logo, concluiu pela constitucionalidade de referida lei municipal.

Em que pese a procedência da Ação Direta de Inconstitucionalidade, o Município de Jundiaí acabou por realizar um acordo no mesmo sentido da lei suspensa. Assim, a suspensão da distribuição das sacolas somente se deu após a iniciativa de uma

137 ADI n. 0224717-78.2012.8.26.0000, Rel. Desembargador Antonio Carlos Malheiros, Órgão Especial do Tribunal de Justiça de São Paulo, julgado em: 27/03/2013.

${ }_{138}$ ADI n. 0230256-30.2009.8.26.0000, Re. Desembargador José Roberto Bedran, Órgão Especial do Tribunal de Justiça de São Paulo, julgado em 03/02/2011 
parceria entre os comerciantes e a prefeitura. No caso, passaram a vender sacolas biodegradáveis (a preço de custo - $\mathrm{R} \$ 0,19$ ) e grandes cestas de plástico com capacidade de 12 quilos. Referido acordo busca que os consumidores evitem o uso excessivo, bem como que se acostumem a levar sacolas de casa.

Pacto semelhante foi o realizado pelos supermercados da cidade de Descalvado. Neste caso, eles deixaram de distribuir as sacolas plásticas por acordo realizado com a Promotoria do Meio Ambiente local.

Tais atitudes estão em consonância com iniciativas de outros países, como a Alemanha e a Argentina, na qual as sacolas já são cobradas. Na campanha "Saco é um Saco"139 do Ministério do Meio Ambiente, verifica-se que na Irlanda os clientes pagam pelas sacolas desde 2002 e a conseqüência foi uma redução de $97 \%$ no consumo. Na China o governo proibiu a distribuição gratuita de sacolas desde 2008. Na cidade do México a nova lei de resíduos também estabelece a cobrança pelas sacolas plásticas, estimando diminuir o consumo em milhões de unidades diárias.

Tratando mais especificamente das ações diretas de inconstitucionalidades de leis municipais paulistas que foram apreciadas pelo Tribunal de Justiça do Estado de São Paulo, um dos casos que mais acendeu o debate foi o da ação contra a lei proibitiva de São Jose do Rio Preto.

O Órgão Especial, na Ação Direta de Inconstitucionalidade $n$ 0121455-49.2011.8.26.0000 ${ }^{140}$, por maioria de votos, declarou a inconstitucionalidade de referida norma, na esteira do voto do Desembargador relator.

O Desembargador relator, Walter de Almeida Guilherme, entendeu que a Constituição Federal outorgou aos Municípios a competência administrativa comum, mas a competência legislativa concorrente fora distribuída somente para os demais entes, com exclusão dos Municípios. Assim, somente poderia o Município legislar ambientalmente suplementando a lei federal estadual no que couber, o que não teria sido o caso.

Referida posição foi seguida pelo voto vencedor do Desembargador José Roberto Bedran, no qual entendeu que o interesse ultrapassava os limites do Município, afastando sua competência legislativa.

\footnotetext{
${ }^{139}$ http://www.sacoeumsaco.com.br/

${ }^{140}$ ADI n 0121455-49.2011.8.26.0000, Desembargador Rel. Walter de Almeida Guilherme, Órgão Especial do Tribunal de Justiça de São Paulo, julgado em 23/11/2011.
} 
No caso, afirmou que o interesse da preservação do meio ambiente não poderia ser considerado como predominante do âmbito local: "Trata-se, na verdade, de assunto de concorrente interesse regional e nacional, conforme deixou claro a própria Lei Maior ao enquadrar a matéria na competência legislativa concorrente da União, Estados e Distrito Federal (art. 24, VI, da CF/88)"'.

Nessa linha de raciocínio, argumentou que "embora louváveis os bons propósitos da lei, a degradação ambiental é objeto de preocupação nacional”, sendo certo que a norma impugnada violaria os princípios federativos e da repartição de competências.

Por outro lado, no acórdão também constou a declaração de dois votos vencidos. O primeiro, do Desembargador Renato Nalini, iniciou-se com a citação da doutrina de Paulo Bonavides: "A conformidade da lei com a Constituição não consiste apenas em verificar formalmente se a Lei está de acordo com a regra suprema, mas em determinar também a compatibilidade material (BONAVIDES, Paulo. Curso de Direito Constitucional. 9a ed. São Paulo: Malheiros Editores, 2000, p. 478)”.

A partir desta citação, recordou que o Município é ente da Federação, diversamente do que ocorre na maioria das Federações do mundo. Assim, a "rigidez da análise das atribuições torna o Legislativo Municipal mero homologador", de forma que "A constatação é a de que de nada valeu - ou foi resultado de mero exercício retórico - a inclusão do Município como entidade da Federação a partir de 1988."

Já no voto do Desembargador Roberto Mac Cracken, restou consignado que não haveria inconstitucionalidade de norma que vem atender a proteção ao meio ambiente sustentável, pois a postura contrária é que afrontaria o princípio da proibição do retrocesso ecológico.

Dessa forma, afirmou que "o Poder Constituinte Originário impôs combinação de esforços dos entes federativos para aumentar a tutela dos interesses arrolados no supra mencionado dispositivo constitucional, dentre eles, o meio ambiente".

Finalizando, ressaltou que não houve invasão da competência concorrente, até porque não há na norma impugnada uma norma geral a respeito de proteção ambiental, mas uma matéria específica: o descarte e utilização de sacolas plásticas por entidades empresariais. 
Como foi vencedora a tese da inconstitucionalidade da lei do Município de São José do Rio Preto, houve a interposição de Recurso Extraordinário no Supremo Tribunal Federal.

Em que pese ainda não ter havido julgamento do recurso, já há parecer parcialmente favorável à sua admissibilidade pela Procuradoria Geral de Justiça, o qual aduz que o caso tem evidente repercussão geral, com relevo social, político, jurídico, bem como que teria havido o prequestionamento necessário.

No caso da Ação Direta de Inconstitucionalidade n. 030296070.2011.8.26.0000 ${ }^{141}$, que contesta a Lei Municipal n. 2.315/09 de Hortolândia, o parecer da mesma Procuradoria Geral de Justiça foi ainda mais enfático: "Não há qualquer espaço para dúvida quanto ao fato de que o Município também tem competência administrativa e legislativa para fins de promover a defesa do meio ambiente, bem como zelar pela saúde dos munícipes."

Outro caso que merece ser brevemente analisado é o da Ação Direta de Inconstitucionalidade n. 0121470-18.2011.8.26.0000 ${ }^{142}$, do Município de Barueri, visando à suspensão da eficácia da Lei Municipal $n^{\circ}$ 1.863/09 que determinava aos estabelecimentos comerciais do Município que utilizassem embalagens biodegradáveis e/ou retornáveis para o acondicionamento de produtos.

O Desembargador José Robero Bedran, relator do caso, entendeu que a norma impugnada padecia de inconstitucionalidade por quebra do pacto federativo, pois não havendo interesse peculiar do Município, a norma invadiria a competência legislativa da União e do Estado. Além disso, asseverou:

“a medida preconizada na Lei Municipal é considerada até mesmo contrária ao meio ambiente pois 'no fim do processo de degradação, independentemente do tipo de plástico degradável, teremos subprodutos tóxicos e gases de efeito estufa. Assim, tais plásticos, vendidos como biodegradáveis, podem propiciar a deposição inadequada., em detrimento de seguir a cadeia de resíduos (minimização - consumo segregação - reuso ou reciclagem - disposição final)"'.

${ }^{141}$ ADI n. 0302960-70.2011.8.26.0000, Rel. Desembargador Kioitsi Chicuta, Órgão Especial do Tribunal de Justiça de São Paulo, julgado em 17/10/2012.

${ }_{142}$ ADI n. 0121470-18.2011.8.26.0000, Rel. Desembargador José Roberto Bedran, Órgão Especial do Tribunal de Justiça de São Paulo, julgado em 23/11/2011. 
Também afirmou que a insuficiência de estudos sobre a segurança das sacolas oxi-biodegradáveis ou biodegradáveis impediriam a manutenção da lei municipal, pois conflitaria com a política de reciclagem desenvolvida no Estado.

Por fim, com relação à admissibilidade da ação, ressaltou que as normas da Constituição Estadual, ao prever normas remissivas à Constituição Federal, muitas vezes mantêm sua condição de proposições jurídicas, sendo possível que sejam parâmetro normativo idôneo para o controle abstrato perante o Tribunal local.

Já no voto vencido do Desembargador Mário Devienne Ferraz constou que também competiria ao Município dispor sobre a preservação e proteção do meio ambiente:

"inegavelmente se insere a atividade de disciplinar a substituição das sacolas e sacos plásticos convencionais utilizados em estabelecimentos comerciais localizados em seu território, por embalagens biodegradáveis ou retornáveis, mormente por ser incontestável a potencialidade danosa ao meio ambiente do material que se pretender substituir."

Asseverou, ainda, que não teria havido norma de matéria geral de proteção ambiental -a qual deveria ficar a cargo do Estado - mas na verdade houve uma regulação específica de “descarte e utilização de sacolas plásticas por entidades empresarias, de modo que não houve ingresso em matéria legislativa reservada ao outro ente da federação."

Portanto, a conclusão que chegou o Desembargador foi a de que a norma impugnada somente buscou a melhoria da qualidade ambiental, o bem estar comum em seu território, proibindo as sacolas convencionais que são sabidamente danosas ao meio ambiente. Assim, “envolvendo a questão a proteção ambiental, é certo que a melhor solução deve mesmo ser aquela que privilegia a efetividade máxima à preservação do meio ambiente"

Em suma, referido embate verificado no Tribunal de Justiça paulista deverá ser em breve solucionado pelo Supremo Tribunal Federal, pois atualmente já existem vários casos com Recursos Extraordinários pendentes de julgamento. Eventual decisão pelo órgão de cúpula do Judiciário certamente influenciará, e muito, as futuras decisões dos Tribunais de Justiças locais. 


\subsection{A proibição da utilização do amianto crisotila}

Neste subtópico será analisado como o Supremo Tribunal Federal (STF) tem se posicionado sobre a competência concorrente dos Estados para legislar em matéria ambiental, especificamente sobre o caso do amianto crisotila.

A utilização do amianto tem gerado muita polêmica há anos, e envolve não só o Direito Ambiental, mas também trata de direito comercial, da saúde pública e do direito do trabalhador. Há cerca de uma década, inclusive, o Conselho de Auto Regulamentação Publicitária (CONAR) acabou por suspender as campanhas publicitárias que estavam sendo feitas a favor do uso do amianto.

Antes de entrar na análise do caso concreto propriamente dito, cumpre explicar que há inúmeras variedades de amianto ou asbesto, dentre as quais se destaca a crisotila ou "amianto branco".

Sua utilização comercial está relacionada, geralmente, às telhas, placas de revestimento, cimento, caixas d'água, filtros e até mesmo à indústria têxtil. Ocorre que, após sua larga utilização mundial, verificou-se que sua presença no ar causava sérios prejuízos aos seres vivos, especialmente aos seres humanos, trazendo-lhes graves doenças.

Assim, a primeira medida a ser tomada foi o controle rígido da utilização do amianto, inclusive com respaldo da Organização Mundial do Comércio (OMC), que autorizou a suspensão da importação de amianto pelos seus países membros.

Desde então, tem se buscado a substituição do amianto por outros produtos. Nesse sentido, em razão da importância do material para a indústria, Paulo de Bessa Antunes se mostra preocupado com a proibição total e imediata do mesmo: "é necessário que sejam estabelecidos mecanismos capazes de assegurar, se for o caso, a substituição do produto de forma gradativa, de modo que os impactos sobre a atividade econômica não gerem externalidades piores do que as que se deseja combater"143.

No Brasil, a Lei $\mathrm{n}^{\circ}$ 9.055, de 19 de junho de $1995^{144}$, complementada pelo Dec. $\mathrm{n}^{\mathrm{o}} 2.350 / 97^{145}$, vedou em todo território nacional a utilização do asbesto marrom,

\footnotetext{
143 ANTUNES, Paulo de Bessa. Op. cit. p. 200/201.
}

${ }^{144}$ Art. $1^{\circ}$ É vedada em todo o território nacional: 
amianto azul, bem como proibiu a pulverização de todos os tipos de fibras, tanto de asbesto/amianto da variedade crisotila como daquelas naturais e artificiais. Por outro lado, a lei admitiu o uso controlado da variedade "crisotila" (asbesto branco). Assim, em que pese referida lei ter proibido grande parte das variedades minerais do amianto, ela autorizou expressamente o uso da espécie "crisotila" em todo o território nacional ${ }^{146}$.

Buscando evitar maiores danos aos trabalhadores, a mesma lei previu a necessidade do envio de uma avaliação médica periódica de cada um ao SUS Sistema Único de Saúde - para todas as empresas que utilizarem o amianto em suas atividades (artigo $5^{\circ}$ e parágrafo único da Lei $\mathrm{n}^{\circ}$ 9.055/95).

Contrariando em parte referida Lei Federal, o Estado do Mato Grosso do Sul editou a Lei Estadual $n^{\circ}$ 2.210/2001, proibindo integralmente a utilização do amianto em seu território. Tão logo foi editada, o Governador do Estado de Goiás (Estado este que contém a maior jazida de amianto no Brasil) ajuizou a Ação Direta de Inconstitucionalidade (ADI) contra referida norma. Houve liminar para suspender os efeitos da norma estadual sob o argumento de que o ente federativo não poderia violar a regra geral já estabelecida em lei federal.

Assim, num primeiro momento o Supremo Tribunal Federal decidiu que, havendo a lei federal, os Estados só poderiam suplementá-la, mas não contrariar suas regras. Desse modo, em razão da lei federal admitir o uso do amianto, teoricamente, leis estaduais ou municipais não poderia proibi-lo.

Apesar deste entendimento, o legislador paulista foi insistente e editou a Lei $n^{o}$ 12.684/07, que "proíbe o uso, no Estado de São Paulo, de produtos, materiais ou artefatos que contenham quaisquer tipos de amianto ou asbesto".

A partir dela, a proibição do amianto no Estado de São Paulo passou a ser um dos casos mais interessantes no qual o Supremo Tribunal Federal discutiu a

I - a extração, produção, industrialização, utilização e comercialização da actinolita, amosita (asbesto marrom), antofilita, crocidolita (amianto azul) e da tremolita, variedades minerais pertencentes ao grupo dos anfibólios, bem como dos produtos que contenham estas substâncias minerais;

II - a pulverização (spray) de todos os tipos de fibras, tanto de asbesto/amianto da variedade crisotila como daquelas naturais e artificiais referidas no art. $2^{\circ}$ desta Lei;

III - a venda a granel de fibras em pó, tanto de asbesto/amianto da variedade crisotila como daquelas naturais e artificiais referidas no art. $2^{\circ}$ desta Lei.

${ }^{145}$ Art. $1^{\circ}$ A extração, a industrialização, a utilização, a comercialização e o transporte de asbesto/amianto, no território nacional, ficam limitados à variedade crisotila.

${ }^{146}$ Art. $2^{\circ} \mathrm{O}$ asbesto/amianto da variedade crisotila (asbesto branco), do grupo dos minerais das serpentinas, e as demais fibras, naturais e artificiais de qualquer origem, utilizadas para o mesmo fim, serão extraídas, industrializadas, utilizadas e comercializadas em consonância com as disposições desta Lei. 
competência da União e dos Estados, especialmente no que tange à possibilidade de legislação ambiental mais restritiva feita pelo ente federativo menor.

Apesar de não tratar especificamente da competência Municipal, este caso é muito significativo para demonstrar os argumentos utilizados pelos Ministros do STF a respeito da repartição de competências. Conforme será visto, grande parte da argumentação também pode ser utilizada perfeitamente aos conflitos que envolvam leis municipais.

Cumpre lembrar que o Supremo ainda não proferiu o julgamento definitivo da Ação Direta de Inconstitucionalidade que contesta referida Lei do Estado de São Paulo. No entanto, já houve o julgamento, pelo Plenário, da respectiva Medida Cautelar (MC em ADI n 3.937-7 SP).

Nesta Medida Cautelar, o Ministro Marco Aurélio votou pela concessão da liminar para suspender a eficácia da lei em questão. A Ministra Ellen Gracie, igualmente, proferiu seu voto no sentido de que a Lei Estadual impugnada contrariava norma geral da União, de modo que estaria extrapolando a competência complementar do Estado.

Segundo a magistrada, referida Lei Estadual deveria se restringir ao preenchimento de lacunas deixadas pela legislação federal, mas não poderia dispor de modo diametralmente oposta a esta. Assim, concluiu que, por já existir legislação federal sobre o amianto, haveria vício formal por invasão de competência legislativa da União, uma vez que a Lei Estadual estaria nulificando os efeitos da norma expedida pelo ente superior.

Desse modo, entendeu haver vício de inconstitucionalidade formal, em razão de usurpação de competências legislativas da União, assim como afronta ao pacto federativo e ao Estado Democrático de Direito.

Lembrou também que nas ADIs no 2.656-9/SP e 2.396-9/MS o STF entendeu não caber ao Estado legislar sobre o amianto, especialmente porque já existiria legislação federal sobre a matéria, de forma que a legislação estadual não poderia buscar tornar nulos os efeitos da norma do ente federativo de superior hierarquia.

Outros argumentos utilizados foram no sentido de que o Estado de São Paulo teria usurpado a competência exclusiva da União estabelecida na Constituição Federal. Isto porque teria o Estado legislado sobre recursos minerais (matéria privativa da 
União - artigo 22, inciso XII, da CF), a pretexto de legislar sobre produção e consumo, meio ambiente e proteção à saúde pública (competência concorrente - artigo 24, incisos V, VI e XII).

Além disso, buscaram alicerçar-se em argumentos extrajurídicos, como o desemprego para os trabalhadores do setor, os inúmeros prejuízos para empresas que trabalham com o amianto, bem como a existência de índices suportáveis de tolerância humana ao amianto crisotila, sem contar que entenderam não haver interesse local a justificar a regulamentação em território estadual.

Além destes argumentos, a Ministra Ellen Gracie ainda consignou que o Supremo Tribunal Federal não poderia ser palco para discussão dos eventuais malefícios ambientais de atividades ou produtos, devendo a Corte se restringir à análise sobre a adequação das leis ao ordenamento pátrio. Por isso, afirmou que caberia à academia de ciência, e não ao STF, decidir sobre a nocividade de produtos.

Referido entendimento já havia sido explanado no julgamento da Medida Cautelas da Ação Direta de Inconstitucionalidade nº 2.396/03-MS:

"Não cabe a esta Corte dar a última palavra a respeito das propriedades técnico-científicas do elemento em questão e dos riscos de sua utilização para a saúde da população. (...) Competência do Supremo Tribunal Federal circunscrita à verificação da ocorrência de contraste inadmissível entre a lei em exame e o parâmetro constitucional”, ${ }^{, 147}$.

Os Ministros do Supremo que acompanharam o voto da Ministro Ellen Gracie também buscaram reforçar que as leis estaduais e municipais proibitivas do amianto estariam violando a regra geral da lei federal que o admite. Como exemplo, utilizaram os precedentes da ADI 2.396/03 MS, ADI 2.656/03 SP, ADI 3.356/05 PE, todas julgadas procedentes sob o argumento de que os entes federativos não poderiam violar a regra geral já estabelecida pela lei federal.

Até esse momento não haveria novidades no posicionamento do Supremo, pois até então os precedentes realmente declaravam a inconstitucionalidade das normas que contrariavam a legislação federal.

No entanto, o julgamento desta da Medida Cautelar referente ao amianto, pelo Plenário do Supremo Tribunal Federal, representou um marco na discussão

${ }^{147}$ ADI n. 2396 MC/MS, Rel. Min. Ellen Gracie, Tribunal Pleno, julgado em 26/09/2001. 
acerca da repartição de competência ambiental justamente porque os demais Ministros romperam com esta posição tradicional do Pretório Excelso. Assim, este caso é tratado como o primeiro grande precedente a contrariar o entendimento majoritário dos Tribunais do País, inclusive do próprio STF.

Da leitura do Acórdão publicado, verifica-se no voto vencedor do Ministro Eros Grau, uma mudança de seu entendimento anterior, pois em casos anteriores já havia compartilhado da tese até então dominante. Apesar disso, asseverou, com humildade, que preferiu rever seu posicionamento anterior por não mais considerá-lo correto, afirmando expressamente que teria errado antes e que, como ser humano, deveria reconhecer seu erro.

Referida mudança de posição se deu, entre outros motivos, por passar a entender que a própria norma permissiva do amianto (Lei 9.055/95) seria inconstitucional.

Além disso, também fundamentou seu voto divergente na correspondência da iniciativa estadual com a Convenção 162 da OIT $^{148}$ (Organização Internacional do Trabalho), a qual determina a substituição do amianto por outras alternativas tecnológicas sempre que viável, bem como recomenda a não pulverização do amianto. Referida Convenção, por ter sido incorporada ao ordenamento jurídico brasileiro antes da Emenda Constitucional $\mathrm{n}^{\circ} 45$, teria status de norma supralegal, conforme entendimento esposado pelo Supremo Tribunal Federal no julgamento do RE n. 349.073RS, relator. Ministro Carlos Ayres Britto. Em razão disso, tornaria inaplicável a legislação infraconstitucional com ela conflitante.

Outro motivo deveras relevante que motivou o Ministro Eros Grau a alterar seu entendimento foi a necessidade de fortalecimento do princípio constitucional do direito à saúde. Sendo a lei estadual paulista mais protetiva, estaria dando primazia à saúde sobre o livre comércio, o que, numa ponderação de valores, deveria mesmo prevalecer.

Saindo da análise técnica da competência sob o aspecto formal, o Ministro passou a sustentar que a inconstitucionalidade formal deveria ser analisada com muita prudência, especialmente porque a própria lei que autorizaria o amianto seria

\footnotetext{
${ }^{148}$ Aprovada pelo Congresso Nacional por meio do Decreto Legislativo ${ }^{\circ}$ 51, de 25 de agosto de 1989;
} Ratificada em 18 de maio de 1990; Promulgada pelo Decreto nº 126 de 22 de maio de 1991. 
inconstitucional por agredir o artigo 196 da Constituição Federal, que trata da proteção da Saúde.

Após a exposição desta linha de argumentação, foi acompanhado por vários Ministros. Joaquim Barbosa entendeu que a jurisprudência do STF era muito exigente quanto às limitações às leis estaduais sobre a circulação de bens e mercadorias.

Lewandowski, por sua vez, entendeu que "em matéria de meio ambiente e saúde pública nada impede que a legislação estadual ou municipal seja mais restritiva, e, portanto, mais protetiva, não havendo violação à competência concorrente"149 .

Os Ministros asseveraram que há doenças relacionadas ao amianto, que tal substância já pode ser substituída por outras e, assim, se um ente da Federação legislasse em nome da salvaguarda da saúde pública e do meio ambiente, multiplicando as cautelas em seu território, não poderia ser taxada de inconstitucional. Até porque tanto a União quanto os Estados detêm certa margem de discricionariedade para, dentro de limites razoáveis, atender aos interesses da comunidade.

A Ministro Carmem Lúcia, após instaurada a divergência, acabou por reajustar seu voto no sentido de acompanhar estes Ministros. Entendeu que o direito à saúde, não apenas seria de competência legislativa concorrente, mas também de competência material comum, de modo que autorizar a edição de uma lei que buscasse materializar esta proteção.

Nesse sentido, o Ministro Lewandowski acrescentou que o princípio federativo, juntamente com o princípio democrático e o princípio republicano, constitui um dos sustentáculos da Constituição Federal de 1988. Dessa forma, a competência legislativa concorrente para a proteção a saúde incluiria a possibilidade da competência dos Estados, não impedindo que a legislação estadual e a municipal sejam mais restritivas do que a federal.

Já o Ministro Carlos Ayres Britto, neste assunto, recordou que competiria à União a edição das normas gerais e aos Estados a suplementação. No caso, entendeu que a norma estadual estaria conforme a Constituição Federal em razão da proteção da saúde e de se evitar riscos ao meio ambiente. Estando em consonância aos

\footnotetext{
149 Pag. 1159 do Processo Eletrônico no STF - $\quad$ ADI 3937. http://redir.stf.jus.br/estfvisualizadorpub/jsp/consultarprocessoeletronico/ConsultarProcessoEletronico.jsf?seq objetoincidente=2544561 - Acesso em 19 de fevereiro de 2013.
} 
desígnios constitucionais, a norma garantiria maior eficácia aos direitos fundamentais estabelecidos na Carta Magna.

Já o Ministro Cezar Peluso concordou com a manifestação do Ministro Eros Grau de que na verdade a lei federal é que seria inconstitucional, ao passo que o Ministro Celso de Mello votou no mesmo sentido em razão da supremacia do princípio da proteção da saúde e do meio ambiente ecologicamente equilibrado, materializados nos artigos 196 e 225 da Constituição.

Diante dessas manifestações, os Ministros acabaram por realizar um julgamento antecipado da ADI $n^{\circ} 4.066$, na qual é contestada a própria Lei Federal $\mathrm{n}^{\mathrm{o}}$ 9.055/95, na medida em que muitos já declararam que ela seria inconstitucional. Caso esse entendimento prevaleça, o órgão de cúpula do Poder Judiciário estará corroborando que o amianto, em qualquer de suas formas, é prejudicial tanto à saúde pública, como ao meio ambiente saudável. Até o momento, no entanto, referida Ação Direta de Inconstitucionalidade não foi julgada definitivamente pelo Supremo.

Outra conclusão dos votos vencedores do julgamento da medida cautelar que pode ser extraída é que o Estado de São Paulo não invadiu competência legislativa da União, mas apenas legislou em prol do meio ambiente e da saúde pública.

Assim, perante a maioria dos Ministros, foi vencedora a tese já consagrada na doutrina ambientalista, de que a lei federal criaria um piso mínimo de proteção ao meio ambiente, reservando aos demais entes da Federação a possibilidade de criarem leis mais protetivas.

Referida decisão também parece estar em conformidade com o crescimento da conscientização sobre a necessidade de preservação do meio ambiente, da saúde pública em geral e dos trabalhadores em particular.

Como consequiência da tese vencedora, os Ministros acabaram por reflexamente responder às críticas de que os julgadores se atentavam tão somente aos aspectos formais da legislação sub judice, não levando em consideração o direito material que se busca tutelar por meio da norma.

E quando se trata do meio ambiente e da saúde da população, muitos advogam que não poderia um julgamento se ater tão somente aos tecnicismos jurídicos e esquecer-se dos bens jurídicos envolvidos. A repercussão geral da decisão no mundo fenomenológico se mostra tão importante quanto a própria discussão de repartição de 
competência envolvida no caso concreto, devendo ambas as questões ser analisadas conjuntamente. Reforça esta tese a realização de audiências públicas nas ADIs que discutem as leis que proíbem a queima da palha da cana-de-açúcar no Estado de São Paulo, pois caso não fosse necessária a análise do direito material envolvido, seriam de todo prescindíveis referidas consultas populares.

Diante de todo o exposto, o Supremo Tribunal Federal, por 7 votos a 3 (vencidos os Ministros Marco Aurélio, Menezes Direito e Ellen Gracie), expressamente manteve a constitucionalidade da Lei paulista $n^{\circ} 12.684 / 2007$ e, implicitamente reforçou que a suplementação da lei federal poderia ser mais restritiva a ponto de até proibir certas matérias ou substâncias que seriam prejudiciais à saúde da população e ao meio ambiente.

Em 2012, o Supremo Tribunal Federal realizou audiência pública sobre esta ação, demonstrando a relevância do caso para a sociedade. Após, em que pese tenha havido o início do julgamento, este acabou suspenso, de modo que até agora somente votaram os Ministros Marco Aurélio, pela procedência da ADI, e Ayres Brito, pela improcedência. Mesmo não havendo o término deste julgamento, percebe-se que, em razão do amplo debate já realizado quando da decisão da Medida Cautelar desta ADI, muito provavelmente será mantido o posicionamento pela constitucionalidade da lei proibitiva do amianto.

Finalmente, a importância deste caso se dá em razão de que agora pode-se vislumbrar uma nova hermenêutica a respeito da repartição de competências constitucionais, demonstrando a necessidade de uma revisão da lógica jurídicoargumentativa até então dominante. Como visto, foi prestigiado, pelo órgão supremo do Judiciário, um federalismo efetivo com ampla liberdade para todos os entes integrantes, de modo a abrir uma grande possibilidade do avanço na proteção ambiental do País. O novo entendimento prestigia a autonomia legislativa dos Estados e Municípios, os quais poderão editar leis mais protetivas visando à promoção do bem de todos, da saúde pública e do meio ambiente ecologicamente equilibrado.

Diante da ruptura de paradigma criado no julgamento desta medida cautelar, se mostra deveras importante o acompanhamento da agenda do Supremo Tribunal Federal para verificar quando se dará o julgamento do mérito final deste caso, sem falar da necessidade da verificação de outros casos que também discutam a repartição de competências e também estão aguardando para entrar na pauta de julgamento. 


\subsection{Lei da Cidade Limpa}

Outro exemplo que se pode citar quanto à competência municipal para edição de leis que visam tutelar o meio ambiente de modo mais abrangente -intensificando a proteção - é a Lei n ${ }^{\circ}$ 14.223, de 26 de setembro de 2006, do Município de São Paulo, que instituiu o "Programa Cidade Limpa".

A exposição de motivos do Projeto de Lei 379/2006, que culminou na edição da Lei 14.223, de autoria de Gilberto Kassab, então Prefeito do Município de São Paulo, dispunha que o objetivo da norma seria:

“estabelecer nova disciplina legal dotada de instrumentos que assegurem maior equilíbrio e harmonia entre os interesses públicos e privados na utilização do espaço urbano, impedindo a ocupação desordenada, especialmente pela veiculação de anúncios, que têm maculado paisagem do Município de São Paulo, concorrendo para a notória poluição visual da cidade, uma das maiores do mundo".

A mencionada lei, portanto, determinou novas regras - mais rígidas que as anteriormente existentes - para a utilização das superfícies externas, tanto de espaços públicos, como de espaços privados, que eram muito utilizados, e ainda o são, em outras cidades, para a veiculação publicitária, por meio de outdoors, placas, dentre outros meios.

$\mathrm{O}$ artigo $2^{\circ}$ da lei explicita o que se entende por "paisagem urbana", de modo que não se gere dúvida quanto à amplitude e alcance dos dispositivos nela previstos. O mencionado artigo, como se pode observar, traz definição suficientemente abrangente do termo, possibilitando assim a efetiva proteção do meio ambiente artificial:

“Art. $2^{\circ}$ - Para fins de aplicação desta lei, considera-se paisagem urbana o espaço aéreo e a superfície externa de qualquer elemento natural ou construído, tais como água, fauna, flora, construções, edifícios, anteparos, superfícies aparentes de equipamentos de infra-estrutura, de segurança e de veículos automotores, anúncios de qualquer natureza, elementos de sinalização urbana, equipamentos de informação e comodidade pública e logradouros 
públicos, visíveis por qualquer observador situado em áreas de uso comum do povo."

Percebe-se, assim, que a lei tornou mais rigorosas as regras para a veiculação de publicidade em superfícies externas. Não objetiva a lei, entretanto, afetar o exercício da atividade publicitária, mas sim melhorar o meio ambiente da cidade, também denominado de meio ambiente artificial. $\mathrm{O}$ artigo $3^{\circ}$ da Lei dispõe, neste sentido, que:

"Art. $3^{\circ}$ - Constituem objetivos da ordenação da paisagem do Município de São Paulo o atendimento ao interesse público em consonância com os direitos fundamentais da pessoa humana e as necessidades de conforto ambiental, com a melhoria da qualidade de vida urbana (...)"

Assim, embora tenha sido afetada por consequência dessa norma, a lei não visou prejudicar ou restringir a atividade comercial e publicitária. Na verdade, tão somente regulou, de forma rígida, um dos muitos meios pelos quais se pode veicular publicidades, uma vez que tal veiculação pode ser danosa ao meio ambiente artificial, notadamente à paisagem urbana.

Apesar disso, logo após a promulgação da lei, muitas ações ordinárias ingressaram no Poder Judiciário, com pedidos de declaração de inconstitucionalidade incidental da Lei ${ }^{\circ}$ 14.223/06. Do mesmo modo, houve muitas ações com pedidos de condenação do Município para indenizar particulares, por "proibir atividade comercial", dentre outras alegações, que não se sustentaram juridicamente.

A $3^{\text {a }}$ Câmara de Direito Público do Tribunal de Justiça de São Paulo suscitou incidente de inconstitucionalidade $\mathrm{n}^{\circ}$ 163.152-0/3-00, referente a alguns artigos da Lei nº 14.223 de 2006, sendo requerida a Prefeitura Municipal de São Paulo.

O Órgão Especial do Tribunal de Justiça decidiu pela improcedência do referido incidente ${ }^{150}$, cuja ementa é:

"Constitucional - Incidente de inconstitucionalidade. Ausência de prejudicialidade em função do julgamento precedente, pelo Órgão Especial, de ADIn versando a mesma lei - Preliminar afastada. Arts. 9o, inciso III, X e XII; 17; 18; 21 e 44, parágrafo único, da Lei Municipal 14.223, de 26 de setembro de 2006, que regula "a ordenação dos elementos que compõem a paisagem urbana do Município de São Paulo"

150 ADI 1631520300 SP. Relator Ivan Sartori. Órgão Especial do TJ/SP. Julgado no dia 30/07/2008. Publicado no dia 22/08/2008. 
- Vício inexistente - Direitos à propriedade, ao exercício de atividade e à iniciativa privada preservados - Maltrato a direito adquirido e a ato jurídico perfeito descaracterizado - Limitações impostas ao particular que dizem com o interesse público - Competência legislativa do Município ocorrente - Inteligência dos arts. 23, VI; 30, I e VIII; e 182 da Carta Política - Precedentes do STF - Improcedência, rejeitada a preliminar (grifos nossos)."

O Relator do caso, Desembargador Ivan Sartori, esclareceu que as supostas inconstitucionalidades da lei não se justificavam, ressaltando que:

"Não se vislumbra, realmente, disparate constitucional a decorrer dos dispositivos legais em tela e mesmo do próprio diploma de que aqueles fazem parte, a ponto de concluir-se pela ausência de proporcionalidade e de razoabilidade.

Assim é que não impressiona o argumento de que seria exacerbada a restrição ou de que teria havido até vedação à modalidade publicitária por parte dessa normatização, considerados os alvos excluídos."

O Desembargador Relator destacou, ainda, que não haveria que se falar em restrição ao direito de propriedade. Justificou tal posicionamento embasando-se em decisão do Supremo Tribunal Federal em caso semelhante:

\section{“(...) ÔNUS DO PROPRIETÁRIO DE IMÓVEL URBANO.}

Instrumento próprio à política de desenvolvimento urbano, cuja execução incumbe ao Poder Público municipal, nos termos do disposto no artigo 182 da Constituição do Brasil Instrumento voltado à correção de distorções que o crescimento urbano desordenado acarreta, à promoção do pleno desenvolvimento das funções da cidade e a dar concreção ao princípio da função social da propriedade [art. 170, m da $\mathrm{CB}$. 4. Recurso extraordinário conhecido, mas não provido." (RE 387.047/SC, Pleno, Min. Eros Grau, DJ 02.05.08; Ement. Vol. 02317-04, pp. 00799)." (grifos nossos)

Percebe-se, assim, diante das considerações feitas pelo Relator, que a Lei do Município de São Paulo reflete uma política ambiental e urbanística, mas não uma tentativa de impedir a veiculação da publicidade ou uma ingerência no exercício de propriedade privada. E, deste modo, inegável que caberia ao Município editar leis desta 
natureza, cuja função é melhorar o meio ambiente urbano, propiciando melhor qualidade de vida à população da cidade.

Por fim, com relação à questão da competência do Município para a edição da referida lei, se não bastassem os comentários já realizados, que reflexamente já sustentavam a possibilidade da edição de leis mais protetivas ao meio ambiente pelo ente municipal, o Desembargador Ivan Sartori preferiu deixar ainda mais evidente que não haveria qualquer vício de competência para a edição da norma:

"Por conseguinte, agiu e age o Município em consonância com os arts. 30, incisos I e VIII, e 182 da Constituição Federal, não se cogitando, pois, de ofensa à iniciativa privada (art. $\mathrm{I}^{\circ}$, IV, e $170 \mathrm{da} C F$ ) ou ao direito de propriedade, máxime porque por forca de regra básica de hermenêutica, lei nenhuma, inclusive a Suprema, pode ser interpretada de modo conclui-se pela colidência de suas disposições, mas sim pela harmonia e consonância entre elas.

E, na espécie, reforça a concreção dessa harmonia o disposto no parágrafo único e no inciso VI do art. 170 da Lei Maior, os quais ressalvam o meio ambiente e disposição legal.

Por isso mesmo que não há falar em usurpação de competência legislativa exclusiva da União, tanto mais que o art. 23, inciso VI, da Carta Política atribui à União, Estados e Municípios competência concorrente para combater a poluição em qualquer de suas formas, inclusa a visual."'(grifos nossos)

Percebe-se, portanto, que, tanto em aspectos materiais, quanto em aspectos formais, a lei ora em análise não revela qualquer inconstitucionalidade. Quanto à questão da competência do Município para legislar sobre matéria ambiental (na qual se inclui a questão da poluição visual), como foi visto, o Relator deixou claro que se trata de competência concorrente, não havendo qualquer usurpação de competência exclusiva da União.

Assim, percebe-se que a Lei ${ }^{\circ} 14.223$ de 2006, conhecida como Lei da Cidade Limpa, é mais um caso em que se verificou o acatamento, pelo Tribunal de Justiça do Estado de São Paulo, da tese da possibilidade de o Município legislar em matéria ambiental, trazendo maiores restrições. 
Em síntese, vez mais foi aceita a constitucionalidade da lei municipal que amplia a proteção ambiental, seja relacionado ao meio ambiente natural, seja tratando mais do meio ambiente artificial. Assim, percebe-se que vem se consolidando a aceitação de uma legislação mais específica pelo ente local com vistas à melhoria da qualidade de vida de seus munícipes.

\subsection{Restrição ao consumo do tabaco}

Dentre as leis que tratam de saúde pública e reflexamente sobre o meio ambiente, poucas geraram tanta polêmica quanto a Lei $\mathrm{n}^{\circ}$ 13.541/2009 do Estado de São Paulo, conhecida como lei antifumo. A discussão sobre sua constitucionalidade não ocorreu apenas no meio jurídico, mas esteve presente também na pauta de jornais e revistas por muito tempo.

Os artigos $1^{\circ}$ a $4^{\circ}$ desta lei dispõem que:

"Artigo $1^{\circ}$ - Esta lei estabelece normas de proteção à saúde e de responsabilidade por dano ao consumidor, nos termos do artigo 24, incisos V, VIII e XII, da Constituição Federal, para criação de ambientes de uso coletivo livres de produtos fumígenos.

Artigo $2^{\circ}$ - Fica proibido no território do Estado de São Paulo, em ambientes de uso coletivo, públicos ou privados, o consumo de cigarros, cigarrilhas, charutos ou de qualquer outro produto fumígeno, derivado ou não do tabaco.

$\S 1^{\circ}$ - Aplica-se o disposto no "caput" deste artigo aos recintos de uso coletivo, total ou parcialmente fechados em qualquer dos seus lados por parede, divisória, teto ou telhado, ainda que provisórios, onde haja permanência ou circulação de pessoas.

$\S 2^{\circ}$ - Para os fins desta lei, a expressão "recintos de uso coletivo" compreende, dentre outros, os ambientes de trabalho, de estudo, de cultura, de culto religioso, de lazer, de esporte ou de entretenimento, áreas comuns de condomínios, casas de espetáculos, teatros, cinemas, bares, lanchonetes, boates, restaurantes, praças de alimentação, hotéis, pousadas, centros comerciais, bancos e similares, supermercados, açougues, padarias, farmácias e drogarias, repartições públicas, instituições de saúde, escolas, museus, bibliotecas, espaços de exposições, veículos públicos ou privados de transporte coletivo, viaturas oficiais de qualquer espécie e táxis.

$\S 3^{\circ}$ - Nos locais previstos nos parágrafos $1^{\circ}$ e $2^{\circ}$ deste artigo deverá ser afixado aviso da proibição, em pontos de ampla visibilidade, com indicação de telefone e endereço dos órgãos estaduais responsáveis pela vigilância sanitária e pela defesa do consumidor. 
Artigo $3^{\circ}-\mathrm{O}$ responsável pelos recintos de que trata esta lei deverá advertir os eventuais infratores sobre a proibição nela contida, bem como sobre a obrigatoriedade, caso persista na conduta coibida, de imediata retirada do local, se necessário mediante o auxílio de força policial.

Artigo $4^{\circ}$ - Tratando-se de fornecimento de produtos e serviços, o empresário deverá cuidar, proteger e vigiar para que no local de funcionamento de sua empresa não seja praticada infração ao disposto nesta lei.

Parágrafo único - $\mathrm{O}$ empresário omisso ficará sujeito às sanções previstas no artigo 56 da Lei federal n. ${ }^{\circ} 8.078$, de 11 de setembro de 1990 - Código de Defesa do Consumidor, aplicáveis na forma de seus artigos 57 a 60, sem prejuízo das sanções previstas na legislação sanitária."

Percebe-se assim, que esta lei estadual restringiu em diversos aspectos a liberdade de utilização de produtos fumígenos, derivados ou não do tabaco, em "recintos de uso coletivo" parcial ou totalmente fechados. No $\S 2^{\circ}$ do artigo $2^{\circ}$ está previsto um rol, claramente exemplificativo, de locais que devem ser considerados como "recintos de uso coletivo".

Prevê a lei, ainda, em seu artigo $2^{\circ}, \S 3^{\circ}$, a necessidade da colocação de um aviso sobre a proibição nos locais determinados. No artigo $3^{\circ}$, a lei impõe ao responsável pelo recinto que advirta os infratores e, não sendo interrompida a conduta proibida, que os retire do local, podendo requisitar o auxílio da força policial se necessário. E, em seu artigo $4^{\circ}$, trata da responsabilidade do empresário omisso quanto às infrações de que trata a lei.

Pode-se perceber, assim, que a referida lei impôs uma restrição à liberdade individual do fumante - quanto aos locais em que não se poderia mais fumar em prol da coletividade, tanto por questões de saúde pública, como ambientais.

A lei, como já se poderia esperar, é objeto de Ação Direta de Inconstitucionalidade, tendo sido noticiada pelo próprio Supremo Tribunal Federal:

“A Confederação Nacional do Turismo (CNTUR) ajuizou, no Supremo Tribunal Federal (STF), a Ação Direta de Inconstitucionalidade (ADI) 4249, requerendo, em caráter liminar, a suspensão temporária da eficácia da aplicabilidade da lei estadual no 13.541/2009, do estado de São Paulo, que proíbe o consumo de cigarros e derivados de fumo em geral em ambientes de uso coletivo, públicos ou privados, naquele estado. No mérito, pede a declaração de inconstitucionalidade da referida lei",151

${ }^{151}$ Disponível em: http://www.stf.jus.br/portal/cms/verNoticiaDetalhe.asp?idConteudo=109485 
Para a Confederação Nacional do Turismo (CNTUR), a mencionada lei haveria usurpado competência da União, prevista constitucionalmente, e ferido diversos princípios fundamentais (dentre os quais cita a liberdade e a livre iniciativa). Referida entidade afirmou que se trata de "norma cogente proibitiva que possui o condão de, muito além do que suplementar (o que seria lícito), derrogar uma legislação federal" ${ }^{\prime 152}$.

Mais uma vez, então, surge a questão da competência dos Estados e Municípios para legislar sobre temas cuja competência é concorrente à União, em que este ente deve tratar das disposições gerais e dos princípios e aqueles devem tratar das normas específicas, suplementares.

Referida Ação Direta de Inconstitucionalidade $n^{\circ} 4249$, de relatoria do ministro Celso de Mello, ainda não foi julgada. Porém, já há pareceres divergentes constantes nesta ADI: da Advocacia Geral da União - pela inconstitucionalidade - e do Ministério Público Federal - pela constitucionalidade da lei.

A Associação Brasileira de Gastronomia, Hospedagem e Turismo e a Federação Nacional de Hotéis, Restaurantes, Bares e Similares (FNHRBS), na condição de amicus curiae, também opinaram pela inconstitucionalidade da lei.

No parecer da AGU, especificamente, foi sustentado que a lei antifumo seria formalmente inconstitucional, por vício de competência:

“diante dos parágrafos do art. 24 da Constituição de 1988, conclui-se que a competência concorrente prevista no caput do citado artigo comporta a competência para a edição de normas gerais, atribuída à União, bem como as competências suplementar (também chamada de competência não-cumulativa) e supletiva (cumulativa), destinadas aos Estados e ao Distrito Federal. Esta última - supletiva - somente surge com a inexistência de normas gerais, situação em que poderá o Ente Federado exercer a competência legislativa plena, dispondo, inclusive, sobre normas gerais"

Data venia, não se pode concordar com tal posicionamento. Afirmar que a mera existência de uma norma geral por parte da União impede todos os outros entes federados de editar quaisquer normas a respeito do tema se mostra desarrazoado.

${ }^{152}$ Idem. 
Parece que a advocacia pública da União tratou de modo idêntico a competência supletiva com a suplementar. No entanto, somente a primeira é que só pode ser utilizada na ausência de normas gerais. Já a competência suplementar busca justamente ir além da norma geral, de modo que a existência desta - norma geral - não afasta a possibilidade de edição daquelas - suplementares - por parte dos entes federados. Aos Municípios e aos Estados cabe, portanto, editar leis suplementares que se enquadrem nas possibilidades criadas pela norma geral, advinda da legislação federal.

O parecer do Ministério Público Federal, como supramencionado, foi favorável à constitucionalidade da lei no 13.541/2009 do Estado de São Paulo. Além deste, a Associação de Controle do Tabagismo, Promoção da Saúde e dos Direitos Humanos (ACT), Associação Mundial Antitabagismo e Antialcoolismo (AMATA), Fundação Ary Frauzino para Pesquisa e Controle do Câncer, o Estado do Rio de Janeiro e Sociedade de Pneumologia e Tisiologia (SBPT), na condição de amicus curiae, também se manifestaram pela constitucionalidade da lei.

O Parquet, em seu parecer, cita parte do voto do Ministro Francisco Rezek, na Representação 1.153 (a respeito da proibição de agrotóxicos, mas cujos ensinamentos aplicam-se, igualmente, ao caso ora em análise):

"Seria flagrante despropósito, contudo, entender que as normas federais estabelecem limites máximos à proteção da saúde, quando, na realidade essas normas constituem um piso, a partir do qual cada Estado desdobrará, na conformidade de suas condições e interesses próprios, o patrimônio legislativo. Não como conceber possa a União, valendo-se da regra que permite estabelecer normas gerais de defesa e proteção da saúde, fixar limites a esse empenho protetivo -por ventura mais firme e algumas unidades federadas - em nome da salvaguarda de outros valores, de outros bens jurídicos que não a própria saúde. Assim, neste exato domínio, jamais poderia reputar-se ofensivo à Constituição a lei estadual que multiplicasse as cautelas e os métodos de defesa da saúde, salvo quando ofensiva a outra norma constitucional, concebida para preservar valor jurídico diverso." (grifos nossos)

Vale mencionar que o Parquet fundamentou sua posição, também, a partir de Tratados Internacionais incorporados ao ordenamento pátrio. Restou afirmado que a Convenção-Quadro para o Controle do Tabaco teria suspendido a eficácia da Lei Federal 9.294, por ser posterior a esta: 
"Consequentemente, a legislação estadual ora impugnada, à luz da Convenção-Quadro para o Controle do Tabaco, não ultrapassa qualquer norma de competência constitucional da União. Pelo contrário, está em pena sintonia com a citada Convenção, que é a atual norma federal que rege a matéria, cumprindo o comando do art. 24, XII, da Constituição".

Assim, em consonância com os argumentos apresentados pelo representante do Ministério Público, não há que se falar em inconstitucionalidade formal da Lei $n^{\circ}$ 13.541/2009 do Estado de São Paulo. Assim como nos outros exemplos analisados neste trabalho, a lei antifumo somente impõe uma regra que amplia a tutela aos direitos difusos e coletivos, protegendo os cidadãos.

\subsection{Taxa de preservação ambiental em cidade litorânea}

Outro caso que pode ser citado quanto à competência dos Municípios para legislar sobre questões ambientais refere-se às tentativas de proteção do meio ambiente do extenso litoral brasileiro. Como exemplo, a Lei ${ }^{\circ}$ 547/2007, do Município de Ilhabela, instituiu a Taxa de Preservação Ambiental - TPA, com vistas à proteção dos frágeis ecossistemas litorâneos.

Válido citar os primeiros artigos da mencionada lei:

“Art. $1^{\circ}$ - Fica instituída a TAXA DE PRESERVAÇÃO AMBIENTAL TPA, nos termos desta Lei, acrescentando-se no Título IV, Capítulo XIII - DA TAXA DE PRESERVAÇÃO AMBIENTAL - TPA, de que trata o Código Tributário Municipal Lei 156/2002.

Art. $\mathbf{2}^{\circ}$ - A TAXA DE PRESERVAÇÃO AMBIENTAL - TPA tem como fato gerador o exercício regular do poder de polícia municipal em matéria de proteção, preservação e conservação do meio ambiente no território do Município da Estância Balneária de Ilhabela, incidente sobre o trânsito de veículos utilizando infraestrutura física na sua jurisdição.

Art. $3^{\circ}$ - A TAXA DE PRESERVAÇÃO AMBIENTAL - TPA tem como base de cálculo o custo estimado da atividade administrativa em função da degradação e impacto ambiental causados pelos veículos em circulação no Município.

Art. $4^{\mathbf{0}}$ - A TAXA DE PRESERVAÇÃO AMBIENTAL - TPA será lançada e arrecadada na saída dos veículos do território do Município, no terminal das balsas, e que será operacionalizada pela Secretaria Municipal de Finanças conjuntamente com agente de trânsito, mediante a expedição de comprovante do pagamento nos seguintes valores: 
I - Para os veículos de pequeno porte (automóveis e motocicletas) - R $\$$ 2,00 (dois reais);

II - Para veículos utilitários (caminhonetes e Volkswagem Kombi) - R\$ 3,00 (três reais);

III - Para veículos de excursão - Vans - R\$ 100,00 (cem reais);

IV - Para microônibus - R \$ 200,00 (duzentos reais);

V - Para ônibus - R\$ 300,00 (trezentos reais).

Parágrafo Único - Os valores que tratam os incisos acima serão corrigidos anualmente pelo IGPM da Fundação Getúlio Vargas. (...)

Art. $6^{0}$ - Os recursos obtidos através da cobrança da TAXA DE PRESERVAÇÃO AMBIENTAL - TPA serão destinados prioritariamente a projetos de educação ambiental, limpeza e conservação das áreas ambientalmente protegidas, e serão depositados na conta do Fundo Municipal do Meio Ambiente."

Percebe-se, portanto, que a lei tenta proteger o meio ambiente por meio da criação de uma taxa que financie os gastos públicos resultantes da degradação ambiental. Como muitas cidades litorâneas, Ilhabela recebe muitos turistas, e tal situação evidentemente causa grandes danos aos ecossistemas próximos ao mar.

Contra a referida lei, no entanto, foi proposta Ação Direta de Inconstitucionalidade. No caso, o Órgão Especial do Tribunal de Justiça de São Paulo, em 11 de setembro de 2013, decidiu, por maioria de votos, pela improcedência da ação, assegurando, assim, a manutenção da constitucionalidade da referida lei.

A Ementa do caso $^{153}$ dispõe:

“AÇÃO DIRETA DE INCONSTITUCIONALIDADE - LEI $\mathrm{N}^{\circ}$ 547/2007, DO MUNICÍPIO DE ILHABELA, QUE CRIOU A TAXA DE PRESERVAÇÃO AMBIENTAL - VULNERAÇÃO DOS ARTS. 160, II E 163, II, DA CONSTITUIÇÃO BANDEIRANTE DESCONFORMIDADE DO REGRAMENTO MUNICIPAL COM A DISCIPLINA TRIBUTÁRIA PÁTRIA, EM ESPECIAL NO QUE TANGE AO CONCEITO DE TAXA - INOCORRÊNCIA - LEI QUE

OBEDECEU A TODOS OS REQUISITOS DO PROCESSO LEGISLATIVO E SIMBOLIZA A CONCRETIZAÇÃO DA VONTADE POPULAR DEMOCRATICAMENTE

REPRESENTADA -"TAXA" QUE, À FALTA DE MELHOR DENOMINAÇÃO, SERVE COMO COMANDO COGENTE E

\footnotetext{
${ }^{153}$ Ação Direta de Inconstitucionalidade 0067959-37.2013 - São Paulo, Rel. Desembargador Renato Nalini. Órgão Especial do Tribunal de Justiça de São Paulo, julgado em 11/09/2013.
} 
ATENDE AO CAPUT DO ART. 225 DA CONSTITUIÇÃO FEDERAL DE 1988 E DÁ CONCRETUDE AO DIREITO AO MEIO AMBIENTE ECOLOGICAMENTE EQUILIBRADO, FUNDAMENTO INATO DA DIGNIDADE DA PESSOA HUMANA E DO DIREITO À VIDA - EVIDENTE INCOMPATIBILIDADE DO PEDIDO FRENTE À MISSÃO INSTITUCIONAL DO MINISTÉRIO PÚBLICO - AÇÃO IMPROCEDENTE”' (grifos nossos).

Os principais argumentos do Desembargador Relator Renato Nalini fundam-se na tutela do meio ambiente, cuja proteção claramente configura-se como legítimo interesse local. De acordo com o Desembargador:

"Evidente que a lei impugnada não fere o princípio da isonomia, na medida em que se destina a regular de maneira uniforme a situação dos veículos automotores, excetuados os automóveis oficiais e as ambulâncias (art. 5o, II), que não carregam placas do Município de Ilhabela. O motivo é de enorme singeleza: a Municipalidade, uma das únicas cidade-arquipélago do Brasil, em razão de seu caráter litorâneo, sofre os efeitos deletérios decorrentes do crescente fluxo de turistas. Estes ocupam a modesta infraestrutura com seus carros em feriados e finais de semana, além dos períodos de férias. Os efeitos deletérios ao equilíbrio ambiental são de conhecimento geral. Não há necessidade de erudição científica para constatá-los.

Não são os 28 mil habitantes - dados do censo de 2010 - os detratores ambientais. Mas a população flutuante, em número seguramente maior do que a população local, que usufrui do patrimônio natural que não foi criado por ação do homem. Mas que está sendo aceleradamente destruído pela insensatez humana.

A situação não é escoteira, mas análoga à do arquipélago de Fernando de Noronha. Ali, a taxa ambiental foi instituída com o fim de "garantir a utilização, efetiva ou potencial, por parte das pessoas visitantes, da infraestrutura física implantada no Distrito Estadual e o acesso e fruição ao seu patrimônio natural e histórico, fato gerador da Taxa de Preservação Ambiental- TPA".

Assim, como esclarece o magistrado, tal previsão não é exclusividade do Município de Ilhabela, presente de forma semelhante também no arquipélago de Fernando de Noronha, no qual também há previsão de uma Taxa de 
Preservação Ambiental - TPA. O Desembargador Relator Nalini ainda deixou claro que o "Município exerceu legítimo interesse e não poderia dispor sobre a matéria mediante instrumento diverso", ou seja, dever-se-ia realmente tratar-se da figura da taxa.

É ressaltado no voto, também, o caráter excepcional da declaração de inconstitucionalidade, conforme citação de trecho do Ministro Gilmar Mendes pelo referido Desembargador:

\footnotetext{
"Ressalta-se, por um lado, que a supremacia da Constituição impõe que todas as normas jurídicas ordinárias sejam interpretadas em consonância com seu texto. Em favor da admissibilidade da interpretação conforme a Constituição, milita também a presunção da constitucionalidade da lei, fundada na ideia de que o legislador não poderia ter pretendido votar lei inconstitucional (MENDES, Gilmar Ferreira. Jurisdição Constitucional. O controle abstrato de normas no Brasil e na Alemanha. São Paulo: Saraiva, 1996, p. 270.)".
}

Válido citar que a referida Ação Direta de Inconstitucionalidade não foi julgada improcedente por unanimidade, sendo interessante tratar brevemente dos argumentos colocados pelo Desembargador Luis Ganzerla, que proferiu o voto vencido. Para ele, “alcança-se, destarte, não se tratar de serviço público divisível, razão pela qual não se encaixa na descrição do fato gerador da taxa e, por conseguinte, inviável sua instituição e cobrança".

Além da questão de criticar a utilização da figura da taxa para a referida situação, o magistrado também afirma que:

"Acrescente-se o fato da lei ora guerreada instituir um tratamento desigual entre contribuintes em condição equivalente, na medida em que privilegia os veículos licenciados no Município, em nítida afronta ao princípio da isonomia, nos termos dos art. 150, II, da Constituição Federal e art. 163, II, da Constituição Bandeirante.”

Nota-se, portanto, que as questões que remetem à suposta inconstitucionalidade desta lei não tratam da competência do Município para legislar sobre questões ambientais. Tanto para os Desembargadores que votaram pela improcedência da ação, quanto para o Desembargador Luis Ganzerla, que foi voto vencido, a possibilidade de o Município editar lei que procura ampliar a tutela do meio ambiente nem foi trazida como possível matéria de inconstitucionalidade. 
Assim, sem adentrar no mérito da questão tributária - se poderia, ou não, o tributo ser instituído por meio de taxa -, percebe-se, uma vez mais, que não há óbice à edição de leis por parte de Municípios que visem proteger o meio ambiente equilibrado e sustentável.

\subsection{A proibição da extração de minérios}

Outro tema que coloca em pauta a questão da competência dos Municípios para legislar sobre matérias ambientais refere-se à extração e ao beneficiamento de minérios. Alguns Municípios, visando à proteção do meio ambiente, têm editado leis proibindo a extração de minérios - como o carvão - em seu território.

Será analisado especificamente o caso do carvão mineral, que se revela um grande perigo ao meio ambiente, devido ao alto grau de poluição que gera. Deve-se levar em conta, portanto, o fato dos enormes prejuízos que tal extração causa ao meio ambiente e à saúde da população, seja pela contaminação do ar (na utilização do carvão como fonte de energia), seja pela contaminação de mananciais e florestas na exploração do minério.

Analisando tais danos ao meio ambiente e o fato de que existem diversos outros recursos menos danosos ao meio ambiente que podem ser utilizados no lugar do carvão mineral, parece haver fundamentação para tal proibição realizada por alguns Municípios.

Como exemplo, a Lei $\mathrm{n}^{\circ} 2858$, de 17 de fevereiro de 2010, do Município de Araranguá, prevê que:

“Art. $1^{\circ}$ Fica proibida a extração de Carvão Mineral, bem como as atividades relacionadas ao beneficiamento e queima de carvão mineral em todo o território do Município de Araranguá.

Art. $2^{\mathbf{o}}$ A presente lei visa preservar os recursos naturais, em especial os recursos hídricos, tais como mananciais, nascentes e olhos d’água que abastecem a população do município, a fauna e a floresta nativa e transplantada, as regiões ribeirinhas, mangues e estuários, bem como possibilitar e melhorar o nível de vida da população, ao assegurar o bemestar da cidadã e do cidadão araranguaense.

Art. $3^{\circ}$ Não será concedida licença municipal para pesquisas a este referido fim, independente de autorização federal, estadual a pessoas 
físicas e jurídicas interessadas na extração e beneficiamento de carvão mineral, face a proibição constante no $\operatorname{art.} 1^{\circ}$ da presente lei.

Art. $4^{\mathbf{0}}$ Às infrações às disposições da presente lei acarretará a imposição de multa pecuniária no valor de 5.000 UFM (Unidade Fiscal do Município), e, no caso de reincidência, será aplicada multa em dobro.

Art. $5^{\circ}$ Contra o infrator será expedida autuação e notificação para fazer cessar o ato ou fato, no prazo máximo de cinco dias, a contar da data da ciência.

$\S 1^{\circ}$ Após o decurso do prazo de cinco dias, sem que cesse a infração, o Município de Araranguá, através do Departamento de Meio Ambiente, no exercício do Poder de Polícia, poderá embargar, desocupar a área, e/ou fazer cessar a infração.

$\S 2^{\circ}$ Após a notificação e autuação, o infrator terá o prazo de trinta dias para oferecer defesa ao Conselho Ambiental do Município de Araranguá (COAMA).

$\S 3^{\circ} \mathrm{A}$ multa prevista na presente lei deverá ser recolhida ao Município no prazo máximo de trinta dias, contados da notificação e autuação, sendo revertida a FAMA (Fundação Ambiental do Município de Araranguá) onde será revertida em projetos ambientais.

$\S 4^{\circ}$ Caso o infrator não recolha a multa no prazo previsto no $\S 3^{\circ}$, deste artigo, o seu valor será devidamente corrigido monetariamente e será inscrito em dívida ativa, para cobrança judicial."

Como se pode observar, o artigo $1^{\circ}$ da lei proíbe a extração de Carvão Mineral, bem como as atividades correlatas, em todo o território do Município da Araranguá. Interessante notar que o artigo $2^{\circ}$ traz uma justificativa para lei, elencando o que se pretende proteger por meio da norma. Cita-se a proteção aos mananciais, nascentes, florestas nativas etc.

Assim, visando a tutelar de modo mais amplo o meio ambiente e a também a saúde pública, o Município de Araranguá, prestigiando os interesses locais, editou a referida lei em consonância com sua competência constitucional de legislar suplementarmente à legislação federal.

No entanto, como se podia esperar, houve a propositura de Ação Direta de Inconstitucionalidade contra referida lei, proposta pelo Sindicato da Indústria da Extração do Carvão de Santa Catarina (Siecesc). A ADI n 2010.053600-1, julgada pelo órgão especial do Tribunal de Justiça de Santa Catarina, de relatoria do Desembargador José Volpato de Souza, declarou inconstitucional a referida lei.

O Ministério Público de Santa Catarina, por outro lado, manifestouse pela constitucionalidade da mencionada lei, por entender que se trata de matéria de 
interesse local, consubstanciada por medidas que visam à manutenção do meio ambiente ecologicamente equilibrado e que não haveria qualquer desrespeito à Constituição.

No mesmo sentido da manifestação ministerial, é sabido que a proteção do meio ambiente deve prevalecer sobre eventuais prejuízos econômicos de determinadas empresas. Sabe-se que há diversos recursos alternativos ao carvão mineral, não sendo, deste modo, a única fonte de energia disponível para a atividade industrial do País.

Assim, nada obsta que um Município, que sofra todos os malefícios da exploração desse minério, venha a produzir leis no sentido de tornar mais rígida ou impedir a exploração, beneficiamento e queima do carvão mineral. Conforme já foi mencionado em outros casos, o Município ostenta competência para legislar sobre matéria ambiental, desde que para ampliar sua proteção.

Mostra-se importante expor a ementa do caso:

"EMENTA: AÇÃO DIRETA DE INCONSTITUCIONALIDADE. DEMANDA PROPOSTA PELO SINDICATO DA INDÚSTRIA DA EXTRAÇÃO DE CARVÃO DO ESTADO DE SANTA CATARINA SIECESC. LEI N. 2.858/2010 QUE VEDA A EXTRAÇÃO DE CARVÃO MINERAL NO MUNICÍPIO DE ARARANGUÁ. ALEGAÇÃO DE OFENSA AOS INCISOS I E II DO ART. 112 DA CONSTITUIÇÃO ESTADUAL E A PRINCÍPIOS CONSTITUCIONAIS. NORMA LOCAL QUE EXTRAPOLOU SUA COMPETÊNCIA PARA LEGISLAR. PROIBIÇÃO QUE IMPOSSIBILITA QUALQUER FORMA DE EXPLORAÇÃO DE CARVÃO. MINÉRIO QUE POSSUI FONTE ESGOTÁVEL E EXISTENTE APENAS EM DETERMINADOS PONTOS DO TERRITÓRIO NACIONAL. NECESSIDADE DE SE EQUACIONAR A POSSIBILIDADE DE UTILIZAÇÃO DOS RECURSOS NATURAIS COM A PROTEÇÃO AMBIENTAL, PORÉM SEM PROIBIÇÃO INTEGRAL E IRRESTRITA. PROCEDÊNCIA DA AÇÃO. EMENTA: EMBARGOS DE DECLARAÇÃO. AÇÃO DIRETA DE INCONSTITUCIONALIDADE JULGADA PROCEDENTE."

Percebe-se, diante do teor da ementa, que o Tribunal de Justiça entendeu que o vício da lei estaria estritamente ligado ao fato de ela impedir "qualquer forma de exploração" sendo que, de acordo com os desembargadores, deve-se "equacionar 
a possibilidade de utilização dos recursos naturais com a proteção ambiental, porém sem a proibição integral e irrestrita".

Poder-se-ia concordar com as afirmações dos desembargadores caso não houvesse outros recursos que pudessem ser utilizados como alternativa ao carvão mineral. No entanto, tratando-se de tão somente mais uma fonte de energia, sendo inclusive uma das mais prejudiciais ao meio ambiente e à saúde da população, se mostra legítima a decisão do Município em buscar vedar referida atividade em seu território.

A norma, portanto, mostra-se efetiva na proteção do meio ambiente. No caso em análise, verifica-se que a atividade objeto da restrição total é extremamente danosa às florestas, águas, mananciais etc., de modo que a mera restrição parcial poderia não ser suficiente à proteção adequada do meio ambiente. Se não bastasse, a extração do carvão mineral traz inúmeros danos às pessoas que se encontram próximas das minas, de forma que referida lei se mostra efetiva para a prevenção de doenças, materializando o dever do Estado em garantir a saúde pública aos cidadãos.

No mais, tal proibição também não impede o desenvolvimento industrial, já que há diversas outras fontes muito menos poluentes que podem ser usadas em alternativa ao carvão mineral. Assim, considerando que o Município pode legislar sobre matéria ambiental para amplificar sua proteção, assim como para salvaguardar a saúde pública, entendemos não haver, data venia, qualquer inconstitucionalidade na referida lei. Em que pese o posicionamento do Tribunal de Justiça local, trata-se, a nosso ver, de norma constitucional, que busca efetivar interesse local, visando à proteção efetiva e ampla do meio ambiente e da saúde da população.

\subsection{Casos baseados no princípio da precaução:}

Além dos casos que já foram abordados, outros dois que se destacam estão estreitamente relacionados com o princípio da precaução: o caso da poluição eletromagnética e o dos organismos geneticamente modificados (OGM). Em ambos os casos, ainda há dúvida na comunidade científica quanto à extensão e potencialidade de eventuais danos ao meio ambiente e à saúde pública. Assim, importante tratar brevemente de tal princípio para que se possa passar à análise de cada um desses casos. 
Solange Teles da Silva, ao tratar do princípio da precaução, cita o breve e explicativo trecho de Philippe Kourilsky e Genevière Viney. Para eles, este princípio ambiental:

"define a atitude que devem tomar todos aqueles que adotam uma decisão relacionada à atividade, que se suponha possa comportar razoavelmente um perigo grave para a saúde ou para a segurança das gerações atuais ou futuras, ou para o meio ambiente. Impõe-se especialmente aos poderes públicos que devem fazer prevalecer os imperativos da saúde e da segurança sobre a liberdade comercial entre particulares e entre Estados. Conduz à adoção de todos os dispositivos que permitam, por um custo econômica e socialmente suportável, detectar e avaliar o risco e reduzi-lo a um nível aceitável e, se possível, eliminá-lo, informando as pessoas e recolhendo suas sugestões sobre as medidas a serem implementadas. Este dispositivo de precaução deve ser proporcional à amplitude do risco e pode ser revisado a qualquer momento ${ }^{154}$.

A partir desta citação, a mesma autora passa a analisar o princípio da precaução, que, segundo ela:

“envolve uma nova dimensão da gestão do meio ambiente na busca do desenvolvimento sustentável e da minimização dos riscos. Diante dos progressos tecnológicos das sociedades contemporâneas, o princípio da precaução busca implementar uma lógica de segurança suplementar que vai além da ótica e questiona a razão do desenvolvimento das atividades humanas, em função de uma melhora qualitativa de vida para o homem, no presente e no futuro. Ele constitui o fio condutor da lógica da proteção ambiental, da defesa e da preservação do meio ambiente para as gerações presentes e vindouras" ${ }^{, 155}$.

Já Marcelo Dias Varella ${ }^{156}$, de modo um pouco diverso, entende que referido princípio serve para conciliar o desenvolvimento econômico com a proteção do meio ambiente:

\footnotetext{
${ }^{154}$ SILVA, Solange Teles da. Princípio da precaução: uma nova postura em face dos riscos e incertezas científicas in VARELLA, Marcelo Dias e PLATIAU, Ana Flávia Barros (Orgs). Princípio da Precaução. p. $81 / 82$.

${ }^{155}$ SILVA, Solange Teles da. Op. cit. p. 84/85.

${ }^{156}$ VARELLA, Marcelo Dias. Variações sobre um mesmo tema: o exemplo da implementação do princípio da precaução pela CIJ, OMC, CJCE e EUA in VARELLA, Marcelo Dias e PLATIAU, Ana Flávia Barros (Orgs). Princípio da Precaução. Belo Horizonte: Del Rey, 2004, p. 275
} 
"O princípio da precaução não é uma norma dogmática, imposta diretamente, mas de um princípio, que guia formas de agir, tanto dos administradores públicos quando dos operadores jurídicos. Além de ser um princípio, é um princípio recente no direito ambiental que está em processo de expansão e consolidação rápida, já tendo sido inclusive positivado em diversas normas nacionais e internacionais, mas que ainda luta por sua aceitação nas mais diversas esferas de ação jurídica e política. Certos tratados o consideram apenas uma "abordagem". Ainda que não exista uma definição de abordagem ou enfoque, estes seriam conceitos mais amenos em relação aos princípios".

Assim, diante dos diferentes aspectos apresentados, pode-se vislumbrar que a aplicação do princípio da precaução poderá ser materializada em leis municipais que promovam uma ampliação na proteção das pessoas e do meio ambiente diante da possibilidade de risco de danos. Assim, embora ainda haja dúvida quanto aos reais efeitos maléficos à saúde em tais casos, seria salutar que o legislador local protegesse os direitos individuais e coletivos que eventualmente estiverem ameaçados.

O direito ao meio ambiente sustentável e o direito à saúde devem, portanto, ser tutelados de modo amplo, de modo que, caso haja dúvida na comunidade científica a respeito da existência de danos à saúde e ao meio ambiente, o Poder Público estará legitimado a agir de forma cautelosa, protegendo os seres humanos e o ambiente em que vivem.

Somente poderá ser recusada a edição de uma norma se houvesse conclusão efetiva sobre a inexistência de danos às pessoas e ao meio ambiente. Enquanto existir dúvida a respeito de tais danos, não há como não se aceitar ações governamentais no sentido de proteção efetiva de todos.

\subsection{1 - Restrição aos organismos geneticamente modificados}

Um dos temas mais discutidos, em âmbito nacional e internacional, diz respeito aos alimentos transgênicos (ou organismos geneticamente modificados), que são fruto do avanço do processo biotecnológico na agricultura. Para diversas entidades nacionais e internacionais, os organismos geneticamente modificados (OGMs) são 
prejudiciais à saúde e ao meio ambiente, sendo por vezes restritos em alguns países, notadamente na Europa.

Em defesa destes alimentos, por outro lado, estão aqueles que apontam sua existência como essencial para a solução do problema da fome mundial. Em razão da crescente demanda por alimentos, é afirmado que não haverá alimentos para todos no planeta em alguns anos, sendo os alimentos transgênicos indispensáveis para suprir tal necessidade.

Neste sentido, Tereza Ancona Lopez ${ }^{157}$ apresenta tal dualidade referente ao tema, inclinando-se favoravelmente à utilização dos OGMs:

"os defensores da comercialização dos OGMs afirmam que essa é a única saída para a "fome" que poderá existir nos quatro cantos do planeta em futuro não tão longínquo (cumprindo a profecia de Malthus, conhecida como "catástrofe malthusiana"). Além disso, esses alimentos não necessitam de agrotóxicos que comprovadamente fazem mal à saúde. Seus opositores, que trabalham com hipóteses, afirmam que esses produtos prejudicam a saúde (no que?) e acabam com o meio ambiente".

A professa da Universidade de São Paulo critica, ainda, o sinal indicativo que deve ser utilizado no caso de transgenia dos produtos, afirmando que ao leigo pode parecer que o produto é "venenoso ou extremamente prejudicial à saúde" No entanto, a sinalização trazida pela lei procura contemplar o dever de informação presente no Código de Defesa do Consumidor. Seu artigo $6^{\circ}$, inciso III, estabelece que é direito básico do consumidor "a informação adequada e clara sobre os diferentes produtos e serviços, com especificação correta de quantidade, características, composição, qualidade, tributos incidentes e preço, bem como sobre os riscos que apresentem".

Justamente quanto a esta polêmica questão, houve propositura de uma Ação Direta de Inconstitucionalidade, por parte da Confederação Nacional de Indústria (CNI), contra a Lei $\mathrm{n}^{\circ}$ 14.274, do Estado de São Paulo, de 16 de dezembro de 2010, que trata da rotulagem dos produtos transgênicos no Estado, dentre outras providências.

${ }^{157}$ LOPEZ, Teresa Ancona. Princípio da Precaução e evolução da responsabilidade civil. São Paulo: Quartier Latin, 2010 p. 212.

${ }^{158}$ LOPEZ, Teresa Ancona. Op. cit. p. 221. 
Para referida Confederação Nacional de Indústria a mencionada lei é inconstitucional, dentre outras alegações, pelo fato de seu conteúdo não se enquadrar na competência residual e suplementar, que não se trataria de mero preenchimento de lacunas ou detalhamento de condutas. Assim, tal competência seria reservada à esfera federal, sendo que o ente estadual teria extrapolado os limites da competência concorrente.

A Confederação reitera, ainda, que somente compete aos Estados, Distrito Federal e Municípios editarem normas que sejam suplementares à legislação federal, de modo que a competência das normas gerais é privativa da União. Segundo a CNI, portanto, o fato de já existirem leis regulando o direito de informação do consumidor (Código de Defesa do Consumidor -lei 8.078/90- e Lei de Biossegurança -lei 11.105/2005) impediria que lei estadual ou municipal trata-se do tema.

Manifestaram-se pela inconstitucionalidade da referida lei, também, o Governo do Estado de São Paulo (a lei foi objeto de veto total, posteriormente derrubado pelo Poder Legislativo) e a Advocacia-Geral da União, ambos fundamentando tal posicionamento na suposta invasão de competência privativa do Poder Executivo.

O Ministério Público Federal, entretanto, manifestou-se em seu parecer $^{159}$ pela constitucionalidade da lei. Constatou-se na referida manifestação que os temas em pauta nesta Ação Direta de Inconstitucionalidade estão "sob o domínio de competência legislativa concorrente", ressaltando que caberia à União "apenas estabelecer as normas gerais, e aos Estados, as normas suplementares”.

Assim, o parecer ainda ressalta que, em que pese não haver consenso na doutrina e jurisprudência quanto à definição exata do termo "normas gerais", seria possível afirmar que a União deveria traçar somente normas principiológicas, as linhas gerais de cada tema, sem, todavia, estabelecer os pormenores.

Percebe-se, portanto, que a análise do que são "normas gerais" tornase muito importante para que se possa auferir aquilo que é matéria reservada à União e aquilo que pode ser previsto pelos Estados e Municípios. Questões pontuais e específicas, deste modo, desde que respeitados os princípios e as generalidades prescritas na lei federal, poderão ser objeto de lei estadual e municipal.

Evidente que, dependendo da amplitude que se dá ao termo "normas gerais", poder-se-á aumentar ou diminuir a margem de possibilidades dos outros entes

${ }^{159}$ Disponível em: http://noticias.pgr.mpf.mp.br/noticias/noticias-do-site/copy_of_pdfs/ADI\%204619.pdf 
federativos legislarem quanto aos temas em que há a competência concorrente. No caso em questão, da regra quanto à rotulação dos produtos transgênicos, parece evidente que não se trata de regramento geral ou de princípios, mas exatamente de disposição específica suplementar às regras já estabelecidas em lei federal, estando, deste modo, de acordo com a Constituição Federal, não invadindo competência da União.

Neste sentido, o Parquet cita Diogo de Figueiredo Moreira Neto ${ }^{160}$, que traz ensinamentos de outros doutrinadores, afirmando que: "as normas gerais (...) não podem descer a pormenores (Einzelheiten), porque elas conformam uma moldura (Rahmen) dentro da qual legislam as entidades locais." E, ainda, que há "limitação constitucional à União para dispor apenas sobre o genérico, vedando-lhe a normatividade particularizante". Outro autor citado, que traz entendimento semelhante, é Cláudio Pacheco $^{161}$ :

\begin{abstract}
“[...] as normas gerais serão os lineamentos fundamentais da matéria, serão as estipulações que apenas dão estrutura, plano e orientação. Podese conceituar ainda, pelo efeito indireto e fracionário de negativas, que serão aquelas que não especificarão, que não aplicarão soluções optativas, que não concretizarão procedimentos, que não criarão direções e serviços, que não selecionarão e discriminarão atividades, que não preceituarão para a emergência, para a oportunidade, a modalidade especial e para o caso ocorrente, que não condicionarão a adaptabilidade, que não descerão a minúcias e requisitos."
\end{abstract}

Com relação especificamente à questão dos organismos geneticamente modificados, restou afirmado que "especificamente quanto à sua rotulagem, parece razoável sustentar que o regramento mais geral compete à União. Já os detalhamentos, e assim se considera o percentual de presença desses organismos no produto, possa ser definido por cada Estado."

O Parquet faz menção, ainda, ao voto do Ministro Lewandowski quanto à questão dos produtos que contém amianto ${ }^{162}$, que em muito se assemelha ao presente caso. O referido Ministro do Supremo Tribunal Federal afirmou que:

\footnotetext{
${ }^{160}$ MOREIRA NETO, Diogo de Figueiredo. Competência concorrente limitada. In: Revista de Informação Legislativa, a. 25, n. 100, out/dez 1988, p 141.

${ }^{161}$ PACHECO, Cláudio, Tratado das Constituições Brasileiras, vol. II, Rio-São Paulo: Ed. Livraria Freitas Barros, 1958, p.255.

${ }^{162}$ ADI 3927, Re. Min. Marco Aurélio (vencido na deliberação do pedido cautelar), DJe 192, de 10.10.2008.
} 
"Como argumento final, tenho defendido não apenas em sede acadêmica, mas também em algumas decisões que já proferi já na corte estadual a que pertenci, como também tive oportunidade de manifestar esse entendimento nesta Suprema corte, no sentido de que, em matéria de proteção ao meio ambiente e em matéria de defesa da saúde pública, nada impede que a legislação estadual e a legislação municipal sejam mais restritivas do que a legislação da União e a legislação do próprio Estado, em se tratando dos municípios." (grifos nossos)

O Supremo Tribunal Federal ainda não decidiu o mérito da Ação Direta de Inconstitucionalidade n. 4.619, de relatoria da Ministra Rosa Weber, que irá analisar o parecer do Ministério Público Federal. Entretanto, como pôde ser visto, alguns Ministros e muitos doutrinadores entendem pela possibilidade de legislação mais restritiva dos Estados, Distrito Federal e Municípios em matérias de competência concorrentes.

Importante frisar, também, o escopo da lei ora em análise, qual seja, o de ampliar a proteção em relação à tutela do consumidor. Ou seja, além de se tratar de uma lei que regula questão específica e supletiva aos regramentos federais, a Lei 14.274 do Estado de São Paulo prevê uma tutela mais completa e ostensiva ao consumidor, por meio da imposição de sinal informativo da presença de produtos transgênicos.

Sendo assim, tal lei não só respeita os preceitos constitucionais quanto à matéria de competência - pois suplementa o dever de informação já previsto no Código de Consumidor - como também prestigia este direito fundamental do cidadão. Referido regramento ainda fortalece o direito à saúde e à higidez do meio ambiente, pois as pessoas que forem contrárias ao uso de transgênicos poderão deixar de comprar os produtos das empresas que se utilizam desta técnica.

Percebe-se, assim, que esta lei está em consonância com o princípio da precaução, haja vista que o devido e completo fornecimento de informação para o consumidor é essencial para que este possa saber, e assim decidir, se deseja consumir um produto com organismo geneticamente modificado, cuja segurança alimentar é contestada por diversas fontes (assim, na dúvida quanto aos malefícios de tal alimento, o atendimento mínimo do princípio da precaução se dá com o acesso à informação).

Não se sustenta, por fim, o argumento da CNI, de que as disposições da mencionada lei "a toda evidência, promovem a substituição, e não a simples suplementação das regras federais que cuidam de disciplinar a produção, informação e 
comercialização de produtos transgênicos, em todo o Brasil", haja vista que a previsão de rotulação dos alimentos transgênicos não suprime ou substitui os regramentos da legislação federal, mas apenas adiciona uma disposição que amplia a tutela do consumidor, por meio de um acesso à informação mais completo.

Portanto, referida lei se mostra compatível com o sistema de proteção especial que os entes federativos podem fazer para melhorar os assuntos nos quais entender que a legislação federal é deficiente para tratar do tema.

\subsection{2 - Poluição Eletromagnética}

Outro exemplo polêmico quanto a questões ambientais que podem ser objeto de legislação estadual ou municipal está nas restrições quanto à instalação de antenas de celulares e redes de transmissão de energia (sobretudo em áreas muito povoadas), haja vista os riscos da denominada poluição eletromagnética.

\section{Elza Boiteux ${ }^{163}$ explica que:}

"Todo e qualquer uso de energia elétrica gera campos eletromagnéticos, inclusive a iluminação de nossas casas e a utilização de aparelhos eletrodomésticos. Em sentido amplo, pode-se afirmar que a exposição à radiação eletromagnética é parte integrante do uso disseminado de energia elétrica. Dependendo da quantidade de radiação que a pessoa receba, a energia elétrica pode deixar de representar apenas uma comodidade para a sua vida e passar a representar um risco para a saúde".

Ademais, a mesma autora ${ }^{164}$ também aponta diversas doenças que têm sido relacionadas à exposição da poluição eletromagnética (embasada em pesquisas feitas na última década):
"1 - leucemia em adultos e crianças;
2 - câncer no cérebro de adultos e crianças;
3- câncer de mama em homens e mulheres;
4- campos eletromagnéticos como agente carcinogênico de "amplo espectro" para todas as espécies de câncer;

\footnotetext{
163 BOITEUX, Elza Antonia P. C. e BOITEUX, Fernando Netto: Poluição Eletromagnética e Meio Ambiente. O princípio da precaução. Porto Alegre: Sergio Antonio Fabris Ed., 2008, p. 31.

${ }^{164}$ BOITEUX, Elza Antonia P. C. Op. cit. p. 42/43.
} 
5- aborto espontâneo;

6- outras disfunções da reprodução ou do desenvolvimento.

7- esclerose lateral amiotrófica (doença de Lou Gehrig);

8- mal de Alzheimer;

9- infarto agudo do miocárdio;

10- suicídio;

11- outras conseqüências nocivas à saúde, diversas do câncer (depressão, sensibilidade à eletricidade)"

Assim, mais uma vez torna-se importante relacionar tal questão ao princípio da precaução, haja vista que o risco relacionado à poluição eletromagnética não é aceito por todos. Assim como a questão dos organismos geneticamente modificados, há divergência entre os cientistas quanto à existência e relevância dos danos que podem ser causados às pessoas.

Deste modo, assumindo que existe dúvida quanto ao risco, que ainda não há posição consolidada pela comunidade científica, deve ser cabível a atitude mais protetiva, objetivando tutelar a saúde e a vida das pessoas diante de um risco. Tal posicionamento se reforça, sobretudo, pelo fato das doenças relacionadas a tal exposição serem muito graves.

É provável que, em alguns anos, diante da grande quantidade de pesquisas feitas na atualidade relativamente à questão dos perigos da exposição à poluição magnética, serão descobertas respostas mais concretas quanto à extensão dos riscos, de modo que será possível saber quais medidas efetivamente devem ser tomadas para a proteção das pessoas.

Assim, enquanto perdurar a dúvida quanto à dimensão do problema, deve ser válida a edição de leis, por parte dos Estados e Municípios, quanto às áreas que podem, ou não, receber antenas de celulares e redes de transmissão de energia, assim como quanto ao controle da radiação emitida (estabelecendo, por exemplo, uma redução nas áreas mais povoadas).

É plenamente plausível que se estabeleça, também, uma distância mínima da instalação destas em relação a áreas povoadas ou se estabeleça uma limitação no índice de radiação, a partir de estudos técnicos. 
Teresa Ancona Lopez ${ }^{165}$ afirma que, para proteger as pessoas da radiação eletromagnética, deve-se "ou abaixar a potência das antenas ou recuar as pessoas". Neste mesmo sentido, Elza Boiteux ${ }^{166}$ afirma que poderiam ser editadas normas que:

“(i) imponham a redução da radiação emitida pelas diversas fontes, de forma que a exposição a elas fique limitada a índices considerados seguros, segundo a melhor avaliação técnica disponível; (ii) estabeleçam a necessidade de informação dos usuários, de forma que eles possam formar a sua própria convicção sobre a existência de riscos e sobre as eventuais medidas de proteção que entendam necessárias."

A ressalva que deve ser feita, entretanto, relaciona-se ao fato de que as antenas e redes de transmissão são de extrema importância para a vida das pessoas na sociedade atual. Por óbvio, as legislações sobre o tema devem atender ao princípio da razoabilidade, uma vez que a proibição total e irrestrita da instalação de tais antenas não se justificaria.

Afinal, ainda não se sabe a extensão nem a potencialidade danosa desta poluição eletromagnética, sendo que, em regra, as pesquisas mencionadas restringem-se às áreas muito próximas às antenas e redes de transmissão, de modo que existe certo consenso de que a elevada proximidade com as antenas é que causariam riscos à saúde das pessoas.

Diante desse quadro, há diversas cidades que estão editando leis restringindo a instalação de antenas de celular e redes de transmissão de energia. A cidade de Porto Alegre, por exemplo, tem uma das legislações mais restritas neste campo. A lei municipal no 8.896/02, conhecida como "Lei das antenas", regulamenta a instalação e o licenciamento de antenas para emissão de sinais das Estações de Rádio Base (ERBs). A referida lei estabelece limites de 500 metros entre as torres, distância de 50 metros de hospitais e clínicas e de pelo menos 5 metros do terreno vizinho.

Há grande pressão por parte das empresas de telefonia, sobretudo devido a necessidade de instalação das antenas para a internet. Argumentam que a tecnologia $4 \mathrm{G}$ e o sinal de telefonia e internet devem estar em padrões aceitáveis para a

165 LOPEZ, Teresa Ancona. Princípio da Precaução e evolução da responsabilidade civil. São Paulo: Quartier Latin, 2010 p. 225.

${ }^{166}$ BOITEUX, Elza Antonia P. C. Op. cit. p. 31. 
Copa do Mundo de Futebol em 2014, sendo que as regras demasiadamente protetivas impedem que o serviço seja prestado adequadamente.

No caso, foi instaurada uma Comissão Parlamentar de Inquérito em relação ao tema na Câmara Municipal, denominada "CPI da telefonia”, para avaliar as regras estabelecidas para a lei municipal mencionada. Além da CPI (que ainda não obteve conclusões), há alguns projetos de lei em tramitação para revogar a lei n⿳0 8.896/02, prevendo regulação menos restrita quanto à instalação das ERBs.

O Ministério Público, que tem promotoria especializada em Direito Ambiental na cidade, mostra-se veemente contra tais alterações, que visam amenizar o rigor das regras já estabelecidas. Afirma que é plenamente possível haver o respeito a tais parâmetros juntamente com a prestação de um bom serviço, afinal as regras nem seriam tão rígidas.

Eduardo Levy ${ }^{167}$, diretor executivo do sindicato que representa operadoras de telefonia celular (SinditeleBrasil), é um dos favoráveis a nova legislação que revogue a polêmica "Lei das Antenas". Afirma que $88 \%$ da área urbana é atingida pela restrição legal, dificultando a prestação do serviço de telefonia. Ressalta, também, a necessidade de instalação de muitas antenas para implantar a rede 4G.

A suposta inconstitucionalidade da lei municipal $n^{0} 8.896 / 02$ já foi suscitada incidentalmente em algumas ações, por parte de empresas de telefonia. No Recurso Extraordinário $587814^{168}$ do Rio Grande do Sul, de relatoria do Ministro Joaquim Barbosa, a empresa VIVO S/A alegou a incompetência do Município para legislar sobre telecomunicações, por se tratar, supostamente, de matéria de competência privativa da União.

Por questões processuais (falta de prequestionamento) a decisão não adentrou no mérito da constitucionalidade da lei:

"DECISÃO: Trata-se de recurso extraordinário (art. 102, III, $\underline{\text { a }}$, da Constituição Federal) que tem como violado o art. $\underline{5^{\circ}}, \underline{\mathrm{LIV}}$ e LV da Carta Magna, além de alegar a inconstitucionalidade

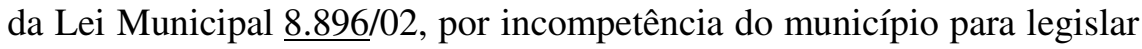
sobre telecomunicações, matéria de competência privativa da União. O

167 Disponível em: http://gaucha.clicrbs.com.br/rs/noticia-aberta/sindicato-cobra-agilidade-em-lei-sobreinstalacao-de-antenas-de-celular-5097.html

${ }^{168}$ Recurso Extraordinário 587814, Rel. Min. Joaquim Barbosa, julgado em 15 de maio de 2009. 
recurso extraordinário, ao alegar a inconstitucionalidade da Lei Municipal 8.896/02, por incompetência do município para legislar sobre telecomunicações, versa questão constitucional não ventilada na decisão recorrida e que não foi objeto de embargos de declaração, faltando-lhe, pois, o indispensável prequestionamento (Súmulas 282 e 356). As demais questões constitucionais invocadas no recurso extraordinário constituem alegações de ofensa indireta ou reflexa à Constituição, o que dá margem ao descabimento do recurso extraordinário. Ademais, inexiste a alegada violação do art. $\underline{5^{\circ}} \underline{\text { LIV e }} \underline{\mathrm{LV}}$, da $\underline{\text { Constituição, }}$, pois o acórdão recorrido, ao julgar o recurso interposto, inequivocamente prestou jurisdição, em observância aos princípios do devido processo legal, do contraditório e da ampla defesa. Do exposto, nego seguimento ao recurso extraordinário. Publique-se. Brasília, 15 de maio de 2009 Ministro JOAQUIM BARBOSA Relator.”

Em caso semelhante, no Agravo de Instrumento $\mathrm{n}^{\mathrm{o}} 765586^{169}$ do Rio Grande do Sul, a empresa TELECOM S/A também alegou a inconstitucionalidade da lei municipal, em que a Ministra Relatora Ellen Gracie entendeu pela impossibilidade de examinar a legislação local em fase recursal, devido à Súmula 280 do STF. Assim restou decidido:

"Trata-se de agravo de instrumento de decisão que inadmitiu recurso extraordinário interposto de acórdão assim do:“TELEFONIA MÓVEL. LICENÇA PARA FUNCIONAMENTO DE ESTAÇÃO DE RÁDIO BASE. DEMORA NA APRECIAÇÃO. INOCORRÊNCIA. HONORÁRIOS ADVOCATÍCIOS." (fl. 57).No RE, alega-se ofensa aos arts. 5', XXXIII; XXXIV; LIV; LV e LXXVIII; e 37, caput, da Constituição Federal (fls. 108-121).2. O recurso não merece prosperar. Para divergir da conclusão a que chegou o Tribunal a quo, cumpriria

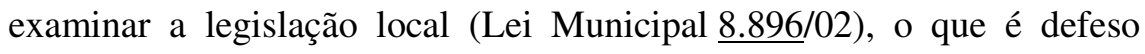
nesta fase recursal, nos termos da Súmula/STF 280. Quanto à alegação de ofensa ao art. $\underline{5^{\circ}}$ e seus incisos, da Constituição Federal, a jurisprudência desta Corte está sedimentada no sentido de que as alegações de desrespeito aos postulados da legalidade, do devido processo legal, do direito adquirido, do ato jurídico perfeito, da motivação dos atos decisórios, do contraditório, dos limites da coisa julgada e da prestação

${ }^{169}$ Agravo de Instrumento n ${ }^{\text {o } 765586, ~ R e l . ~ M i n . ~ E l l e n ~ G r a c i e ~ R e l a t o r a, ~ j u l g a d o ~ e m ~} 22$ de dezembro de 2009 
jurisdicional podem configurar, quando muito, situações de ofensa meramente reflexa ao texto da Constituição,circunstância essa que impede a utilização do recurso extraordinário. Nesse sentido: AI 372.358AgR/SP, Rel. Min. Celso de Mello, $2^{a}$ Turma, unânime, DJ 26.06.2002; RE 461.286-AgR/MS, rel. Min. Ricardo Lewandowski, $1^{\text {a }}$ Turma, unânime, DJ 15.9.2006; AI 682.065-AgR/RS, rel. Min. Eros Grau, $2^{\mathrm{a}}$ Turma, unânime, DJe 04.04.2008 e AI 662.319-AgR/RR, rel. Min. Ricardo Lewandowski, $1^{\text {a }}$ Turma, unânime, DJe 06.03.2009.4. Ante o exposto, nego seguimento ao agravo. Publique-se.Brasília, 22 de dezembro de 2009.Ministra Ellen Gracie Relatora ( $\underline{\mathrm{CPC}}$, art. $\underline{557}$, caput)."

Está em tramitação, no Tribunal de Justiça do Estado do Rio Grande do Sul, a arguição de inconstitucionalidade da lei n. ${ }^{\circ}$ 8.896/02, do Município de Porto Alegre. Ainda não há decisão quanto a este processo (n. ${ }^{\circ}$ 70055909964), o qual foi suscitado pelo Primeiro Grupo Cível do Tribunal de Justiça do Estado do Rio Grande do Sul em caso da BRASIL TELECOM CELULAR S.A.

A alegação de inconstitucionalidade é fundada na suposta incompetência do Município para legislar sobre a instalação e localização de estações rádio-base, haja vista os artigos 21, inciso XI, e 22, inciso IV, da Constituição Federal. Embora não haja decisão, já há parecer do Ministério Público.

O Parquet se manifestou pela constitucionalidade da referida lei em seu parecer (citando inclusive parecer próprio dado em outro expediente quanto à constitucionalidade da lei municipal n. ${ }^{\circ}$ 8.896/02). Mostra-se extremamente válido, assim, expor alguns dos ensinamentos apresentados, que incluem citações a vasta jurisprudência e posicionamentos doutrinários:

“Data venia, não se vislumbra vício algum na Lei atacada. (...)

Pode-se concluir, assim, que a Lei Municipal n. ${ }^{\circ}$ 8.896/02, do Município de Porto Alegre, ora impugnada, não desbordou da esfera de competência local, já que, por constituir emanação do poder de polícia do Município, tratou de interesse eminentemente local, sem interferir no âmbito de atuação dos demais entes federativos. Nada impede que o Município fixe regras urbanísticas para instalação de estações rádio bases "ERBs" - ou mesmo disponha sobre medidas sanitárias ou ambientais (proibição de instalação de torres próximo a hospitais, 
escolas etc.). Tudo isso constitui emanação do interesse local da Comuna.

Não se vislumbra qualquer desrespeito a regras federais e estaduais pela legislação municipal impugnada. Com efeito, mesmo que houvesse dispositivo sobre a matéria, é competência exclusiva das Comunas estabelecer normas urbanísticas e ambientais/sanitárias com base no interesse local, o qual é prevalente.

No que toca à questão urbanística, o objetivo principal da exigência da distância de 500 (quinhentos) metros entre as torres é evitar o chamado "efeito paliteiro", com a proliferação de estações rádio bases ("ERBs") sem qualquer preocupação estética. Evidentemente, compete aos Municípios definir a localização de tais torres, não havendo qualquer possibilidade de regramento imposto pela União ou pelo Estado, já que diz, exclusivamente, com o interesse local.

Relativamente à questão ambiental/sanitária, a assertiva da representante, no sentido de que "as telecomunicações não afetam de modo algum o meio-ambiente, o sossego, a higiene, muito menos colocam em risco a função ecológica da fauna e da flora", carece de qualquer atestação científica.

Ao contrário, os riscos a longo prazo da exposição a radiações eletromagnéticas não-ionizantes ainda são ignorados. Inúmeros distúrbios e enfermidades têm sido detectados e creditados a tal exposição, como informa Ana Maria Moreira Marchezan (em "As Estações de Rádio-base de Telefonia Celular no Contexto de uma Sociedade de Riscos", publicado em Caderno Jurídico, v. 6, n 2, São Paulo, ESMP, junho de 2004, p. 141-155).

Por isso, a precaução é medida que se impõe.” (grifos nossos)

O Procurador, então, cita algumas decisões que corroboram seu entendimento quanto ao tema:

“AÇÃO CIVIL PÚBLICA, MINISTÉRIO PÚBLICO. TELEFONIA CELULAR. INSTALAÇÃO DE ANTENA OU ESTAÇÃO RÁDIO BASE (ERB). PARALISAÇÃO DA OBRA. CONCESSÃO PARCIAL DE TUTELA ANTECIPADA. INCONFORMISMO. PRELIMINARES DE (1) FALTA DE INTERESSE DE AGIR DO FISCAL DA LEI, (2) 
TAMBÉM EM RELAÇÃO ÁS DEMAIS ESTAÇÕES RÁDIO BASE DE TELEFONIA CELULAR INSTALADAS NO MUNICÍPIO DE ANGRA DOS REIS, (3) DE ILEGITIMIDADE PASSIVA DA ATL, (4) DE LITISPENDÊNCIA EM RELAÇÃO A AÇÃO CIVIL PÚBLICA EM TRAMITAÇÃO PERANTE A $3^{\text {a }}$ VARA DA FAZENDA PÚBLICA DA COMARCA DA CAPITAL E (5) DE EXTINÇÃO DE FEITO, SEM APRECIAÇÃO DO MÉRITO, POR LITISPENDÊNCIA E AUSÊNCIA DAS CONDIÇÕES DA AÇÃO. NÃO CONHECIMENTO. A UMA, PORQUE A DECISÃO ATACADA, EM MOMENTO ALGUM, TRATA DAS REFERIDAS PRELIMINARES, A DUAS, PORQUE ESTARIA SENDO SUPRIMIDA A INSTÂNCIA RECURSAL. NO MÉRITO, AINDA NÃO HÁ CERTEZA SOBRE OS ALEGADOS EFEITOS NOCIVOS DAS ESTAÇÕES DE RÁDIO BASE DE TELEFONIA CELULAR. BEM AGIU A PROMOTORIA PÚBLICA EM BUSCAR A PARALISAÇÃO DA OBRA, CUJO ANDAMENTO APRESENTA CONTRADIÇÃO A SER DIRIMIDA NO JUÍzo SINGULAR, ANTE À IMPOSSIBILIDADE DA VIA ELEITA. INADMISSÍVEL PERMITIR SEU PROSSEGUIMENTO, SEM ANTES TER O CONHECIMENTO DOS SEUS EFEITOS AO MEIO AMBIENTE E À POPULAÇÃO DO LUGAREJO. AUSENTE QUALQUER ILEGALIDADE E ARBITRARIEDADE NA DECISÃO ATACADA. DESCABIDA A IRRESIGNAÇÃO, NO MEU SENTIR, DESPIDA DE FUNDAMENTO LEGAL. MANUTENÇÃO DA DECISÃO RECORRIDA. CONHECIMENTO E IMPROVIMENTO DO AGRAVO. (Agravo de Instrumento $\mathrm{n}^{\mathrm{o}} 23.136 / 2004,17^{\mathrm{a}}$ Câmara Cível/RJ)

AGRAVO DE INSTRUMENTO - TELEFONIA MÓVEL - LICENÇA PARA INSTALAÇÃO NO MUNICÍPIO DE ESTAÇÃO DE RÁDIO BASE - INSUFICIÊNCIA DO LICENCIAMENTO FORNECIDO PELA ANATEL PARA O FIM PRETENDIDO - NECESSIDADE DE A AGRAVADA SE SUBMETER ÀS EXIGÊNCIAS MUNICIPAIS PROVIDENCIANDO NO LICENCIAMENTO AMBIENTAL ANTECIPAÇÃO DE TUTELA QUE SE DESCONSTITUI. AGRAVO PROVIDO. (Agravo de Instrumento n ${ }^{\circ} 700010262939,4^{a}$ Câmara Cível, Comarca de Porto Alegre)". (grifos nossos) 
Mais especificamente quanto à questão da instalação de equipamentos transmissores de radiação eletromagnética, o eminente representante do Ministério Público ainda cita decisão do Órgão Especial do Tribunal de Justiça do Paraná, que considerou o Município competente para regulamentar tal matéria:

"DECISÃO: ACORDAM OS DESEMBARGADORES INTEGRANTES DO ÓRGÃO ESPECIAL, DO TRIBUNAL DE JUSTIÇA DO ESTADO DO PARANÁ, POR UNANIMIDADE DE VOTOS, EM DECLARAR A CONSTITUCIONALIDADE DA LEI ACIMA ENUNCIADA E REJEITAR ESTE INCIDENTE, COM A REMESSA DOS AUTOS, OPORTUNAMENTE, A CÂMARA DE ORIGEM PARA OS FINS E EFEITOS DE DIREITO, FAZENDO-SE AS NECESSÁRIAS COMUNICAÇÕES (ARTIGO 113, DA CONSTITUIÇÃO DO ESTADO DO PARANÁ). EMENTA: INCIDENTE DE DECLARAÇÃO DE INCONSTITUCIONALIDADE LEI N. 8.462/2001 DO MUNICÍPIO DE LONDRINA NORMAS QUE REGULAMENTAM A INSTALAÇÃO DE EQUIPAMENTOS TRANSMISSORES DE RADIAÇÃO ELETROMAGNÉTICA ATRIBUIÇÃO DE COMPETÊNCIA LEGISLATIVA E MATERIAL - DEVER CONSTITUCIONAL, IMPOSTO AO MUNICÍPIO, DE LEGISLAR E ZELAR PELO MEIO AMbIENTE, SAÚde PÚbliCA E PARCELAMENTO E USO DO SOLO URBANO ASSUNTOS DE INTERESSE LOCAL INEXISTÊNCIA DE AFRONTA A CONSTITUIÇÃO FEDERAL DECLARAÇÃO DE CONSTITUCIONALIDADE DA LEI 8.462/2001. INCIDENTE REJEITADO. AS NORMAS ATACADAS DE INCONSTITUCIONAIS, ESTATUÍDAS ATRAVÉS DOS ARTIGOS 3. E SEUS INCISOS; 7. E SEUS INCISOS II E VIII; 10; 11 E PARÁGRAFOS; $12 ; 13 ; 14 ; 15, \S 1 . ; 16$, I; 19; E, 21, TODOS DA LEI N. 8.462/2001, DO MUNICÍPIO DE LONDRINA, QUE REGULAMENTAM A INSTALAÇÃO DE EQUIPAMENTOS TRANSMISSORES DE RADIAÇÃO ELETROMAGNÉTICA, NÃO TRADUZEM AFRONTA A COMPETÊNCIA PRIVATIVA DA UNIÃO PARA LEGISLAR SOBRE TELECOMUNICAÇÕES. EM VEZ DISSO, COM A EDIÇÃO DE TAIS NORMAS, A MUNICIPALIDADE CUMPRE OS MANDAMENTOS CONTIDOS NA CARTA MAIOR, LEGISLANDO E ZELANDO POR BENS JURÍDICOS CUJA PROTEÇÃO TAMBÉM E DE SUA ALÇADA, 
COMO O MEIO AMBIENTE, A SAÚdE DA POPULAÇÃo E O PARCELAMENTO E USO DO SOLO URBANO. POR TAIS MOTIVOS, NÃO SE VISLUMBRA QUALQUER INCONSTITUCIONALIDADE NAS NORMAS REFERIDAS, SENDO DE RIGOR SUA MANUTENÇÃO NO ORDENAMENTO JURÍDICO. P.Z. (Processo: 13807120, Origem: LONDRINA - 5a. VARA CÍVEL Número do Acórdão: 6654 Decisão: Unânime Órgão Julgador: ÓRGÃO ESPECIAL Relator: ANTONIO GOMES DA SILVA Data de Julgamento: Jul.: 07/05/2004)".

Por fim, então, conclui o Parquet pela constitucionalidade da Lei Municipal n. ${ }^{\circ} 8.896 / 02$, conhecida por "lei das antenas":

"É certo que estamos diante de uma legislação municipal que regula direito urbanístico, de saúde e ambiental, estando conforme à Carta Magna. (...)

Assim sendo, verifica-se que a Lei Municipal n. ${ }^{\circ} 8.896 / 02$ trata de matéria de interesse local, urbanística, de saúde pública e do meio ambiente, não contrariando a Constituição Federal, pelo que não se vislumbram vícios de constitucionalidade.

Pelo exposto, opina o PROCURADOR-GERAL DE JUSTIÇA DO ESTADO DO RIO GRANDE DO SUL no sentido de que seja julgada improcedente a presente arguição de inconstitucionalidade."

Assim, diante do exposto pelo Procurador-Geral de Justiça do Estado do Rio Grande do Sul e dos outros argumentos apresentados, conclui-se também pela constitucionalidade da Lei municipal n. ${ }^{\circ}$ 8.896/02, de Porto Alegre, que nos parece não invadir competência constitucional, mas, sim, regular questões específicas quanto à instalação das antenas de telefonia (ERBs), atendendo aos interesses locais e visando a tutelar os direitos individuais e coletivos de modo mais amplo e completo.

Finalmente, outro modo de obter a diminuição da exposição da radiação foi pela propositura de uma Ação Civil Pública por uma associação de moradores de São Paulo contra a empresa ELETROPAULO.

O Tribunal de Justiça do Estado de São Paulo foi favorável à pretensão da associação autora, determinando a diminuição da radiação do campo eletromagnético referente as linhas de transmissão de energia elétrica próximas a dois 
bairros paulistanos, sob argumento do potencial cancerígeno da radiação. Assim, foi determinado que o limite máximo de radiação deveria corresponder ao valor máximo de 1 microtesla (medida da radiação emitida pelas linhas de transmissão).

Diante disso, a ELETROPAULO interpôs Recurso Extraordinário contra referido acórdão, de modo que o processo encontra-se atualmente no Supremo Tribunal Federal (RExt $n^{\circ}$ 627.189). O Ministro Relator Dias Toffoli deu provimento ao pedido liminar para suspender a decisão até o julgamento do recurso pelo Supremo. Também foi reconhecida a repercussão geral do caso, pois a decisão a ser proferida irá repercutir na esfera de interesse de inúmeras pessoas.

E como a discussão da matéria envolve questão técnica, o Supremo Tribunal Federal houve por bem convocar audiências públicas nos dias 6, 7 e 8 de março de 2013, na sala de sessões da $1^{\text {a }}$ turma do STF, quando foram ouvidos 21 representantes de empresas e órgãos públicos ligados ao setor energético, entidades da sociedade civil e autoridades da área médica e ambiental.

Os profissionais da área deram maiores subsídios aos Ministros do Supremo Tribunal Federal, de modo que no momento aguarda-se o julgamento final deste caso, no qual o órgão de cúpula do Poder Judiciário decidirá a respeito da possibilidade de serem criados maiores limites à exposição da radiação eletromagnética. Certamente referida decisão influenciará as futuras decisões a respeito das ações de inconstitucionalidade das leis municipais que restringem a emissão da radiação em suas localidades, especialmente no aspecto da constitucionalidade material de referidas leis.

Assim, passada a apresentação e análise dos casos exemplificativos, é necessário reiterar a complexidade da discussão sobre a constitucionalidade das leis municipais a respeito do meio ambiente. Os que discordam dessa competência legislativa dos Municípios argumentam que ela não está explicitada na Constituição. Por outro lado, os que concordam argumentam que a Constituição atribuiu aos Municípios competência legislativa para o tratamento das questões locais, de modo suplementar à União e aos Estados. E, assim, estaria implícita a competência para elaboração de leis ambientais mais protetivas, sobretudo porque o ente municipal também está incumbido de defender e preservar o meio ambiente para as presentes e futuras gerações. Ponderam, ainda, que o Município é o lugar onde os cidadãos realmente vivem a sua história concreta e cotidiana, e, desse modo, a proximidade dos problemas possibilita condições mais propícias para a 
elaboração de leis ambientais visando ao meio ambiente ecologicamente equilibrado e à sadia qualidade de vida para todos. 


\section{CONCLUSÃO}

O tema desta dissertação trata da discussão sobre a competência dos Municípios para editarem leis a respeito do meio ambiente. Para o desenvolvimento da pesquisa, foram realizadas diversas considerações.

Primeiro, foi feita uma reflexão a respeito da nova ordem constitucional de 1988, que trouxe um novo regramento a respeito da repartição de competências entre os entes federados, cujo estudo se mostrou importante para se aferir a possibilidade do Município editar leis sobre meio ambiente.

Para entender como se deu a distribuição de competências na Constituição Federal de 1988, primeiramente, foi realizada uma breve síntese a respeito da organização do estado, do federalismo em geral e do federalismo brasileiro em particular.

Também se buscou, ainda no início da dissertação, verificar qual seria o conceito de competência no direito pátrio, assim como visualizar suas possíveis classificações, especialmente entre competência administrativa e legislativa. Ainda neste capítulo, foi verificada a existência de competências implícitas, as quais são extraídas do conjunto de dispositivos da Constituição.

Firmadas tais bases, passou-se ao estudo da competência ambiental propriamente dita, inclusive com o estudo do tratamento constitucional sobre o meio ambiente, os princípios norteadores da competência ambiental, assim como o papel da União e dos Estados nesta matéria.

Passada tal análise, foi possível o estabelecimento das bases constitucionais que fundamentam o tema central desta dissertação. Assim, foi dedicado um capítulo exclusivo para a análise da competência do ente municipal na legislação ambiental.

De início, entendeu-se necessário fazer um breve histórico a respeito da evolução da autonomia municipal na Federação. A partir de então, visualizou-se a competência material do Município, bem como sua competência legislativa. Nesse subcapítulo, que trata essencialmente do ponto fulcral da dissertação, foi feita uma análise atenta a respeito da edição de leis tratando do interesse local, bem como sobre a 
possibilidade de suplementação da legislação federal e estadual. Também se buscou verificar os limites materiais a respeito das leis municipais que tratam de meio ambiente, e, após, foram tecidas considerações a respeito das espécies de inconstitucionalidade das leis, assim como as especificidades do controle de constitucionalidade de leis municipais, tanto no controle concentrado como no difuso.

A partir de então, foram verificados casos representativos a respeito da controvérsia central. Inicialmente, foram narradas as inúmeras Ações Diretas de Inconstitucionalidades contra as leis municipais que proibiram a queima da palha da canade-açúcar, especialmente no interior do Estado de São Paulo. Diante da abrangência de ações e de declarações de votos pelos Desembargadores que julgaram tais casos, foi possível uma verificação ampla da linha de argumentação dos magistrados, tanto daqueles que entenderam que o Município não possuía competência para legislar a respeito do assunto, como também daqueles que decidiram que o Município não só tinha competência como teria agido bem na proteção do meio ambiente local.

Após, foi visto o emblemático caso da proibição das sacolas plásticas pelo comércio local, lei esta que ficou conhecida e acabou sendo repetida em inúmeros Municípios e Estados de todo o Brasil. Interessante notar que referido caso passou a ser objeto de discussão não só no meio jurídico, mas também pela sociedade em geral, inclusive tendo sido bastante noticiado pela imprensa.

De igual relevo se mostrou o caso da proibição do amianto, que foi discutida pelos membros da mais alta corte do Poder Judiciário brasileiro. Em que pese não tenha havido o julgamento final de tal caso, a decisão da Medida Cautelar correspondente já foi suficiente para demonstrar os posicionamentos expressos de cada Ministro do Supremo Tribunal Federal. A importância deste caso ficou ainda mais evidenciada por ter havido uma mudança no posicionamento do Pretório Excelso. Até então, as leis proibitivas eram sempre declaradas inconstitucionais, no entanto, os Ministros afirmaram expressamente que mudaram seus posicionamentos, de modo que passaram a aceitar a constitucionalidade da norma mais restritiva, ainda que em confronto com a lei federal permissiva.

Além desse caso, outro no qual foi aceita a constitucionalidade da lei mais restritiva foi a da Lei da Cidade Limpa. Foram criadas restrições na publicidade exposta na cidade de São Paulo, com vistas a sanar o problema da poluição visual que era comum até então. Outra lei relacionada ao meio ambiente urbano foi a da proibição do 
consumo de tabaco em ambientes fechados. Ambas buscaram melhorar a qualidade de vida das pessoas que vivem no meio ambiente urbano, e foram muito bem recepcionadas pela grande maioria da população local.

Tratando especificamente de cidades litorâneas, as quais em regra já possuem mais espaços territoriais que devem ser especialmente protegidos, foi analisada a constitucionalidade de um Município criar uma lei prevendo uma taxa de preservação ambiental. Diante da grande quantidade de turistas que frequientam as cidades litorâneas, foi aceito em tal caso que os custos da preservação ambiental fossem cobrados também dessas pessoas.

Ainda tratando de Municípios afetados por degradação ambiental, foi analisada também a tentativa de proibição da extração de carvão mineral em certa localidade.

Finalmente, os dois últimos casos tratados estão diretamente relacionados ao princípio da precaução, pois tratam de riscos de danos ambientais, nos quais ainda não há comprovação científica cabal dos malefícios para o meio ambiente e para a saúde humana. Primeiro viu-se a edição de lei obrigando a rotulagem com alertas sobre a existência de organismos geneticamente modificados (transgênicos) nos produtos. Após, foi analisada a lei que criava maiores restrições para a proximidade das antenas de celulares e linhas de transmissão de energia. Em ambos os casos, a complexidade do debate é elevada em razão da falta de comprovação científica sobre os possíveis danos ambientais.

E a partir da análise individual de cada um desses casos, é possível visualizar toda a linha de argumentação dos posicionamentos divergentes (quando existentes) dos Desembargadores e Ministros.

Mostra-se interessante a percepção de que referidos magistrados fazem a análise da argüição da (in)constitucionalidade formal das leis ambientais editadas pelos Municípios sempre de modo conjunto com a (in)constitucionalidade material da mesma lei. Isso contribui para tornar a questão ainda mais complexa, devendo, portanto, ser realizada uma análise caso a caso.

E da análise geral dos casos tratados, tem-se verificado que as restrições e proibições em prol do meio ambiente feitas por lei municipal se mostram, em sua maioria, em harmonia com os ditames da Constituição Federal. Por vezes, a legislação 
local está materializando um pleito de seus munícipes em razão de um problema ambiental de interesse local. Assim, na maior parte dos casos analisados percebeu-se que a iniciativa legislativa do Município cumpriu com seu dever constitucional de proteção do meio ambiente ${ }^{170}$ e também com seu dever de assegurar o direito à saúde ${ }^{171}$ aos munícipes.

Como ambos os deveres devem ser cumpridos por todo o Poder Público, mostra-se importante que o ente municipal também dê sua contribuição, atuando ao lado dos entes estaduais e federais, e com foco nos interesses de sua localidade.

Mencionando mais uma vez a doutrina de Paulo de Bessa Antunes, verifica-se uma síntese do que tem sido defendido a respeito dessa comunhão de esforços:

"A União pode desempenhar um importante papel ao capacitar os Estados e Municípios para o desempenho local das tarefas (...). não desconheço que a opção pela descentralização encerra toda uma série de dificuldades; contudo, parece-me ser o único caminho possível para que possamos, de uma só vez, aumentar a proteção ambiental, economizar recursos e, principalmente, diminuir o déficit democrático de nosso federalismo". ${ }^{172}$

Assim, a impressão que se tem é a de que somente poderá ser alcançada a adequada tutela do meio ambiente se houver a conjugação de esforços da União, dos Estados e Municípios na salvaguarda ambiental. Dessa forma, a União deveria assegurar os patamares nacionais mínimos de proteção do meio ambiente, enquanto os Estados e Municípios devem suplementar tais leis aumentando a restrição federal, sempre que vislumbrarem a necessidade de melhor protegerem seus respectivos interesses.

Tem-se percebido que a maior parte da legislação ambiental desenvolvida pelos Municípios está contribuindo para uma nova percepção a respeito do pacto federativo brasileiro, o qual tem cada vez mais prestigiado a autonomia local, especialmente quando se busca alcançar os direitos constitucionalmente assegurados, a exemplo do meio ambiente ecologicamente equilibrado.

E em havendo controvérsia num determinado caso concreto, as partes atingidas poderão se valer das Ações Declaratórias de Inconstitucionalidade, de forma que caberá ao Poder Judiciário a resolução do litígio. E como referidas ações sempre

\footnotetext{
${ }^{170}$ Artigo 225 da Constituição Federal.

${ }_{171}$ Artigo 196 da Constituição Federal.

${ }^{172}$ ANTUNES, Paulo de Bessa. Op. cit. p. 325.
} 
são julgadas por órgãos colegiados de cúpula do Poder Judiciário, estarão assegurados os mais enriquecedores debates a respeito do tema.

Se não bastasse, em alguns dos casos mencionados, o Supremo Tribunal Federal deu oportunidade para que a sociedade civil fosse ouvida diretamente, por meio das audiências públicas. Como exemplo, só neste ano de 2013 já houve audiências públicas sobre poluição eletromagnética das redes elétricas, bem como sobre a queima da palha da cana-de-açúcar.

A utilização de referido instrumento jurídico certamente servirá para a democratização da discussão, ampliando o debate a respeito de tais casos. Independentemente da decisão que vier a prevalecer em cada caso concreto, será importante verificar os fundamentos jurídicos dos votos dos Ministros, os quais certamente abordarão os temas da autonomia dos entes locais e sua correspondente competência legislativa, assim como a necessidade de proteção do meio ambiente e da saúde da população.

Em razão da pendência do julgamento de muitos dos casos mencionados, assim como pela infindável possibilidade de edição de novas leis ambientais pelos Municípios, mostra-se importante o contínuo acompanhamento do tema, tanto pela doutrina especializada, como também pelos Tribunais, os quais sempre são instados a decidirem concretamente cada um dos litígios surgidos.

Revela-se também significativa a continuidade das pesquisas no meio acadêmico a respeito do tema, por sua relevância na relação entre a Universidade e a sociedade, no que concerne à ampliação e preservação dos direitos fundamentais da cidadania, especialmente em relação ao meio ambiente ecologicamente equilibrado e à sadia qualidade de vida, tanto para as presentes como para as futuras gerações. 


\section{BIBLIOGRAFIA}

ALMEIDA, Fernanda Dias Menezes de. A repartição de competências na Constituição brasileira de 1998. Tese de doutoramento à Faculdade de Direito da Universidade de São Paulo sob orientação do Prof. Manoel Gonçalves Ferreira Filho. 1991.

ALMEIDA, Fernanda Dias Menezes de. Competências na Constituição de 1998. $5^{\text {a }}$ edição. São Paulo: Atlas, 2010.

ALVES, Alaôr Caffé. Meio ambiente e a questão metropolitana. In: Alaôr Caffé Alves; Arlindo Philippi Jr; Marcelo de Andrade Roméro; Gilda Collet Bruna. (Org.). Meio Ambiente, Direito e Cidadania. 1 $^{\mathrm{a}}$ ed. São Paulo: SIGNUS / NISAM-USP, v.1, 2002.

ANTUNES, Paulo de Bessa. Federalismo e competências ambientais no Brasil. Rio de Janeiro: Lúmen Júris Editora. 2007.

BELTRÂO, Antônio Figueiredo Guerra. A competência dos Estados federados em meio ambiente a partir da ordem constitucional de 1988. Brasília: Revista de informação legislativa do Senado Federal, n 159, ano 40, julho/setembro 2003.

BONAVIDES, Paulo. Curso de direito constitucional. 24a edição. São Paulo: Malheiros. 2009.

BRATZ, Jusara Aparecida. Competência do município para legislar em matéria ambiental à luz do princípio da subsidiariedade. Belo Horizonte: Revista interesse público, $\mathrm{n}^{\circ} 67$, ano XIII, maio/junho 2011.

BRUNA, Gilda Collet. Meio Ambiente urbano e proteção ambiental. In: Alaôr Caffé Alves; Arlindo Philippi Jr; Marcelo de Andrade Roméro; Gilda Collet Bruna. (Org.). Meio Ambiente, Direito e Cidadania. $1^{a}$ ed. São Paulo: SIGNUS / NISAM-USP, v.1, 2002.

CANOtillho, J. J. Gomes. Direito Constitucional e Teoria da Constituição. $7^{\mathrm{a}}$ ed. Portugal - Coimbra: Ed. Almedina, 2003. 
CAMARGO, A. Federalismo cooperativo e o princípio da subsidiariedade: notas sobre a experiência recente do Brasil e da Alemanha. In: HOFMEISTER, W., CARNEIRO, J. M. B. (Orgs.). Federalismo na Alemanha e no Brasil, Série Debates, n.22, v.1. São Paulo: Fundação Konrad Adenauer, 2001.

CAPEZ, Fernando; ROSA, Márcio Fernando Elias; CHIMENTI, Ricardo Cunha e SANTOS, Marisa Ferreira dos. Curso de direito constitucional. 2a edição. São Paulo: Saraiva, 2005.

CASTRO, José Nilo de. Direito Municipal Positivo. Belo Horizonte: Editora del Rey. 2006.

COELHO, Luiz Fernando. A competência concorrente em direito ambiental. Brasília: Revista de informação legislativa do Senado Federal, nº 114, ano 29, abril/junho 1992.

CORTEZ, Ana Tereza C.; ORTIGOZA, Silvia Aparecida G. (Org.). Da produção ao consumo - impactos socioambientais no espaço urbano. São Paulo: Editora UNESP. 2009.

CUSTÓDIO, Helita Barreira. Competência legislativa e combate ao amianto em defesa da saúde e do meio ambiente saudável. Belo Horizonte: Ed. Fórum. Revista fórum de direito urbano e ambiental, $n^{\circ} 43$, ano 8, janeiro/fevereiro 2009.

DALLARI, Dalmo de Abreu. Elementos de teoria geral do Estado. 24.ed Sã Paulo: Saraiva, 2003.

DALLARI, Dalmo de Abreu. Meio Ambiente e Município. In: Alaôr Caffé Alves; Arlindo Philippi Jr; Marcelo de Andrade Roméro; Gilda Collet Bruna. (Org.). Meio Ambiente, Direito e Cidadania. $1^{a}$ ed. São Paulo: SIGNUS / NISAM-USP, v.1, 2002.

DANTAS, Paulo Roberto de Figueiredo. Direito Constitucional. $6^{\text {a }}$ edição. São Paulo: Atlas. 2010.

FARIAS, Paulo José Leite. Competência Federativa e Proteção Ambiental. Porto Alegre: Sergio Antonio Fabris Editor. 1999.

FERRAZ Jr, Tércio Sampaio. Normas gerais e competência concorrente - uma exegese do art. 24 da Constituição Federal. São Paulo: Malheiros, Revista trimestral de direito público, $\mathrm{n}^{\circ} 7.1994$. 
FERRAZ, Sérgio Valladão. Curso de direito constitucional. Rio de Janeiro: Elsevier. 2007.

FERREIRA FILHO, Manoel Gonçalves. Curso de Direito Constitucional. São Paulo: Saraiva, 1992.

FIORILLO, Celso Antonio Pacheco. Curso de direito ambiental brasileiro. $10^{\mathrm{a}}$ edição. São Paulo: Saraiva. 2009.

GRECO, Leonardo. Competências constitucionais em matéria ambiental. Brasília: Revista de informação legislativa do Senado Federal, nº 116, ano 29, outubro/dezembro 1992.

GUIMARÃES, Juliana Pita. Competência constitucional dos Municípios em matéria ambiental. In COUTINHO, Ronaldo; ROCCO, Rogério. O Direito Ambiental das Cidades. Rio de Janeiro: Lumen Juris, 2009.

LENZA, Pedro. Direito constitucional esquematizado. 16a edição.São Paulo: Saraiva. 2012.

LEUZINGER, Márcia Dieguez; CUREAU, Sandra. Direito Ambiental. Rio de Janeiro: Elsevier Editora, 2008.

LOPES FILHO, Juraci Mourão. Competências Federativas - na Constituição e nos precedentes do STF. Salvador: Juspodivm, 2012.

MACHADO, Paulo Affonso Leme. Direito ambiental brasileiro. São Paulo: Malheiros. 2009.

MATTOS NETO, Antonio José de. Competência legislativa municipal sobre meio ambiente. Rio de Janeiro: Revista de direito administrativo, $\mathrm{n}^{\circ} 214$, outubro/dezembro 1998.

MEIRELLES, Hely Lopes. Direito Municipal brasileiro. $15^{\mathrm{a}}$ edição, atualizada por Márcio Schneider Reis e Edgard Neves da Silva. São Paulo: Malheiros. 2006.

MESSA, Ana Flávia. Direito Constitucional. São Paulo: Rideel. 2010.

MILARÈ, Edis. Direito do ambiente: a gestão ambiental em foco: doutrina, jurisprudência, glossário. São Paulo: Revista dos Tribunais. 2009. 
MORA, J. Ferrater. Dicionário de Filosofia - definição domínio. São Paulo: Loyola. 1994.

MOREIRA NETO, Diogo de Figueiredo. A competência legislativa e executiva do Município em matéria ambiental. Brasília: Revista de informação legislativa do Senado Federal, no 111, ano 28, julho/setembro 1991

RICHTER, Melvin. The Political Theory of Montesquieu. Estados Unidos: Cambridge University Press, 1977.

RUIZ-FABRI, Hélène. A adoção do princípio da precaução pela OMC in VARELLA, Marcelo Dias e PLATIAU, Ana Flávia Barros (Orgs). Princípio da Precaução. Belo Horizonte: Del Rey, 2004.

SAMPAIO, Rômulo Silveira da Rocha. Direito ambiental - doutrina e casos práticos. Rio de Janeiro: Elsevier Editora. 2012.

SILVA, José Afonso da. Curso de direito constitucional positivo. São Paulo: Malheiros Editores. 30ª edição. 2008.

SOUZA, Luiz Henrique Boselli de. Controle de constitucionalidade da norma municipal. Dissertação de mestrado à Faculdade de Direito da Universidade de São Paulo sob orientação do Prof. Sérgio Resende de Barros. 2006.

SOUZA, Motauri Ciocchetti de. Interesses Difusos em Espécie. $2^{\circ}$ Ed. São Paulo: Saraiva, 2009.

STUMP, Daniela. Conflito de competência legislativa ambiental: evolução da visão do STF sobre a regulação do amianto crisotila. São Paulo: Ed. Revista dos Tribunais. Revista de direito ambiental, $\mathrm{n}^{\circ} 58$, ano 15, abril/junho 2010.

VARELLA, Marcelo Dias. Variações sobre um mesmo tema: o exemplo da implementação do princípio da precaução pela CIJ, OMC, CJCE e EUA in VARELLA, Marcelo Dias e PLATIAU, Ana Flávia Barros (Orgs). Princípio da Precaução. Belo Horizonte: Del Rey, 2004.

VASQUES, Denise C. Competências legislativas concorrentes: prática legislativa da União e dos Estados-membros e jurisprudência do Supremo Tribunal Federal. Dissertação de 
Mestrado à Faculdade de Direito da Universidade de São Paulo sob orientação do Prof. Elival da Silva Ramos. 2007.

Annex to document A/42/417. Report of the World Comission on Environment and Development: Our Common Future. General Assembly, UN. 1987. Disponível em: http://www.un-documents.net/wced-ocf.htm 